\title{
R Reactor Seepage Basins Soil Moisture and Resistivity Field Investigation Using Cone Penetrometer Technology, Savannah River Site, Aiken, South Carolina
}

by

M. K. Harris

Westinghouse Savannah River Company

Savannah River Site

Aiken, South Carolina 29808

J. V. Noonkester

This paper was prepared in connection with work done under the above contract number with the U.S.

Department of Energy. By acceptance of this paper, the publisher and/or recipient acknowledges the U. S.

Government's right to retain a nonexclusive, royalty-free license in and to any copyright covering this paper, along with the right to reproduce and to authorize others to reproduce all or part of the copyrighted paper. 
WSRC-TR-99-00330

Rev. 0

\section{R Reactor Seepage Basins Soil Moisture and Resistivity Field Investigation using Cone Penetrometer Technology, Savannah River Site, Aiken, South Carolina (U)}

Mary K. Harris, Jay V. Noonkester

September 1999

Prepared by:

Westinghouse Savannah River Company Savannah River Site

Aiken, SC 29808

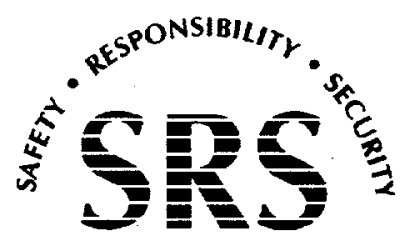

SAVANNAH RIVER SITE

Prepared for the U.S. Department of Energy Under Contract Number DE-AC09-96SR18500 


\section{DISCLAIMER}

This report was prepared as an account of work sponsored by an agency of the United States Government. Neither the United States Government nor any agency thereof, nor any of their employees, makes any warranty, express or implied, or assumes any legal liability or responsibility for the accuracy, completeness, or usefulness of any information, apparatus, product or process disclosed, or represents that its use would not infringe privately owned rights. Reference herein to any specific commercial product, process or service by trade name, trademark, manufacturer, or otherwise does not necessarily constitute or imply its endorsement, recommendation, or favoring by the United States Government or any agency thereof. The views and opinions of authors expressed herein do not necessarily state or reflect those of the United States Government or any agency thereof.

This report has been reproduced directly from the best available copy.

Available for sale to the public, in paper, from: U.S. Department of Commerce, National Technical Information Service, 5285 Port Royal Road, Springfield, VA 22161, phone: (800) 553-6847

fax: (703) 605-6900

email: orders@ntis.fedworld.gov

online ordering: http://www.ntis.gov/ordering.htm

Available electronically at http://www.doe.gov/bridge

Available for a processing fee to U.S. Department of Energy and its contractors, in paper, from: U.S. Department of Energy, Office of Scientific and Technical Information, P.O. Box 62, Oak Ridge, TN 37831-0062, phone: (865) 576-8401

fax: (865) 576-5728

email: reports@adonis.osti.gov 


\section{DISCLAIMER}

Portions of this document may be illegible in electronic image products. Images are produced from the best available original document. 


\section{R Reactor Seepage Basins Soil Moisture and Resistivity Field Investigation using Cone Penetrometer Technology, Savannah River Site, Aiken, South Carolina (U)}

Mary K. Harris, Jay V. Noonkester

September 1999

Prepared by:

Westinghouse Savannah River Company

Savannah River Site

Aiken, SC 29808

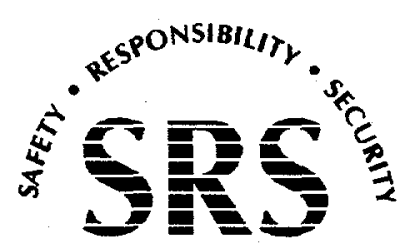

Prepared for the U.S. Department of Energy Under

Contract Number DE-AC09-96SR18500 
R Reactor Seepage Basins Soil Moisture and Resistivity Field Investigation using Cone Penetrometer Technology, Savannah River Site, Aiken, South Carolina

Authentication and Approvals:

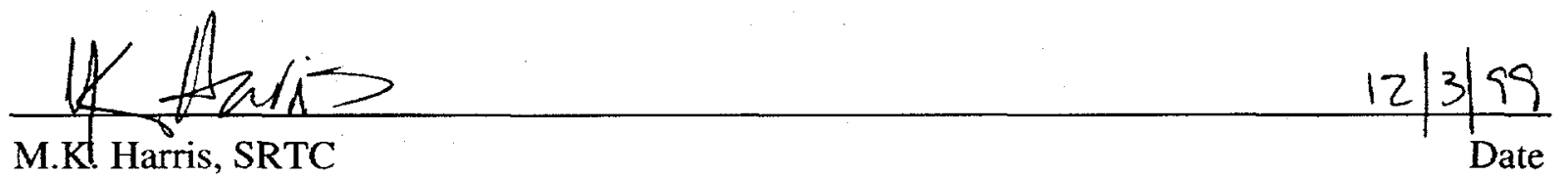

M.K! Harris, SRTC
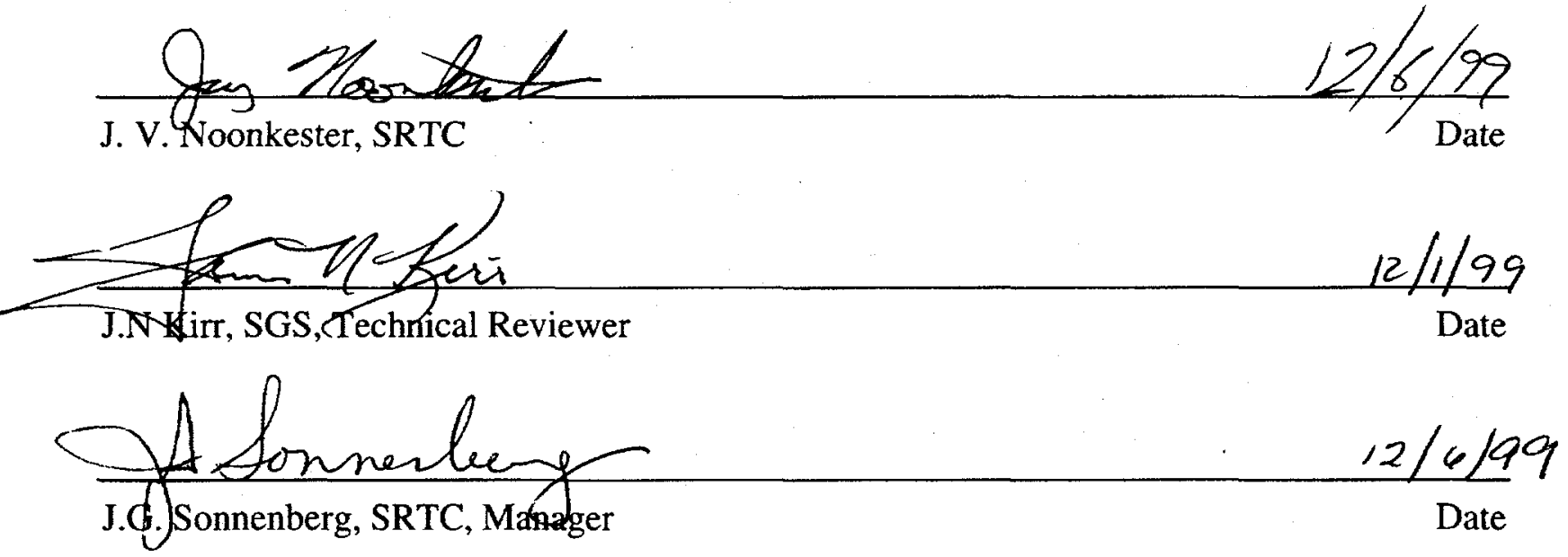


\section{EXECUTIVE SUMMARY}

Recent and historical water table levels at the R Reactor Seepage Basins (RRSBs) suggest that a "perched" water table may exist directly beneath the RRSBs based on regulatory documentation and groundwater modeling. Additional studies were conducted in the summer of 1999 of the shallow groundwater system to determine if the water beneath the RRSBs is actually perched or whether the shallow water table is in direct communication with the underlying "transmissive zone". Direct Push or Cone Penetrometer Technology (CPT) was used to investigate the shallow water table beneath the basins. CPT soil moisture and resistivity tests combined with CPT lithologic data (tip, sleeve, friction ratio, and pore pressure) were performed at 10 locations. The CPT pushes were pushed to approximately 105 ' to obtain a saturation profile from the surface to the top of the "transmissive zone" in the Upper Three Runs Aquifer. Shelby tube samples were taken with the soil moisture analysis to validate and confirm moisture percentage.

Upon completion of the field investigation the following sources of data were integrated to determine the characteristics of the shallow water table:

- CPT data (moisture \%, resistivity data, pore pressure, tip, sleeve, and friction ratio)

- Permeability data

- Water level and potentiometric data to determine head relations

- Contaminant Data

All the data indicate that perched water conditions occur on a seasonal basis during extremely wet periods as were experienced in the spring of 1998 . There is significantly less mounding of the water table beneath the RRSBs with water levels being 10-15 feet lower during 1999 . This is due to the "draining" of the upper water table due to dry conditions in the summers of both 1998 and 1999 along with the effects of the asphalt cover over the basins. CPT data further indicates that the 1998 water levels were located on top of silty and clayey layers in March 1998. In addition, the confining-like characteristics of the "A" and "AA" horizons and the positive potentiometric surface of the underlying "Transmissive" zone impede vertical movement of groundwater from the surface to the "transmissive zone". This interpretation is corroborated by the extent of Sr-90 contamination in the upper water table DU zone and the absence of Sr-90 contamination in the lower DL ("transmissive" zone). Therefore, contamination from the Principal Threat Source Material (PTSM) associated with the RRSBs will not easily migrate into the underlying "transmissive zone". 
This page intentionally left blank 


\section{Table of Contents}

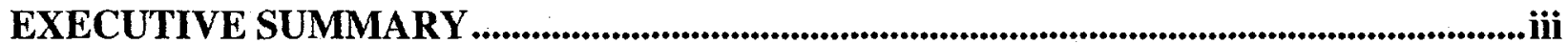

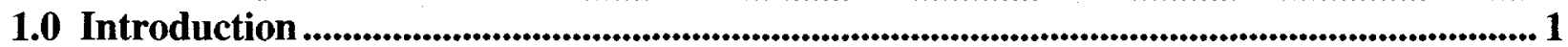

1.1 Hydrogeology and Extent of Contamination ........................................................... 1

1.2 Field Characterization Methodology using the Cone Penetrometer Soil Moisture \&

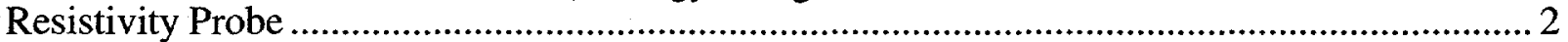

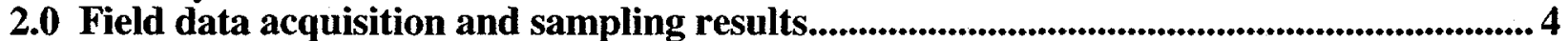

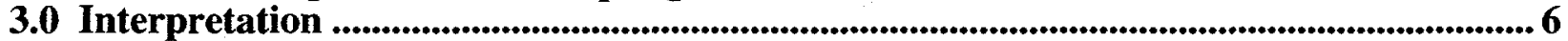

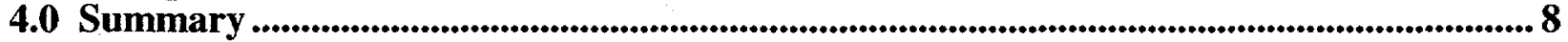

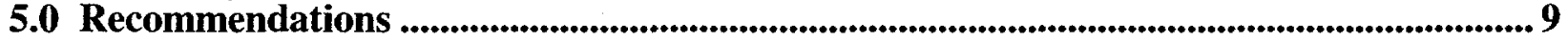

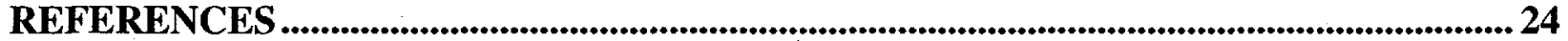




\section{List of Tables and Figures}

Table 1: Name and locations of the RR CPTs 3

Table 2: Laboratory Results from RR-3, RR-7, and RR-9 ..................................................................5

Figure 1: Location of the R Reactor Seepage Basins within R Reactor Area. ........................................... 11

Figure 2: Conceptual Hydrogeologic Diagram for the R Reactor Seepage Basins .................................... 12

Figure 3: Water Table Map - DU screen zone - March 1998, Contour Interval = 5 Ft. ....................... 13

Figure 4: Transmissive zone Potentiometric Surface - DL screen zone - March 1998, Contour Interval = 5 Ft.

Figure 5: Soil Moisture Probe CPT Locations 15

Figure 6: Areal Extent of Contamination illustrating 2 CPT pushes inside fenced area 16

Figure 7: CPT RR-03 illustrating Friction Ratio, Pore Pressure, Resistivity, and Volume \% moisture with March 1998 and June 1999 water levels from the DU and DL screens of Well RPC-1

Figure 8: CPT RR-07 illustrating Friction Ratio, Pore Pressure, Resistivity, and Volume \% moisture with March 1998 and June 1999 water levels from the DU and DL screens of Well RPC-1

Figure 9: CPT RR-09 illustrating Friction Ratio, Pore Pressure, Resistivity, and Volume \% moisture with March 1998 and June 1999 water levels from the DU and DL screens of Well RPC-1

Figure 10: East-West Cross-Section with CPT RR-09, RR-19A, RR-3 illustrating volume \% moisture and resistivity CPT curves with March 98 and June 99 DU and DL water elevations plotted. Traverse for cross-section is located on Figure 5 .

Figure 11: Three-dimensional grid of volume percent moisture. Yellow and red area indicate saturated zone.

Figure 12: Water Table Map - DU screen zone - June 1999, Contour Interval = 5 Ft. 22

Figure 13: Transmissive zone Potentiometric Surface - DL screen zone - June 1999, Contour Interval = 5 Ft. 


\subsection{Introduction}

Recent and historical water table levels at the R Reactor Seepage Basins (RRSBs) (Figure 1) suggest that a "perched" water table may exist directly beneath the basins. Recent regulatory documentation (WSRC, 1998) and groundwater modeling (Jones and others, 1998) both indicated that additional study of the shallow groundwater system is needed to determine if the water beneath the RRSBs is actually perched or whether the shallow water table is in direct communication with the underlying "transmissive zone". The understanding of the shallow water table in relation to the hydrology of the area is essential for the ongoing feasibility study for the waste unit. Whether or not the water table is perched may impact the remedial alternative selection for the Principal Threat Source Material (PTSM). If the water table is "perched", then it is part of the soil column above the "Transmissive zone" (which would become the first viable aquifer zone). If this is the case soil leachability would be considered from the contaminant source to the "transmissive zone for the purpose of remedial technology selection". The focus of this report is the summer 1999 investigation of the shallow groundwater system using cone penetrometer technology (CPT) characterization methods to determine if the water table is perched beneath the RRSBs.

The characterization plan for this study was documented in a Workplan Addendum outlining additional field characterization for the RRSB Workplan/RFI/RI for the RRSB (WSRC, 1999a).

\subsection{Hydrogeology and Extent of Contamination}

There are four hydrostratigraphic units that are important to contaminant migration. Figure 2 is a conceptual hydrogeological model for the RRSB area. The seepage basins are located in undifferentiated surface soils of varying thickness. The "A" and "AA" horizons immediately beneath the seepage basins, and correspond to the Upland Unit and Tobacco Road Formation. The "A" and "AA" horizons both are similar to confining units with relatively low hydraulic conductivities (average $1.0 \times 10^{-7} \mathrm{~cm} / \mathrm{sc}$ and $1.0 \times 10^{-6} \mathrm{~cm} / \mathrm{sec}$, respectively). The "Transmissive" zone underlies the "AA" horizon, and correlates to the Irwinton Sand of the Dry Branch Formation. This zone has relatively high hydraulic conductivity averaging $1.0 \times 10^{-4} \mathrm{~cm} / \mathrm{sec}$.

Groundwater is present in the " $\mathrm{A}$ " and "AA" horizons and the "Transmissive" zone. The hydraulic characteristics of the "A" and "AA" horizons are not well understood because these strata behave more like confining units than aquifers. The vertical mobility of the 
groundwater within these low permeability units is also not well understood. Figure 2 illustrates how the groundwater in the "A" and "AA" (DU) horizons is at similar head to the potentiometric surface of the "Transmissive" zone (DL) to the west of the waste units. This is supported by the water table surface of the "A/AA" and potentiometric surface of the "Transmissive" zone (Figures 3 and 4). In the area underlying the RRSBs the groundwater surface associated with the "Transmissive" zone (DL) drops toward the "Old" R Area Discharge Canal, which indicates the aquifer discharges into the canal. However, in the same area the water table surface associated with the "A/AA" horizon (DU) is relatively flat lying when compared to the "Transmissive" zone (DL) which suggests minimal connection between the two water bearing units.

The majority of the Contaminants of Concern (COCs) associated with PTSM have not migrated significantly within the vadose zone, and tend to remain within the contaminated soils in the backfilled basins. However, a portion of the Sr-90 associated with the PTSM, has migrated to the groundwater within the "A" horizon. Am-241, Pu239/240 are also contaminant migration constituent of concern (CMCOCs) are therefore predicted to migrate from the PTSM to the groundwater at activities above their respective maximum contaminant level (MCL). The potential for migration of contaminants in the groundwater within the " $\mathrm{A}$ " horizon, to deeper stratigraphic units, is dependent upon the connection between the water bearing units. Therefore it is very important to have a good understanding of the hydraulic characteristics of these hydrostratigraphic units, and the degree of connectivity of the units, to make good predictions of contaminant transport. In addition, this information is critical to a proper selection of remedial alternatives.

\subsection{Field Characterization Methodology using the Cone Penetrometer Soil Moisture \& Resistivity Probe}

Soil Moisture Probes were evaluated at the Savannah River Site in 1996 and 1997 (Argonne National Laboratory, 1997) through the Site Characterization and Analysis Penetrometer System. The soil moisture probe is used in conjunction with direct push technology to obtain real-time data to measure subsurface volumetric soil moisture. Shelby tube samples are taken with the soil moisture analysis to validate and confirm moisture percentage. In addition, resistivity $\log$ profiles were used in conjunction with the soil moisture percentage measurements. Based on prior studies conducted at the SRS, the soil moisture percentages increase as the probe approaches the saturated zone, while the resistivity decreases with the 
increase in water in the pore space of the sediments (WSRC, 1999, Argonne National Labs, 1997).

CPT soil moisture and resistivity tests combined with CPT lithologic data (tip, sleeve, friction ratio, and pore pressure) were performed at 10 locations (Figure 5 and Table 1). The CPT pushes were pushed to approximately $105^{\prime}$ through the undifferentiated surface soils, "A" Horizon and "AA" Horizon to obtain a saturation profile from the surface to the top of the "transmissive zone" in the Upper Three Runs Aquifer. The CPT pushes were terminated at the top of the "Transmissive zone". Two of the CPT pushes (RR-19A and 19-B) were inside the RRSB fence (Figure 5), and required RCO/HP coverage. The locations within the RRSB fenced area were chosen based on the RRSB RFI/RI characterization work that delineated the extent of contamination (Figure 6). The locations are in non-contaminated areas within the fence (Figure $5 \& 6$ ).

The remaining 8 pushes were completed outside the fence and did not require $\mathrm{RCO} / \mathrm{HP}$ coverage (Figure 5). All of the locations are being done near existing lithologic pushes to maximize hydrogeologic data in the area for interpretive purposes. Shelby tubes were collected at 3 locations for soil moisture percentage and porosity. Shelby tube samples were collected, sealed, and stored according to WRSC-3Q5.

\begin{tabular}{|c|c|c|c|}
\hline CPT ID & SRSE & SRSN & Elevation \\
\hline RR-19A & 75349.1 & 57966.3 & 306.63 \\
\hline RR-19B & 75534.1 & 57887 & 306.63 \\
\hline RR-3 & 75745.5 & 58111.6 & 305.7 \\
\hline RR-4 & 75727.98 & 58380.3 & 299.2 \\
\hline RR-5 & 75609 & 58798.8 & 301.4 \\
\hline RR-6 & 75115.7 & 58891.3 & 297.8 \\
\hline RR-7 & 74692.2 & 58785.6 & 299.1 \\
\hline RR-8 & 74657.5 & 58283.4 & 299.9 \\
\hline RR-9 & 74512.2 & 57895.8 & 297.6 \\
\hline RR-10 & 74538.6 & 57354 & 291.6 \\
\hline
\end{tabular}

Table 1: Name and locations of the RR CPTs 


\subsection{Field data acquisition and sampling results}

Field data acquisition began on 6/14/99 and ended on 7/1/99. Details of the daily activities are reported in Appendix A. Initially, electrical connection problems required repeating several of the pushes to ensure quality data was collected. Other than the electrical malfunctions, the remaining field work went smoothly. Appendix B contains plots of the 10 pushes with sleeve and tip stress, friction ratio, pore pressure, resistivity, and volume percent moisture plotted.

Shelby Tube Samples were collected at RR-3, RR-7, and RR-9. Table 2 summarizes the results. Figures $7-9$ illustrates the sample locations and percentages in relation to the CPT data and June water levels at nearby RPC-3 DU and DL. Soil samples were taken in clear tubing in four foot sections. The samples were then examined to determine where to take the sample based on the CPT results and lithologic type. Samples were analyzed by LAW Engineering and Environmental Services in Atlanta, GA for Grain Sieve Wash 200 (ASTM D422) and volumetric soil moisture content, density and porosity (EM1110-2-1906). Appendix C provides the detailed results from LAW Engineering and Environmental Services.

Samples were taken at RR-3 beginning at a depth of 5 feet. A total of 10 samples were taken ending at 101.5 feet. Again, samples were taken based on the lithology and in relation to the response on the CPT moisture percentage curve (Figure 7). Generally, the results match well with the laboratory results and the predicted moisture from the CPT probe. In the upper 30 feet of RR-3 there is variability of approximately $15 \%$ moisture percentage in interbedded sandy, silty and clayey sediments. In the lower portion of RR-3 the moisture percentage is relatively stable with variability of approximately $10 \%$. 


\begin{tabular}{|c|c|c|c|c|c|c|c|c|c|}
\hline $\begin{array}{c}\text { Sample } \\
\text { ID }\end{array}$ & SRS E & SRS N & $\begin{array}{c}\text { Ground } \\
\text { Elev. }\end{array}$ & $\begin{array}{c}\text { Sample } \\
\text { Depth (ft.) }\end{array}$ & $\begin{array}{l}\text { Moisture } \\
\text { Content\% }\end{array}$ & $\begin{array}{c}\text { Wet } \\
\text { Density } \\
\text { pef }\end{array}$ & $\begin{array}{c}\text { Dry } \\
\text { Density } \\
\text { pcf }\end{array}$ & $\begin{array}{l}\text { Spec. } \\
\text { Gravity }\end{array}$ & Porosity \\
\hline RR-03- & 75745.5 & 58111.6 & 305.7 & $5.0-6.0$ & 9 & 101.4 & 93 & 2.66 & 0.44 \\
\hline RR-03- & 75745.5 & 58111.6 & 305.7 & $10.5-11.5$ & 15.4 & 117.7 & 102.1 & 2.68 & 0.39 \\
\hline RR-03- & 75745.5 & 58111.6 & 305.7 & $14.0-15.0$ & 6.3 & 109.9 & 103.5 & 2.62 & 0.37 \\
\hline RR-03- & 75745.5 & 58111.6 & 305.7 & $18.0-19$ & 20 & 113.8 & 94.9 & 2.66 & 0.43 \\
\hline RR-03- & 75745.5 & 58111.6 & 305.7 & $20.5-21.5$ & 22 & 113.1 & 92.7 & 2.68 & 0.45 \\
\hline RR-03- & 75745.5 & 58111.6 & 305.7 & $22.5-23.5$ & 22.7 & 118.1 & 96.3 & 2.68 & 0.42 \\
\hline RR-03- & 75745.5 & 58111.6 & 305.7 & $26.0-27.0$ & 18.6 & 116.0 & 97.8 & 2.71 & 0.42 \\
\hline RR-03- & 75745.5 & 58111.6 & 305.7 & $57.5-58.5$ & 20.4 & $\dagger 16.2$ & 96.5 & 2.64 & 0.41 \\
\hline RR-03- & 75745.5 & 58111.6 & 305.7 & $83.5-84.5$ & 29.9 & 115.2 & 88.6 & 2.61 & 0.46 \\
\hline RR-03- & 75745.5 & 58111.6 & 305.7 & $100.5-$ & 26.4 & 117.5 & 92.9 & 2.65 & 0.44 \\
\hline RR-07- & 74692.2 & 58785.6 & 299.1 & $3.0-4.0$ & 19.1 & 113.4 & 95.2 & 2.64 & 0.42 \\
\hline RR-07- & 74692.2 & 58785.6 & 299.1 & $11.0-12.0$ & 12.5 & 113.1 & 100.6 & 2.65 & 0.39 \\
\hline RR-07- & 74692.2 & 58785.6 & 299.1 & $13.5-14.5$ & 10.8 & 105.4 & 95.2 & 2.62 & 0.42 \\
\hline RR-07- & 74692.2 & 58785.6 & 299.1 & $16.5-17.5$ & 14.7 & 103.7 & 90.3 & 2.63 & 0.45 \\
\hline RR-07- & 74692.2 & 58785.6 & 299.1 & $18.0-19.0$ & 19.8 & 107.4 & 89.6 & 2.66 & 0.46 \\
\hline RR-07- & 74692.2 & 58785.6 & 299.1 & $22.0-23.0$ & 14.1 & 101.6 & 89.1 & 2.67 & 0.47 \\
\hline RR-09- & 74512.2 & 57895.8 & 297.6 & $6.0-7.0$ & 10.8 & 101.5 & 91.6 . & 2.65 & 0.45 \\
\hline RR-09- & 74512.2 & 57895.8 & 297.6 & $10.0-11.0$ & 16.3 & 117.2 & 100.8 & 2.66 & 0.39 \\
\hline RR-09- & 74512.2 & 57895.8 & 297.6 & $14.0-15.0$ & 27.7 & 110.5 & 86.5 & 2.68 & 0.48 \\
\hline RR-09- & 74512.2 & 57895.8 & 297.6 & $18.0-19.0$ & 19.1 & 112.4 & 94.4 & 2.65 & 0.43 \\
\hline RR-09- & $745+2.2$ & 57895.8 & 297.6 & $22.0-23.0$ & 18.3 & 115.4 & 97.6 & 2.66 & 0.41 \\
\hline RR-09- & 74512.2 & 57895.8 & 297.6 & $26.0-27.0$ & 16.9 & 116.7 & 99.9 & 2.65 & 0.4 \\
\hline
\end{tabular}

Table 2: Laboratory Results from RR-3, RR-7, and RR-9 
Samples were taken at RR-7 beginning at 3 feet. A total of 6 samples were taken ending at 23 feet. The agreement is good for the correlation between the laboratory values and CPT probe predictions for soil moisture. There is approximately $15 \%$ variability in the laboratory values in the highly interbedded sandy, silty, and clayey sediments in the upper 30 feet of RR-7. There is excellent correlation between the lithology defined by the friction ratio with the pore pressure response, resistivity and moisture percentage curves (Figure 8).

Samples were taken at RR-9 beginning at 6.0 feet. A total of 6 samples were taken ending at 27 feet. Again, agreement is relatively good for the correlation between the laboratory values and CPT probe predictions for soil moisture. The sediments are not as highly interbedded in RR-09 as in RR-03 and RR-07. This is reflected in the higher moisture percentage values around 15 feet. Correlation is good between the lithology defined by the friction ratio with the pore pressure response, resistivity and moisture percentage curves (Figure 9).

Figure 10 illustrates an east-west cross-section labeled $A-A^{\prime}$ (traverse location on Figure 5) through sample points RR-9, RR-19A, and RR-3. The cross-section also illustrates the water table DU elevations and the "Transmissive" zone potentiometric surface DL elevations in March 1998 and June 1999. This relation will be discussed in the next section.

Figure 11 is a 3-dimensional grid of the soil moisture probe data over the RRSB data. The grid illustrates that the lower percent moisture is near the surface in the surface soils and " $\mathrm{A}$ " horizon and the higher percent moisture is correlative with the elevation of the "Transmissive" zone potentiometric surface. The moisture percentage is relatively stable below this surface.

\subsection{Interpretation}

The purpose of the study was to determine if "perched" water conditions exist in the shallow water table system at the RRSBs. Upon completion of the soil moisture probe and resistivity study other data was combined to better resolve and understand the characteristics of the shallow hydrogeology.

The RPC wells that rim the RRSBs (Figure 5) were installed in March 1998. During installation the region experienced unusually heavy rains from the "El Nino" effect of Pacific Ocean heating. Upon completion of the well installation water table measurements indicated an extremely high water table surface, sometimes within 0.5 feet of the ground surface (Appendix D and Figure 3). The monthly water table measurements begun in August 1998 
continue to be collected. The water levels have dropped significantly since March 1998 . Appendix D contains the hydrographs for the RPC wells around the RRSBs. Figures $7-9$ illustrate the water level differences experienced from March 1998 until June 1999 at RPC3DU/RR-03, RPC-7DU/RR-07, and RPC-9DU/RR-09. At all three locations the water table has dropped significantly ranging from $10-15$ feet with very small differences currently observed between the upper DU "A/AA" horizon water table screen and the lower DL "transmissive" zone screen of $2-5$ feet.

Figures 3 and 4 and Figures 12 and 13 illustrate the March 98 and June 99 water table surface for the DU screens and DL screens, respectively. Notice, that there is significantly less mounding underneath the basins in June 99 for the upper water table surface in the DU screens. This is interpreted to be from the "draining" of the upper water table due to dry conditions that have been experienced in the summers of both 1998 and 1999 and the effects of the asphalt cover over the basins. The soil moisture probe data supports this interpretation. Figures 7 (RR-03) and 8 (RR-07) illustrate that in March 1998 the DU screen zone water levels were located on top of silty and clayey layers and therefore were exhibiting perched conditions during that timeframe. During 1999 the DU water levels have dropped and have stabilized with very little head separation between the DU \& DL water elevations. The DU water levels appears to have little effect on vertical groundwater movement. This is consistent with the vertical permeabilities and horizontal groundwater flow velocities cited in the August 1998 RFI/RI/BRA (WSRC, 1998). The average vertical permeability for the "A" horizon is $1.0 \times 10^{-6} \mathrm{~cm} / \mathrm{sec}$ and the annual horizontal movement is approximately 9.2 $\mathrm{cm} /$ year. This coupled with the positive head conditions of the underlying "transmissive zone" support the that the PSTM will not easily migrate into the underlying transmissive zone.

The soil moisture probe CPT data (volume moisture \%, resistivity data, pore pressure, tip, sleeve, and friction ratio) coupled with the water level data indicate strongly that perched water conditions occur on a seasonal basis during extremely wet periods as were experienced in March 1998. However, due to the confining like characteristics of the "A" and "AA" horizons and the positive potentiometric surface of the underlying "Transmissive" zone the vertical movement of groundwater from the surface to the "transmissive zone" is not likely. This interpretation is corroborated by the extent of Sr-90 contamination in the upper water table DU zone and the absence of Sr-90 contamination in the lower DL ("transmissive" zone) as reported in the RFI/RI/BRA (WSRC, 1998). 


\subsection{Summary}

Recent and historical water table levels at the RRSBs suggested that a "perched" water table may exist directly beneath the RRSBs based on regulatory documentation (WSRC, 1998) and groundwater modeling (Jones and others, 1998). Additional studies were conducted in the summer of 1999 of the shallow groundwater system to determine if the water beneath the RRSBs is actually perched or whether the shallow water table is in direct communication with the underlying "transmissive zone".

Direct Push Technology was used to investigate the shallow water table beneath the basins. CPT soil moisture and resistivity tests combined with CPT lithologic data (tip, sleeve, friction ratio, and pore pressure) were performed at 10 locations. The CPT pushes were pushed to approximately 105 ' through the undifferentiated surface soils, "A" Horizon and "AA" Horizon to obtain a saturation profile from the surface to the top of the "transmissive zone" in the Upper Three Runs Aquifer. Shelby tube samples were taken with the soil moisture analysis to validate and confirm moisture percentage.

Upon completion of the field investigation the following sources of data were integrated to determine the characteristics of the shallow water table:

- CPT data (volume moisture \%, resistivity data, pore pressure, tip, sleeve, and friction ratio)

- Permeability data

- Water level and potentiometric data to determine head relations

- Contaminant Data

All the data indicate that perched water conditions occur on a seasonal basis during extremely wet periods as were experienced in March 1998. There is significantly less mounding of the water table beneath the RRSBs with water levels being $10-15$ feet lower during 1999 . This is interpreted to be from the "draining" of the upper water table due to dry conditions in the summers of both 1998 and 1999 and the effects of the asphalt cover over the basins. Perched water is also indicated by the lithologic data. Careful examination of the CPT data and water level data illustrate the March 1998 DU screen water levels were located on top of silty and clayey layers in March 1998. 
Furthermore, the confining like characteristics of the "A" and "AA" horizons (based on permeability data) and the positive potentiometric surface of the underlying "Transmissive" zone impede vertical movement of groundwater from the surface to the "transmissive zone". This interpretation is corroborated by the extent of Sr-90 contamination in the upper water table DU zone and the absence of Sr-90 contamination in the lower DL ("transmissive" zone) as reported in the RFI/RU/BRA (WSRC, 1998). Therefore, contamination from the PTSM associated with the RRSBs will not easily migrate into the underlying "transmissive zone".

\subsection{Recommendations}

Monitoring of the R Area wells water elevations on a monthly basis should be continued. In addition, individual monitoring of selected wells should be initiated. Electronic instrumentation that can measure the water levels on a timed interval should be considered. This would allow for rain events to be monitored to verify the perching of water on the silty and clayey layers near the ground surface.

The new piezometers that were installed to monitor water levels near the R-Area Canal should be measured on a monthly basis. In addition, these wells should be considered for individual monitoring as well as described above.

Multi-well pumping tests are planned at the RPC-1 and P-20 cluster during FY00. The information from these tests should be integrated into the soil moisture/resistivity field characterization results to further understand the shallow hydrogeology and its relation to contaminant migration of the PTSM to the subsurface beneath the RRSBs. 
This page intentionally left blank. 


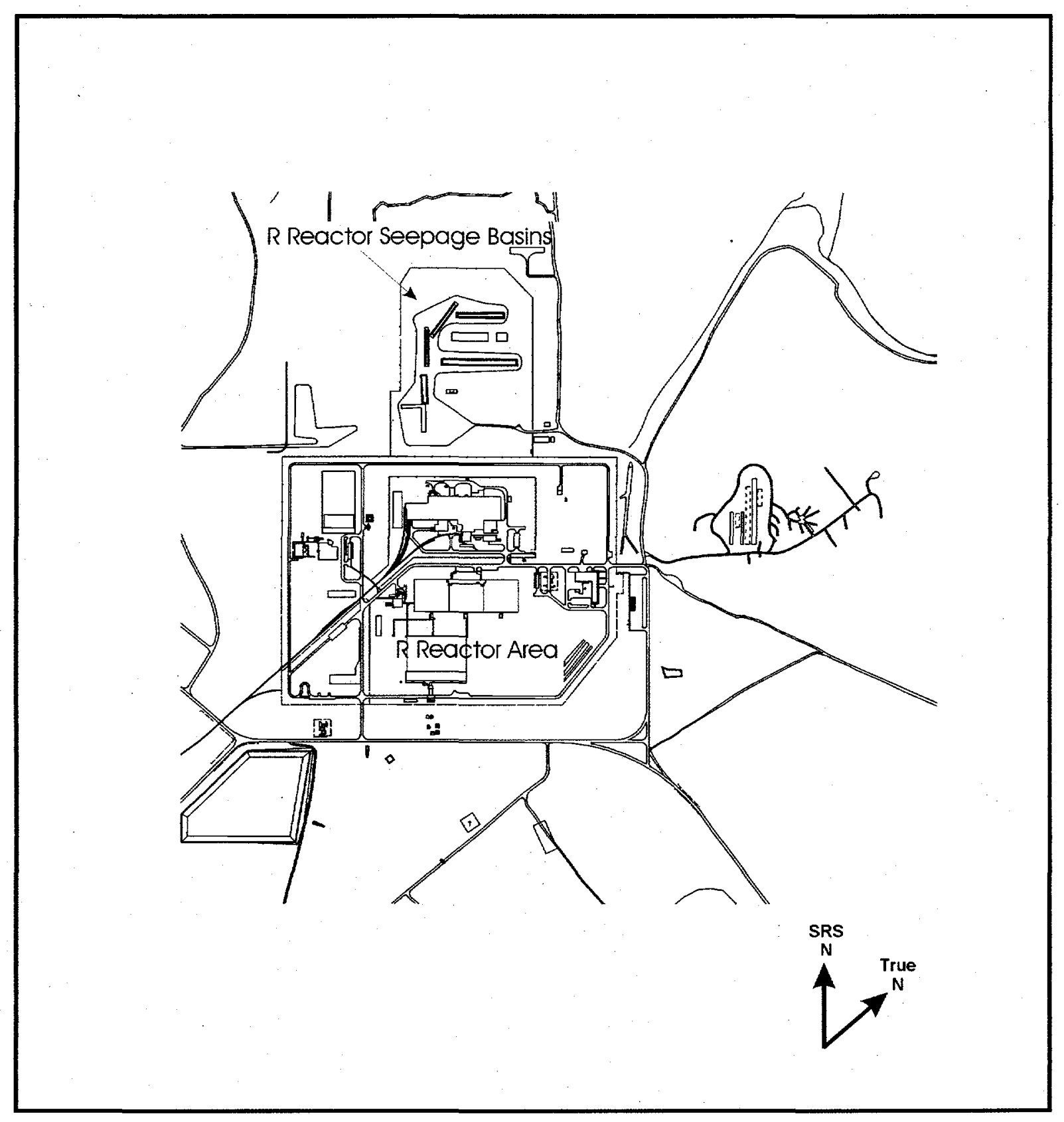

Figure 1: Location of the R Reactor Seepage Basins within R Reactor Area. 


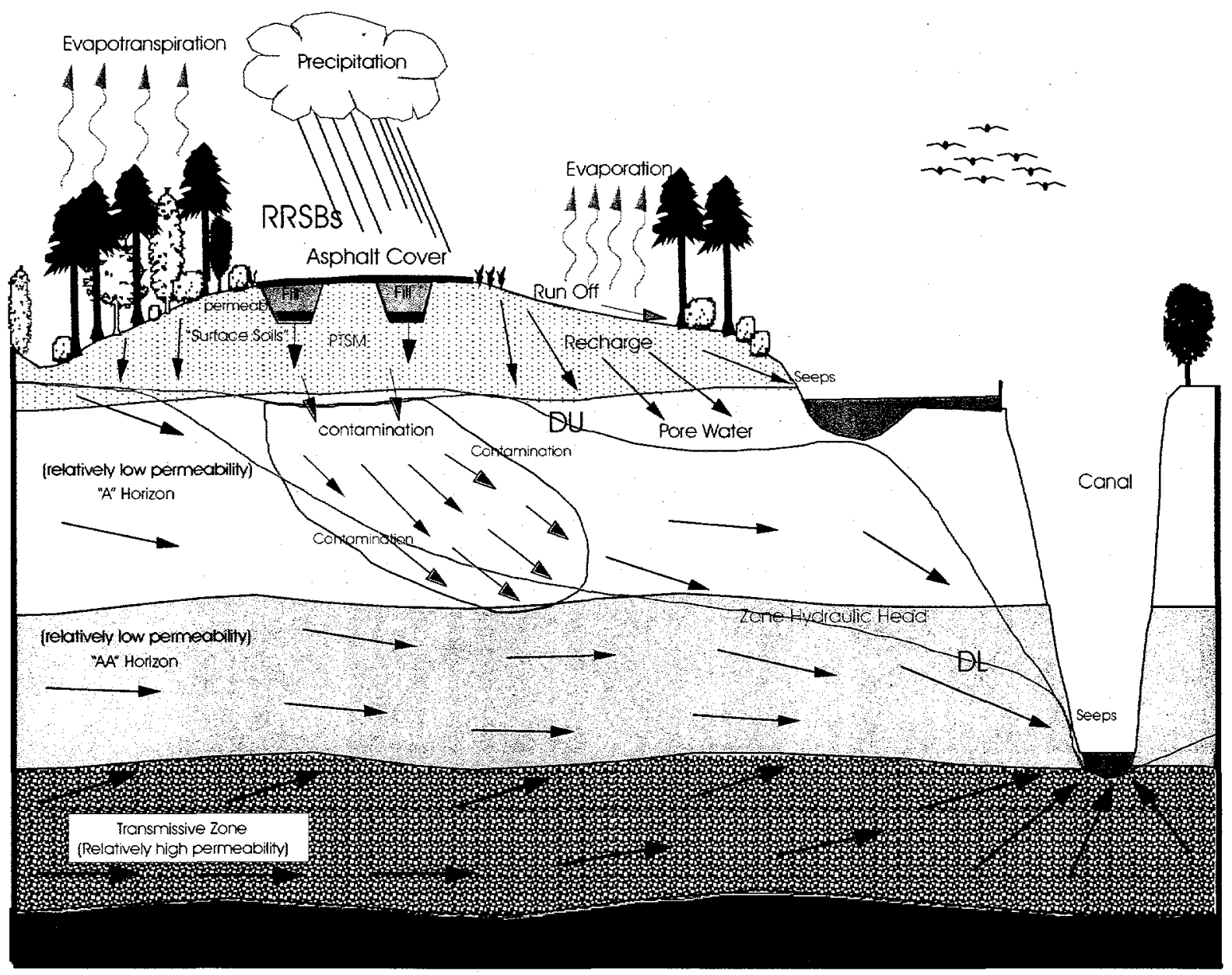

Figure 2: Conceptual Hydrogeologic Diagram for the R Reactor Seepage Basins 


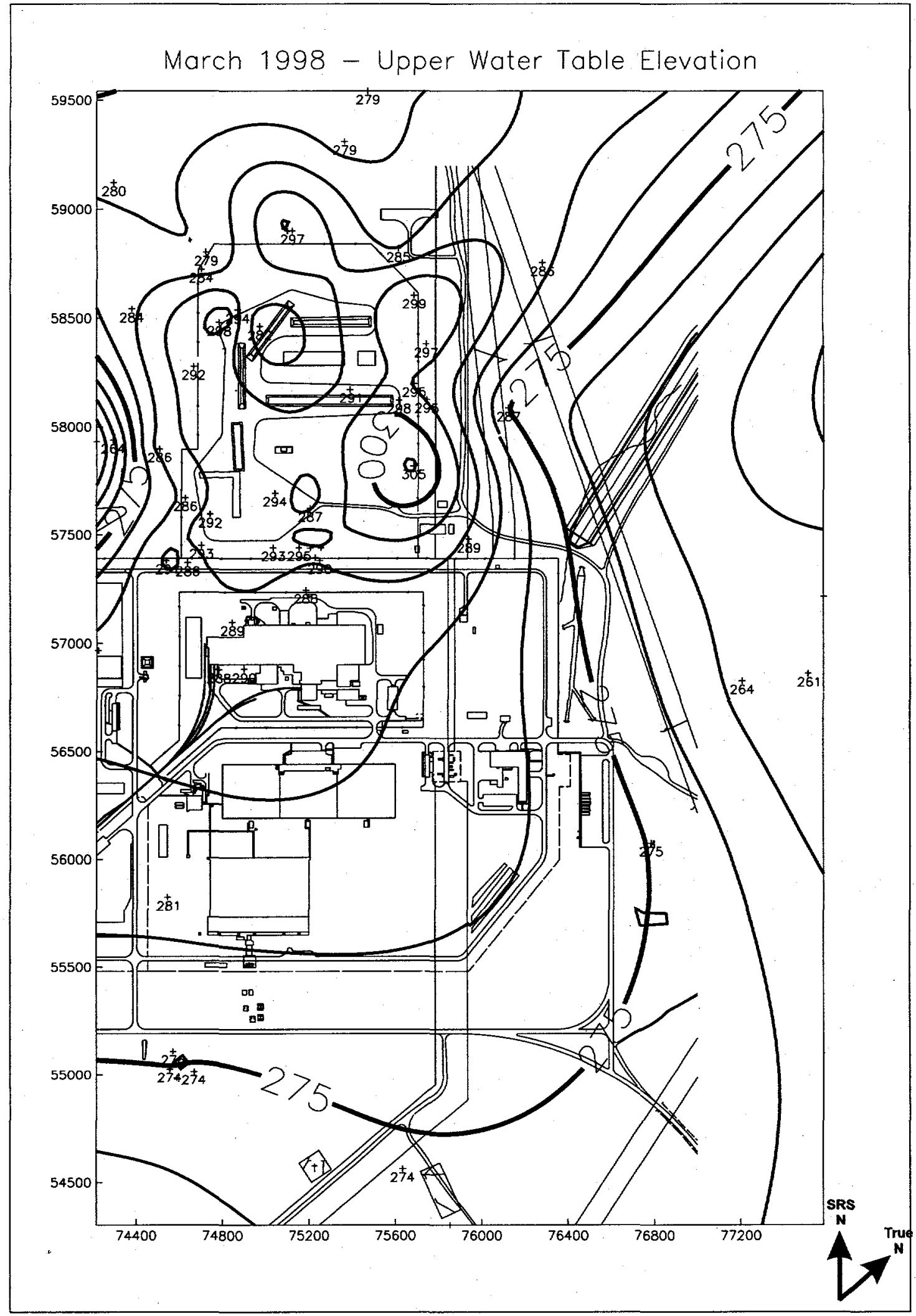

Figure 3: Water Table Map - DU screen zone - March 1998, Contour Interval = 5 Ft. 


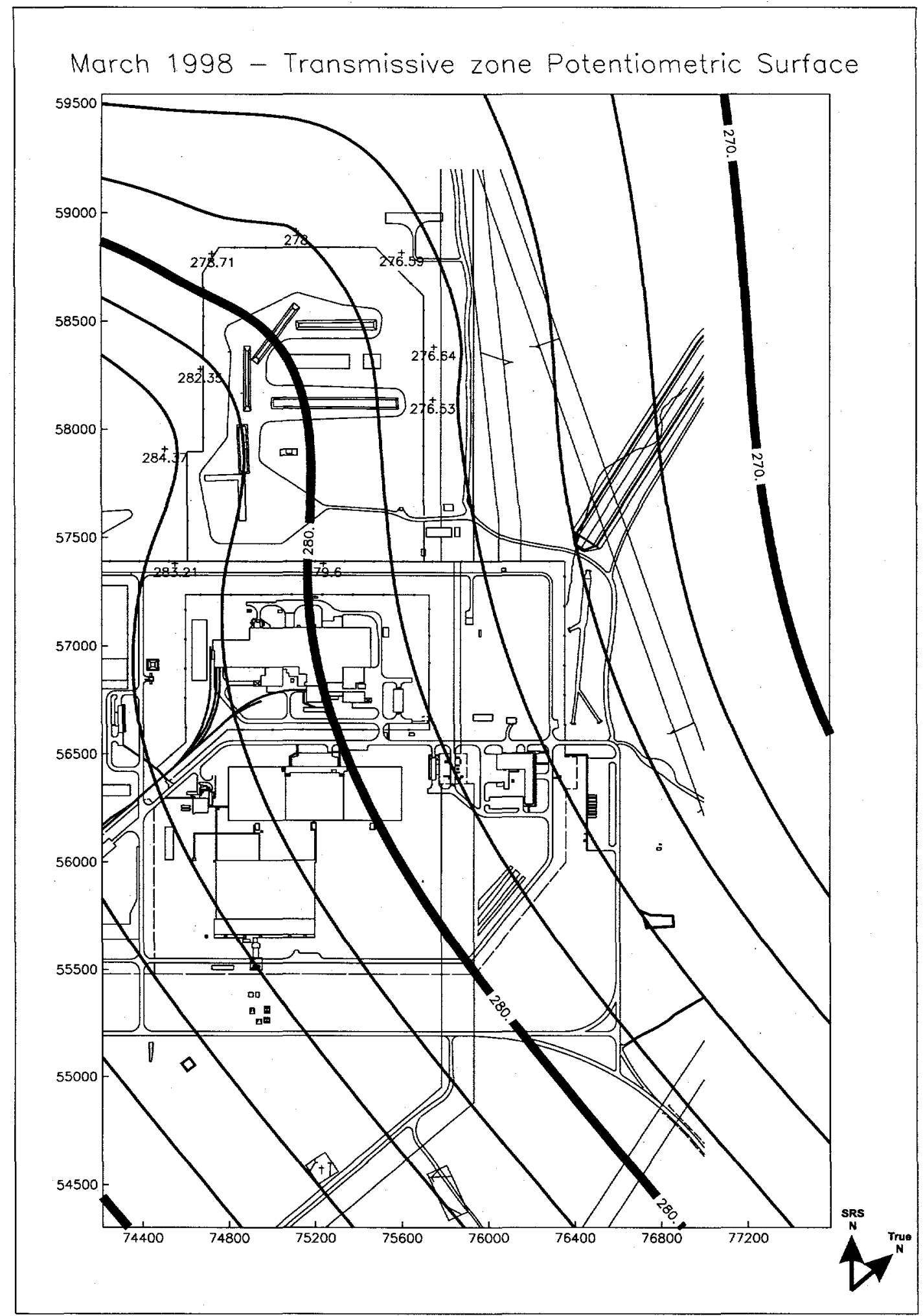

Figure 4: Transmissive zone Potentiometric Surface - DL screen zone - March 1998, Contour Interval $=5$ Ft. 


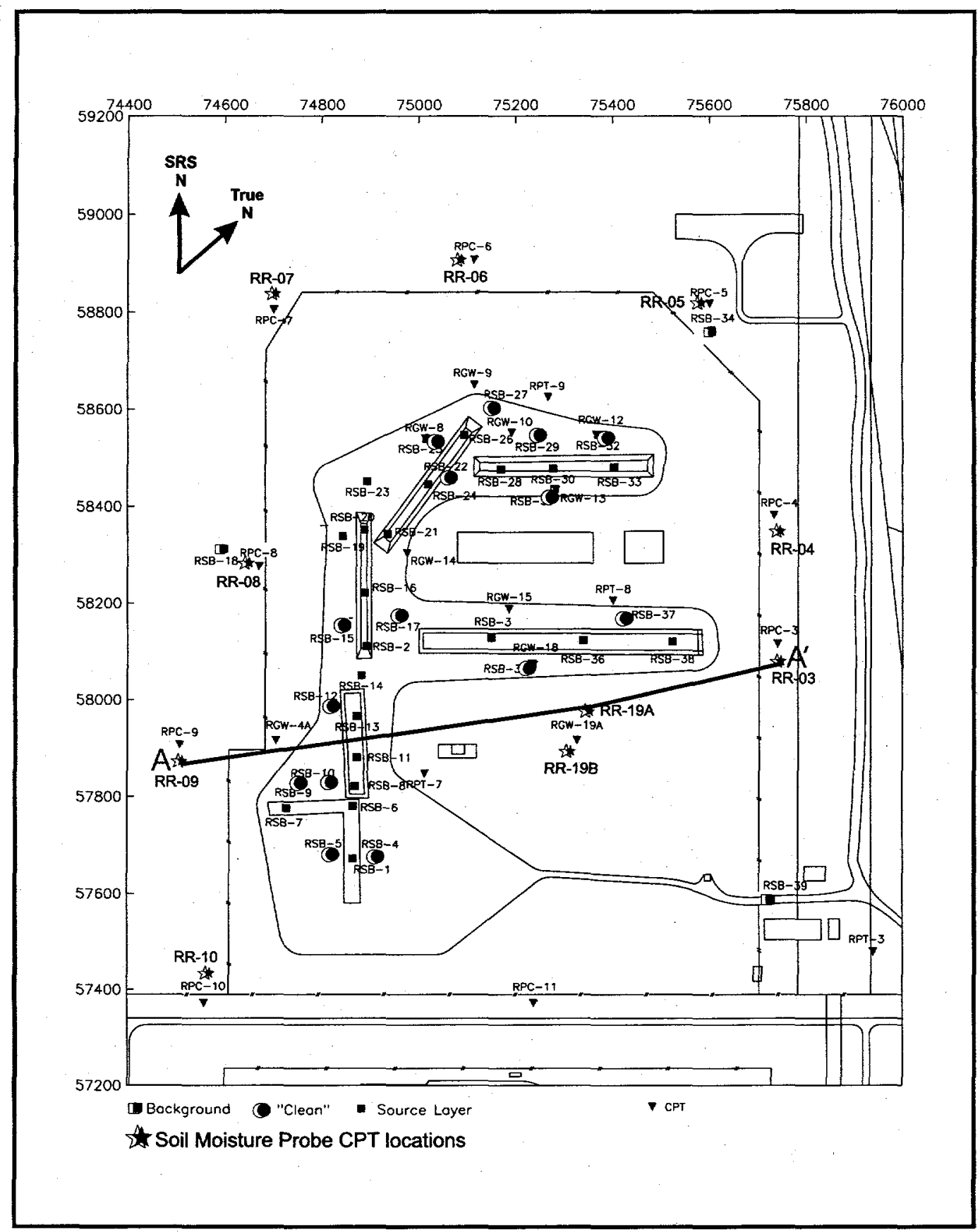

Figure 5: Soil Moisture Probe CPT Locations 

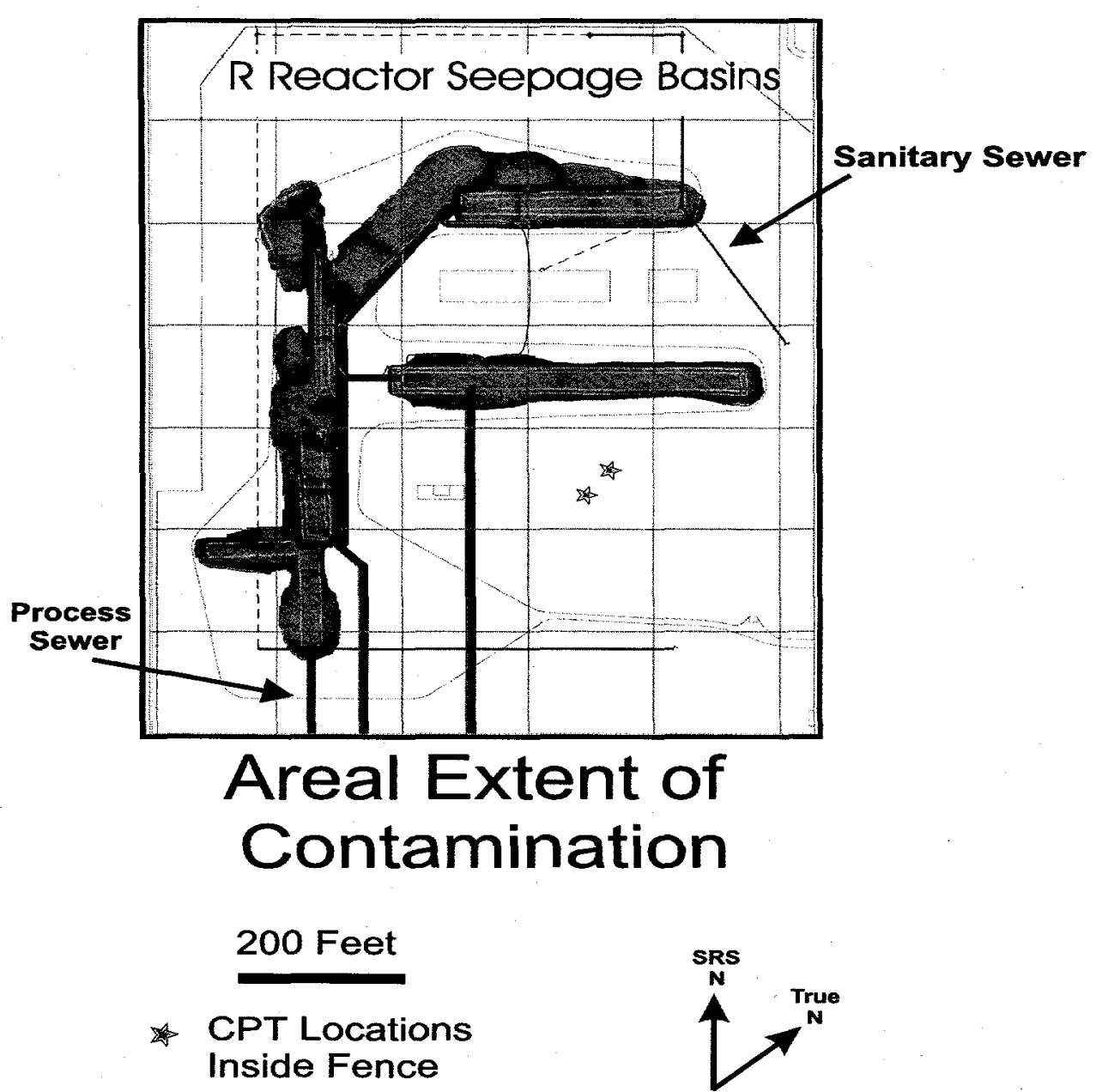

Figure 6: Areal Extent of Contamination illustrating 2 CPT pushes inside fenced area. 


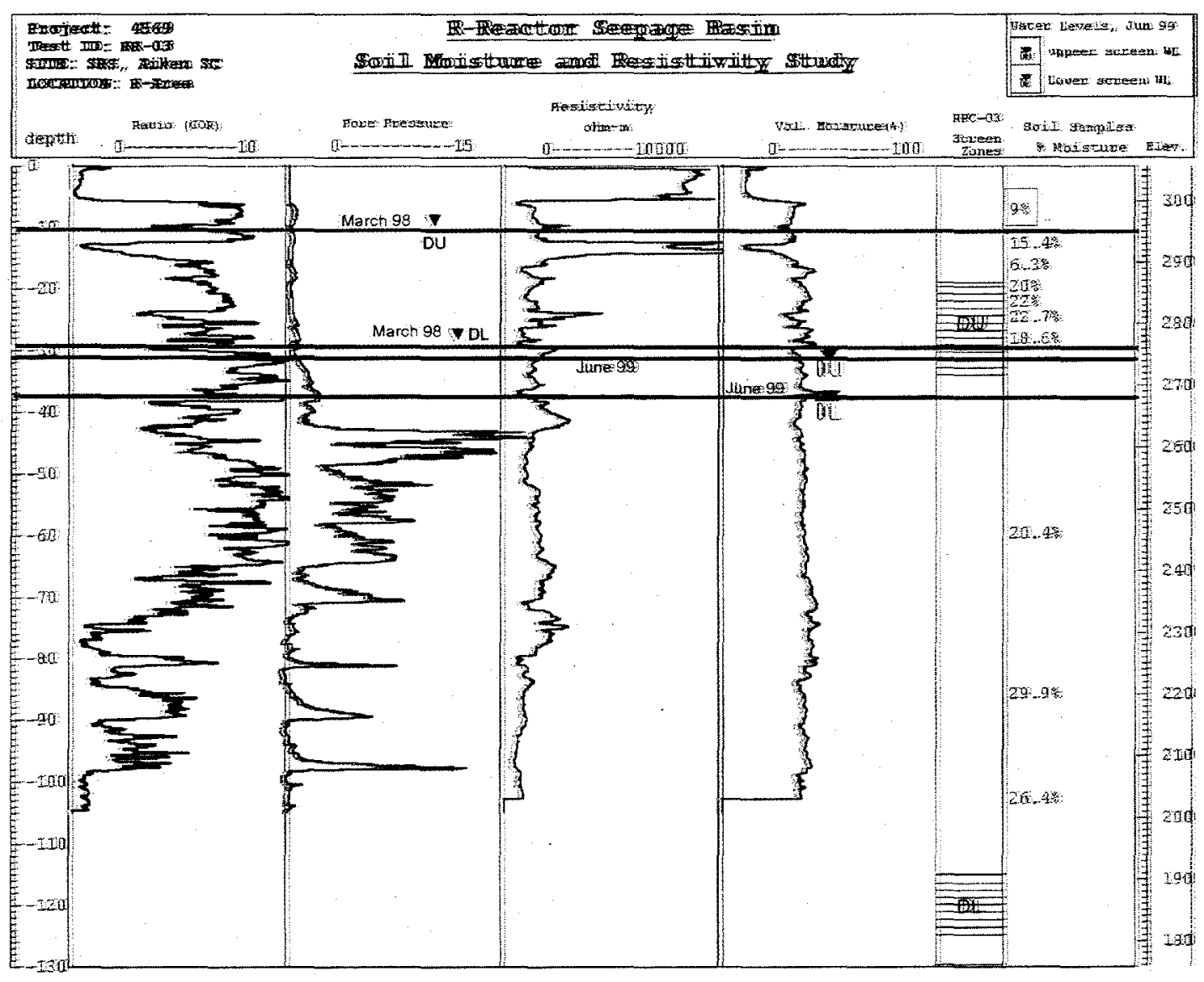

Figure 7: CPT RR-03 illustrating Friction Ratio, Pore Pressure, Resistivity, and Volume \% moisture with March 1998 and June 1999 water levels from the DU and DL screens of Well RPC-1 


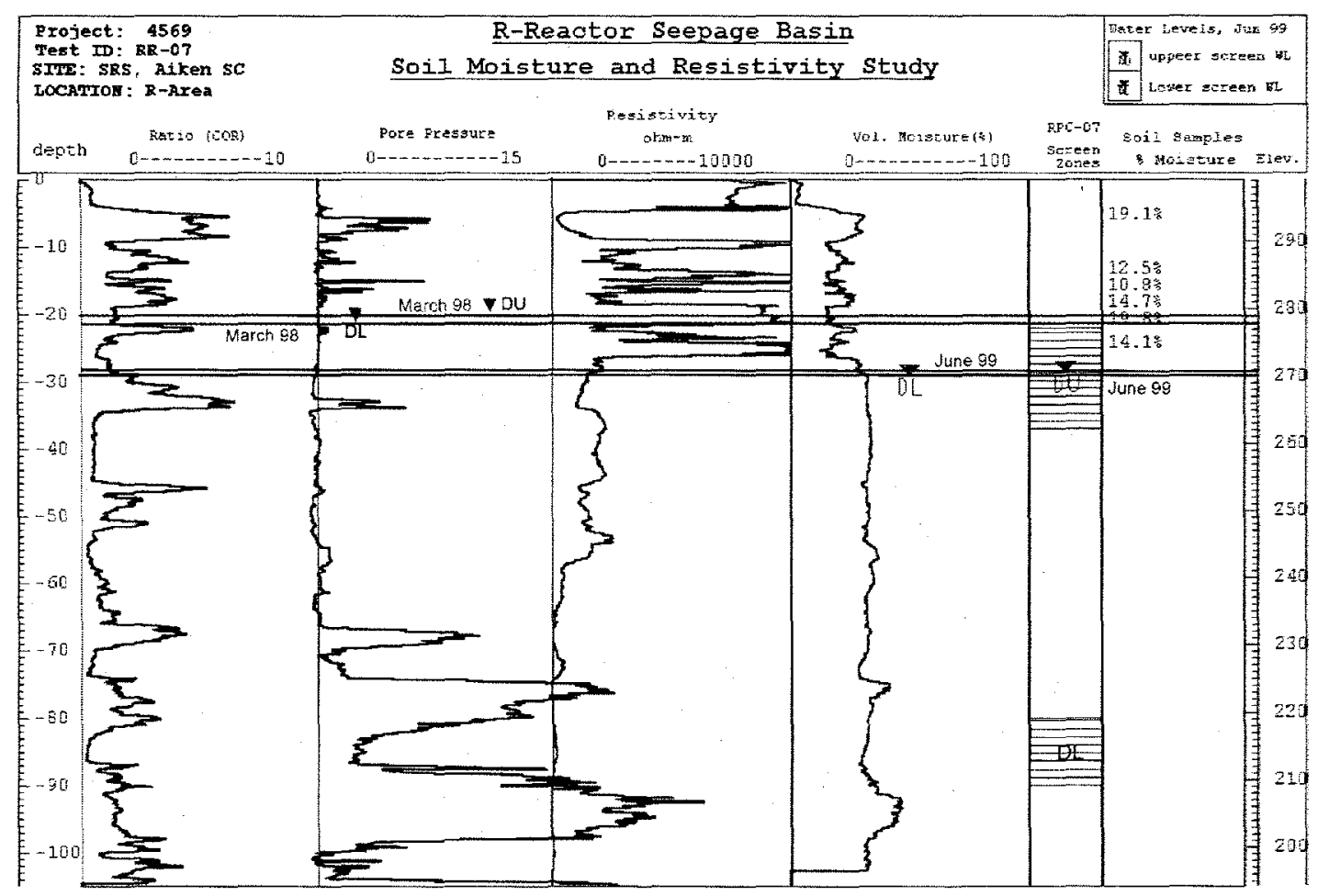

Figure 8: CPT RR-07 illustrating Friction Ratio, Pore Pressure, Resistivity, and Volume \% moisture with March 1998 and June 1999 water levels from the DU and DL screens of Well RPC-1 


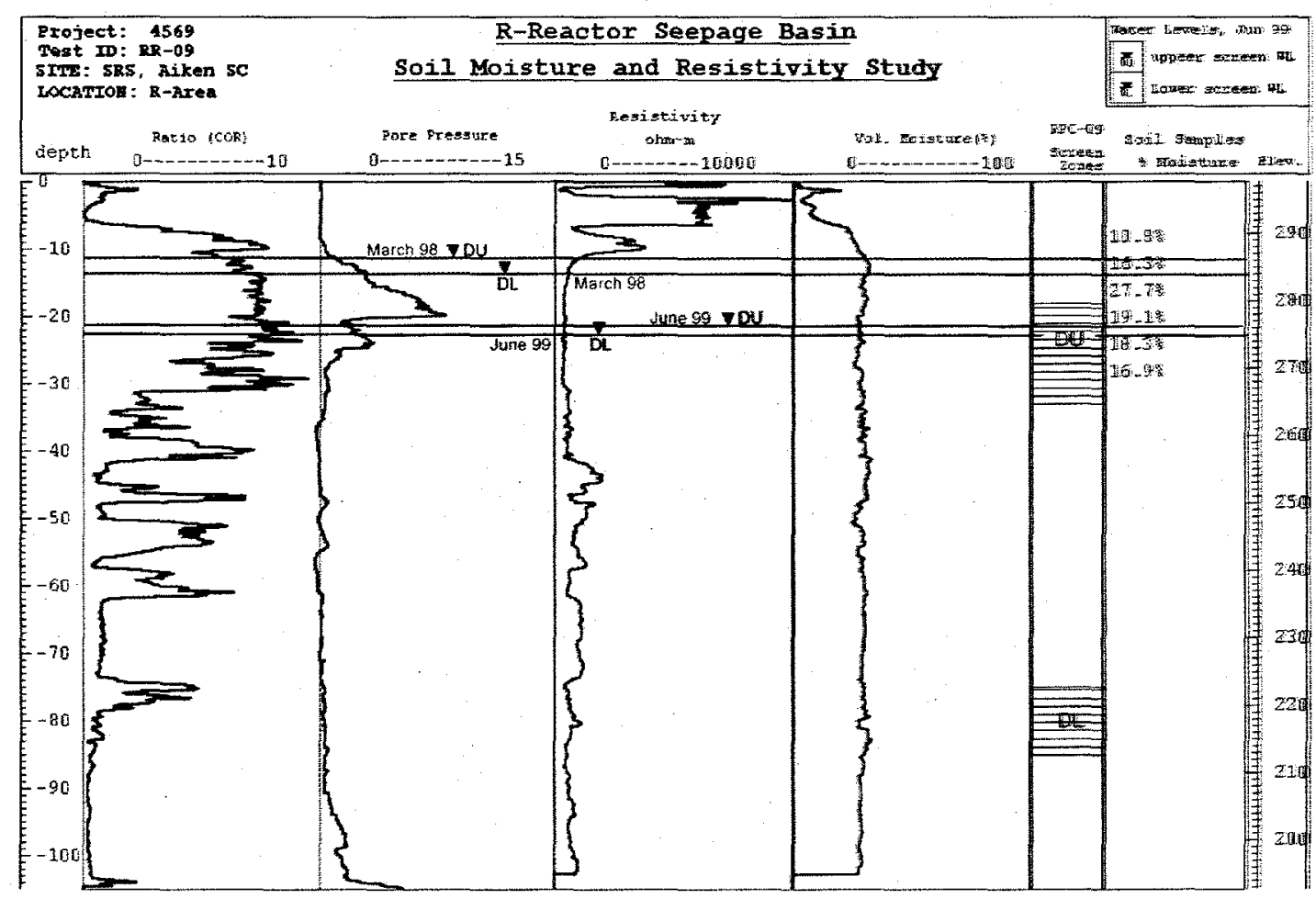

Figure 9: CPT RR-09 illustrating Friction Ratio, Pore Pressure, Resistivity, and Volume \% moisture with March 1998 and June 1999 water levels from the DU and DL screens of Well RPC-1 


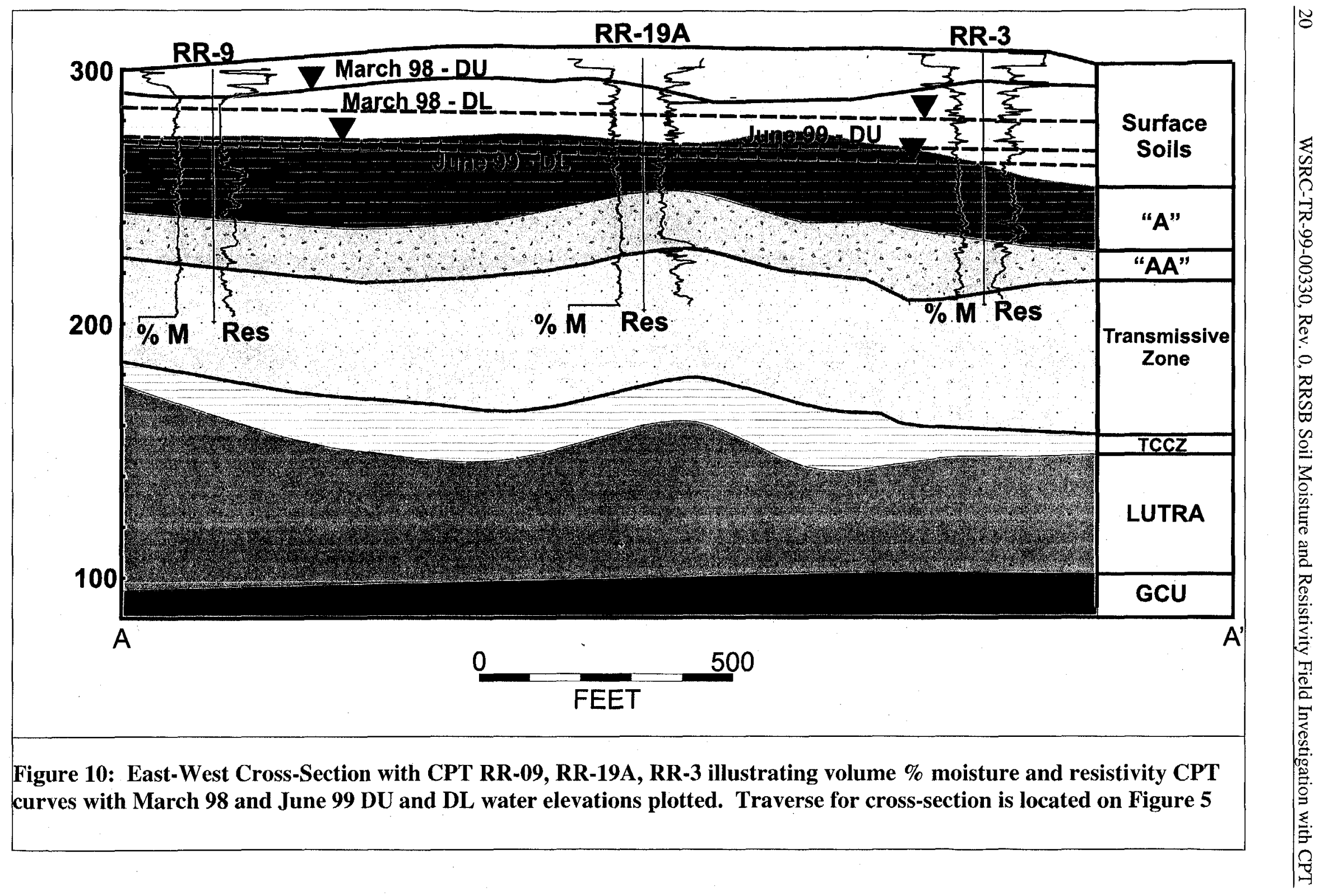




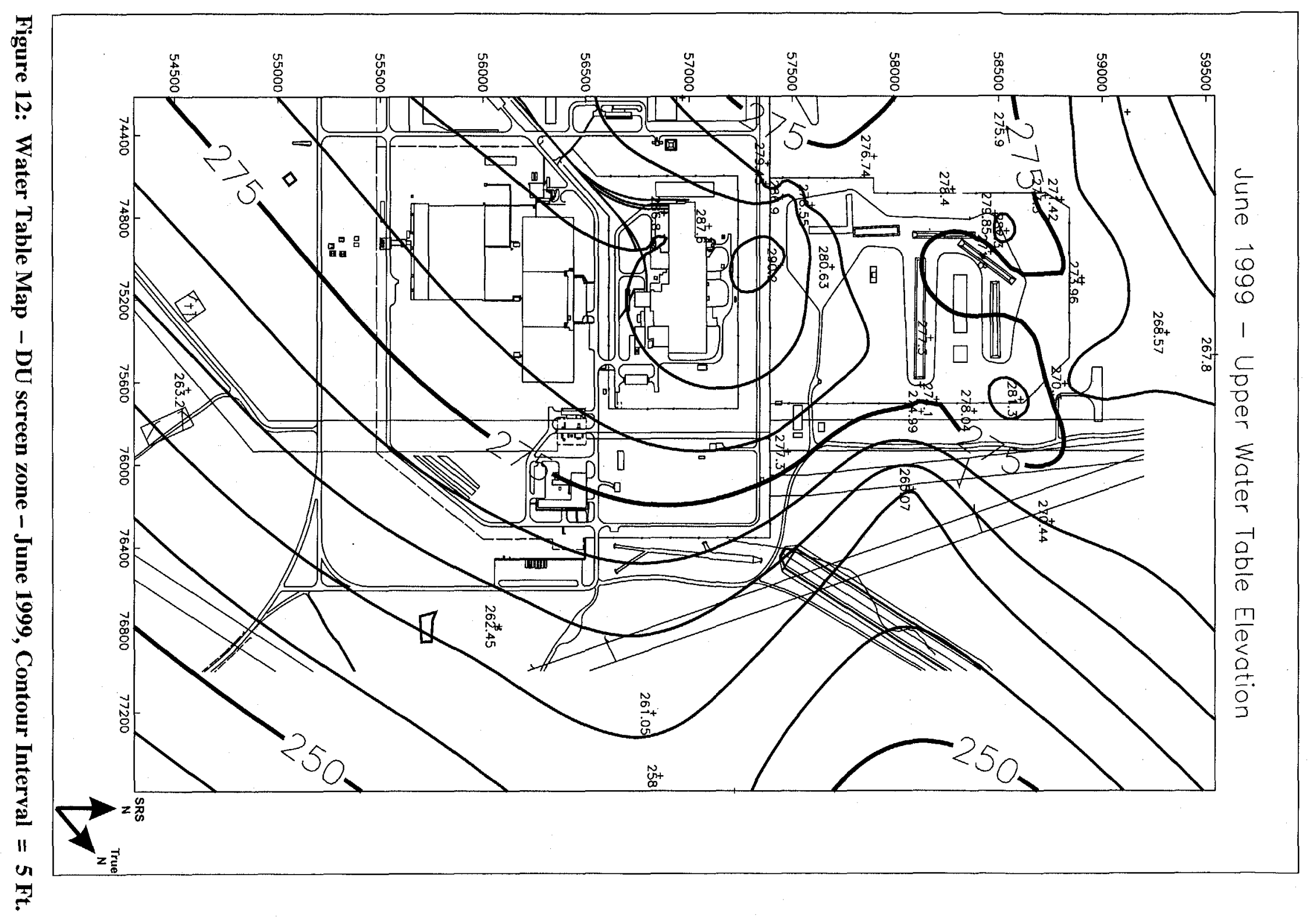




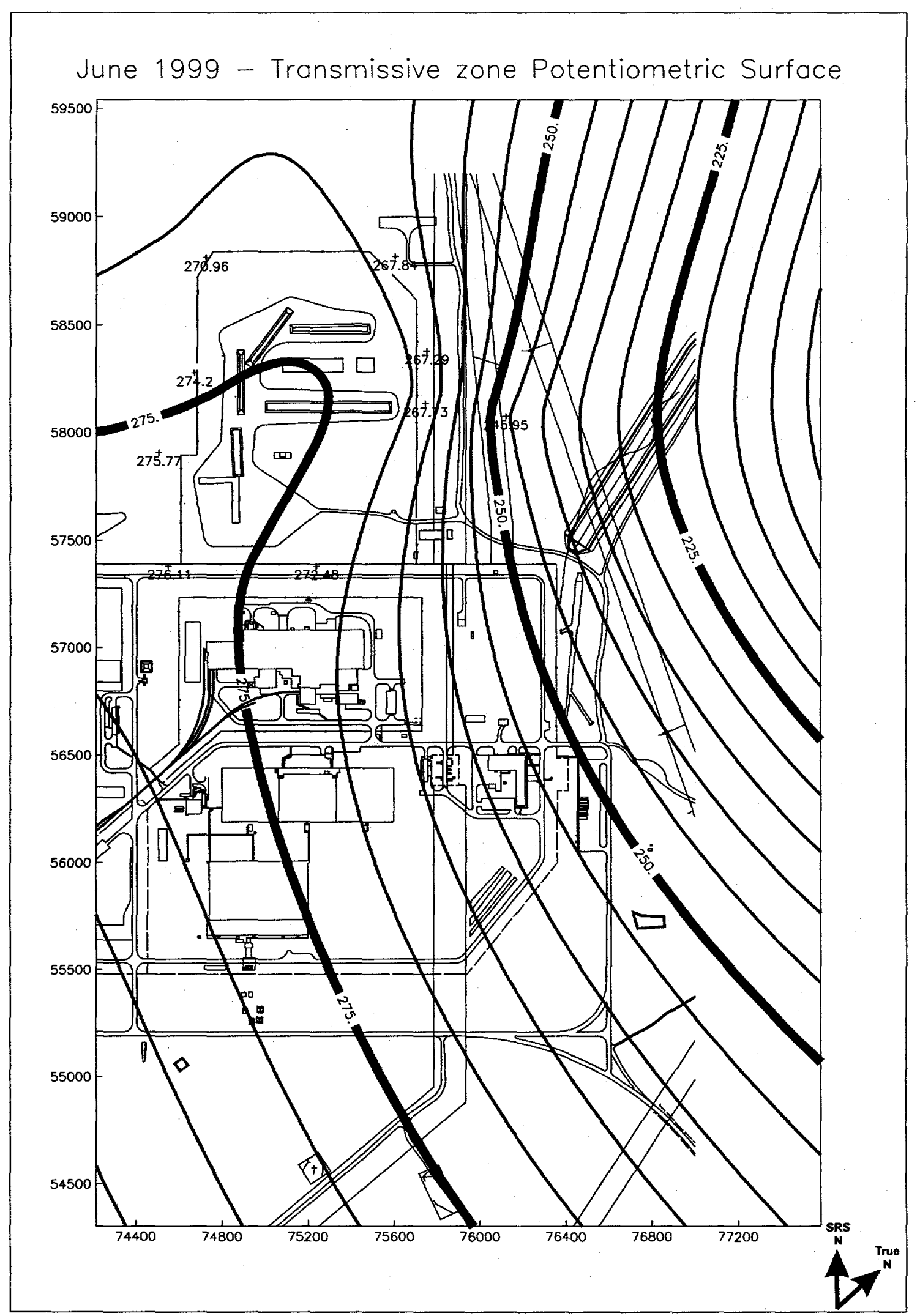

Figure 13: Transmissive zone Potentiometric Surface - DL screen zone - June 1999, Contour Interval $=5 \mathrm{Ft}$. 


\section{REFERENCES}

Argonne National Laboratory, Environmental Research Division, 1997, Evaluation Report: Study of Three Soil Moisture Probes with Laboratory Sample Results, Version 01, 8/29/97, Environmental Research Division, Argonne National Laboratory, Argonne, Illinois.

Jones, W.F., Haselow, J.S., Harris, M.K., and Denham, M.E., 1998, Groundwater Flow and Contaminant Transport for the R-Reactor Seepage Basins (U), WSRC-OS-00011, Rev. 0 HydroGeoLogic, Inc., Herndon, VA, 406 p.

WSRC, 1998, RCRA Facility Investigation Remedial Investigation Report with Baseline Risk Assessment for the R-Reactor Seepage Basins 108-4R Overflow Basin Operable Unit (U), WSRC-RP-00314, Rev. 0, August 1998, Westinghouse Savannah River Company, Aiken, SC 29808. 98

WSRC, 1999, E- Area Vadose Zone Proposed Plan, WSRC-RP-99-4039, Revision 0, 30 pages, April 1999, Westinghouse Savannah River Company, Aiken, SC 29808.

WSRC, 1999a, Additional Field Investigation R-Reactor Seepage Basins for Revised Operable Unit Strategy (U), WSRC-RP-4082, Rev. 0, June, 1999, Westinghouse Savannah River Company, Aiken, SC 29808. $\quad \hat{q} 9$

Westinghouse Savannah River Company, Current Version, WSRC 3Q5, HydroGeologic Data Collection Methods, Procedures, and Specifications. 
Appendix A - Daily Activities Report 
This page intentionally left blank
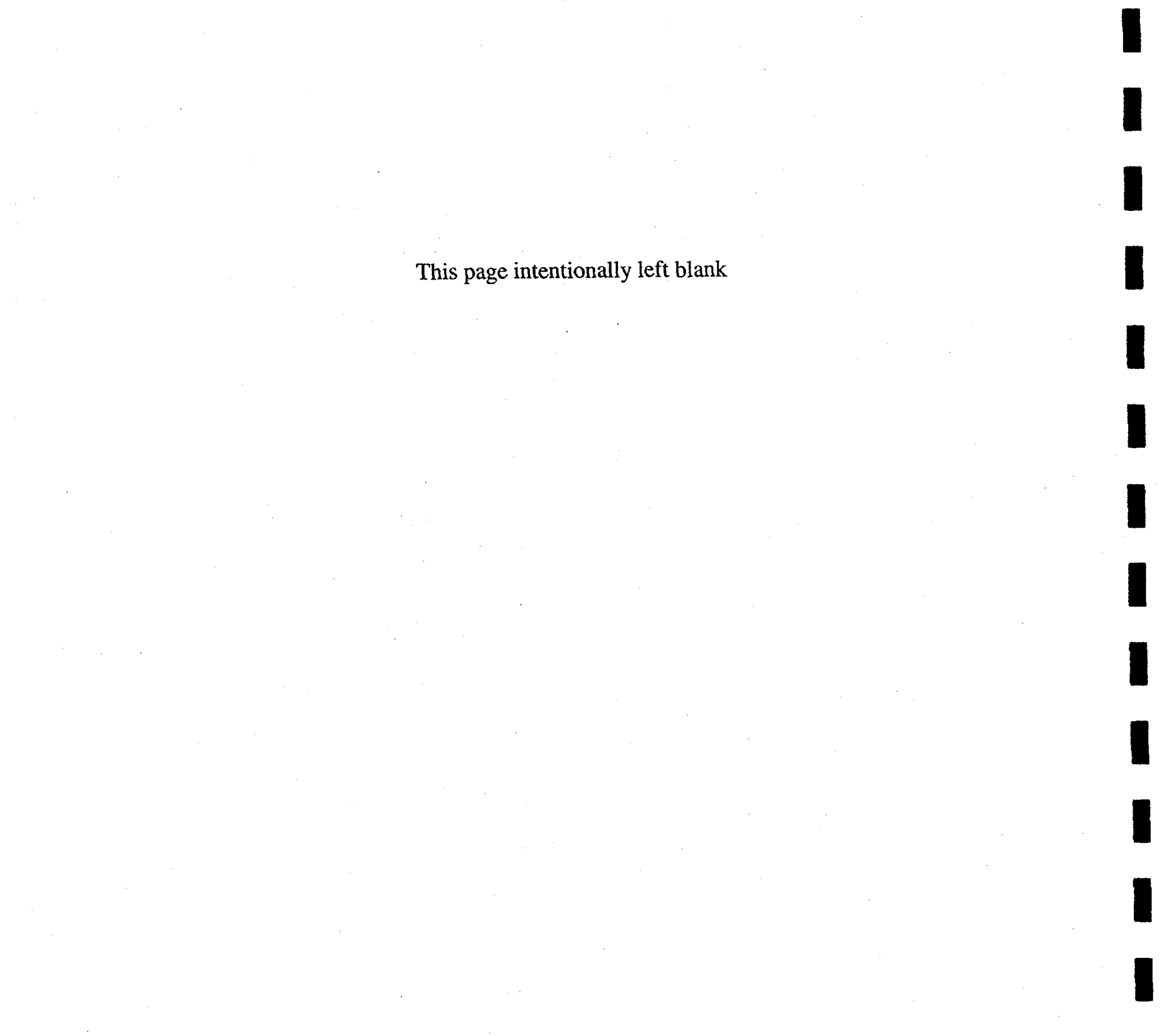


\section{Daily Activities Report}

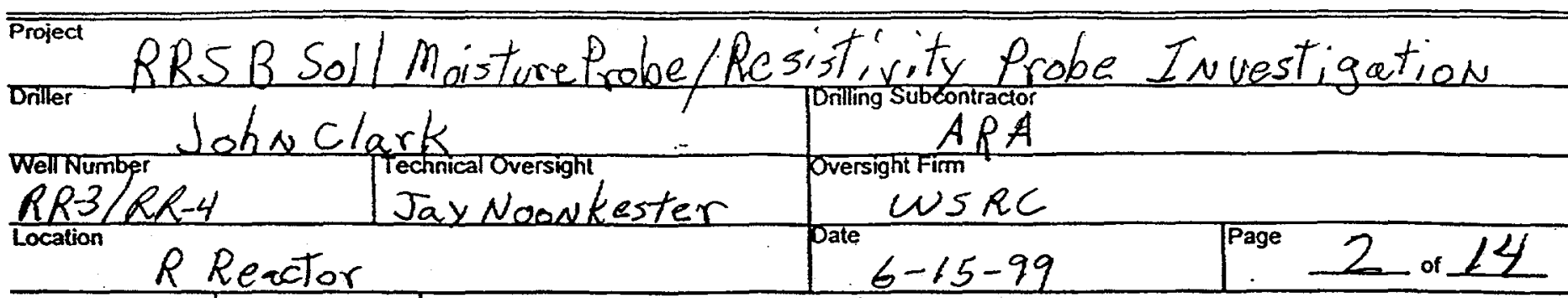

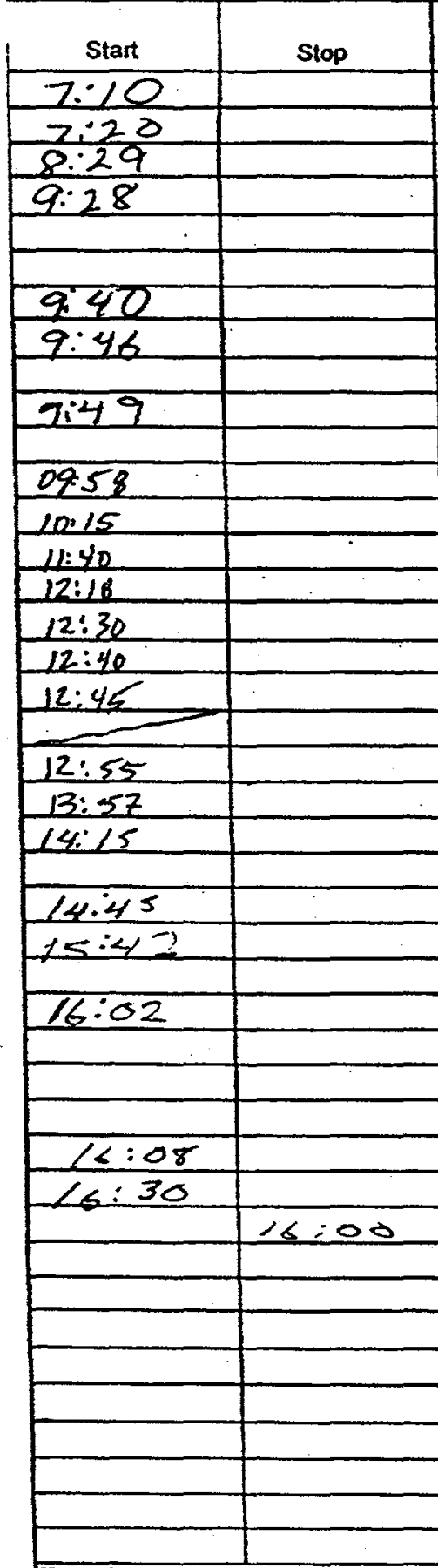

Oreasizht on location, $R R-3$

Crew setip baracade and bave been aclibiating

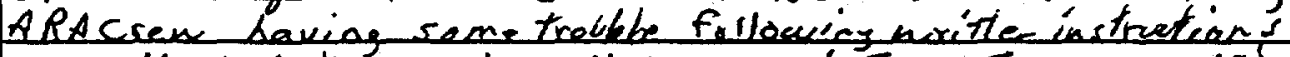
To Cali: noistwe prober blad to cull to getmare specific herections $R R-3$ push.

Joel left tagoto Brocetrimletis affice expects To de gane is hre lob is shut down wat'l he rectures.

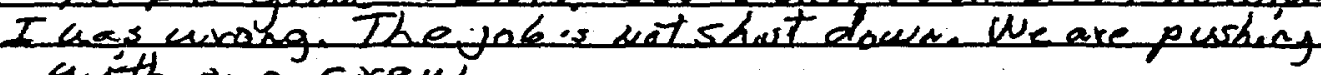
a th owe crew.

W. Jomes ansite to rephace J. Noonkertertompexscily wI briefed by $I N$,

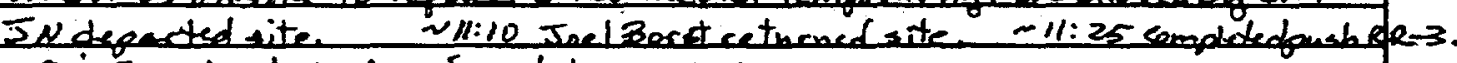

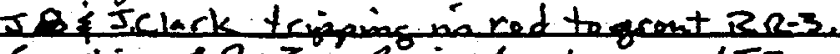

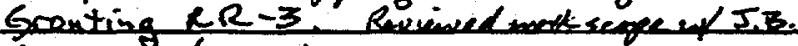

Completed aventing RR-3.

Mebilining fo $R R-4$ ?

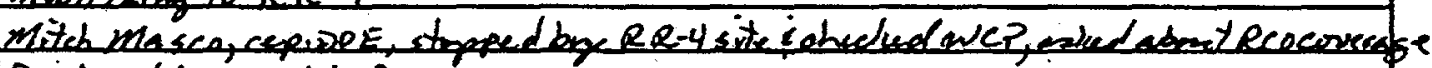
for locetions splin fence.

mindeponded site.

J.N. Returened siti.

complete RR-4, Preparing to grout.f.osT Tlepingen rods.

rods Triped oct.

loel has been Trying Toprint out hogs. He is on tha phear

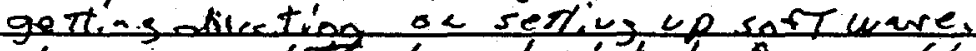

logs aie pletted and printed. One problem: The software on Truckis off rersian and does nit ieconize so.' moisture.

bleel will rea tate on his conpeter tonight and shacld be able. To erint it in the morring.

ANA crew is now calibrating-

Colibraton conclete.

Finished for Todse.

Technical Oversight Signature

fa, Nonkets

Date $6-15-99$ 


\section{Daily Activities Report}

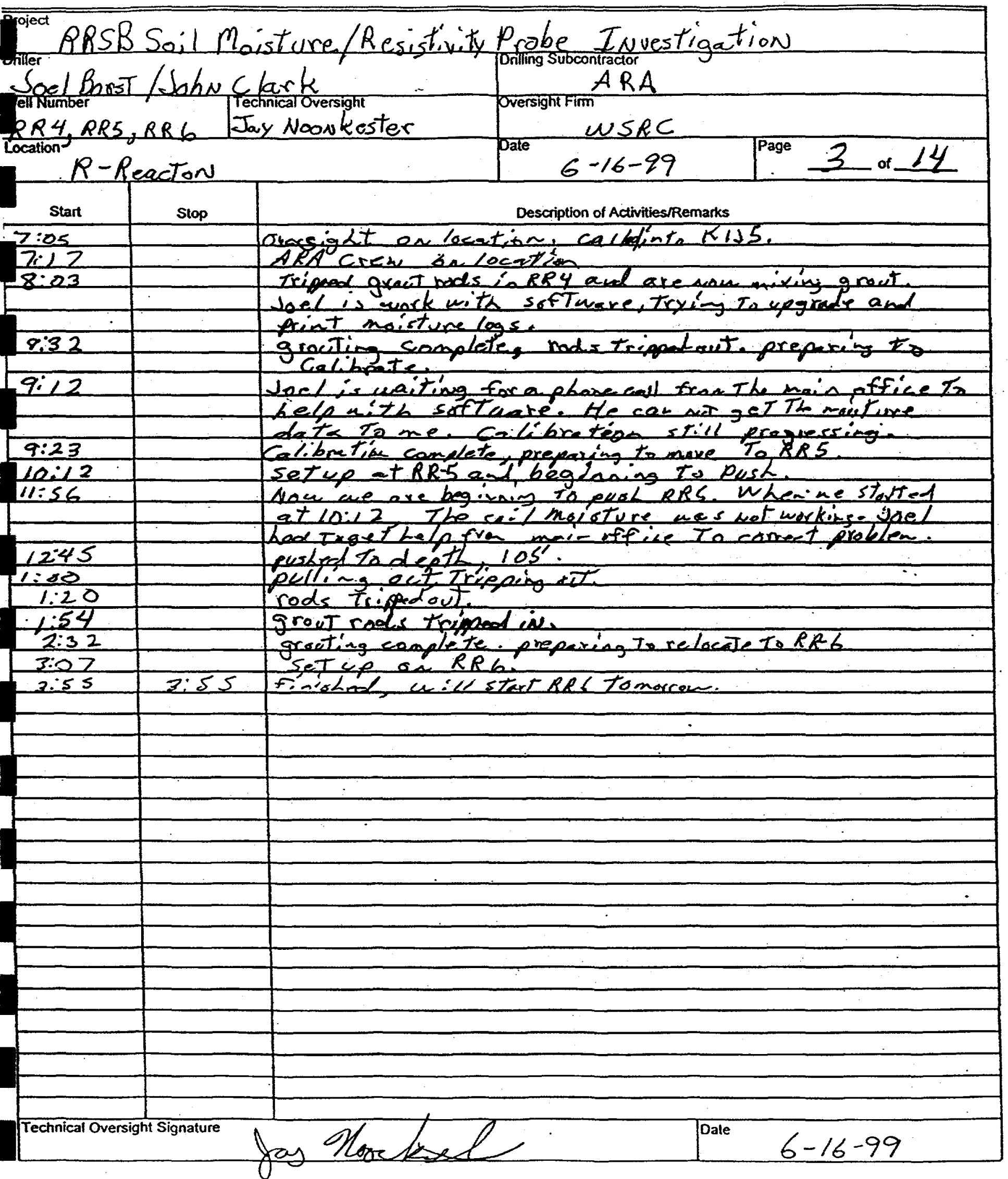




\section{Daily Activities Report}

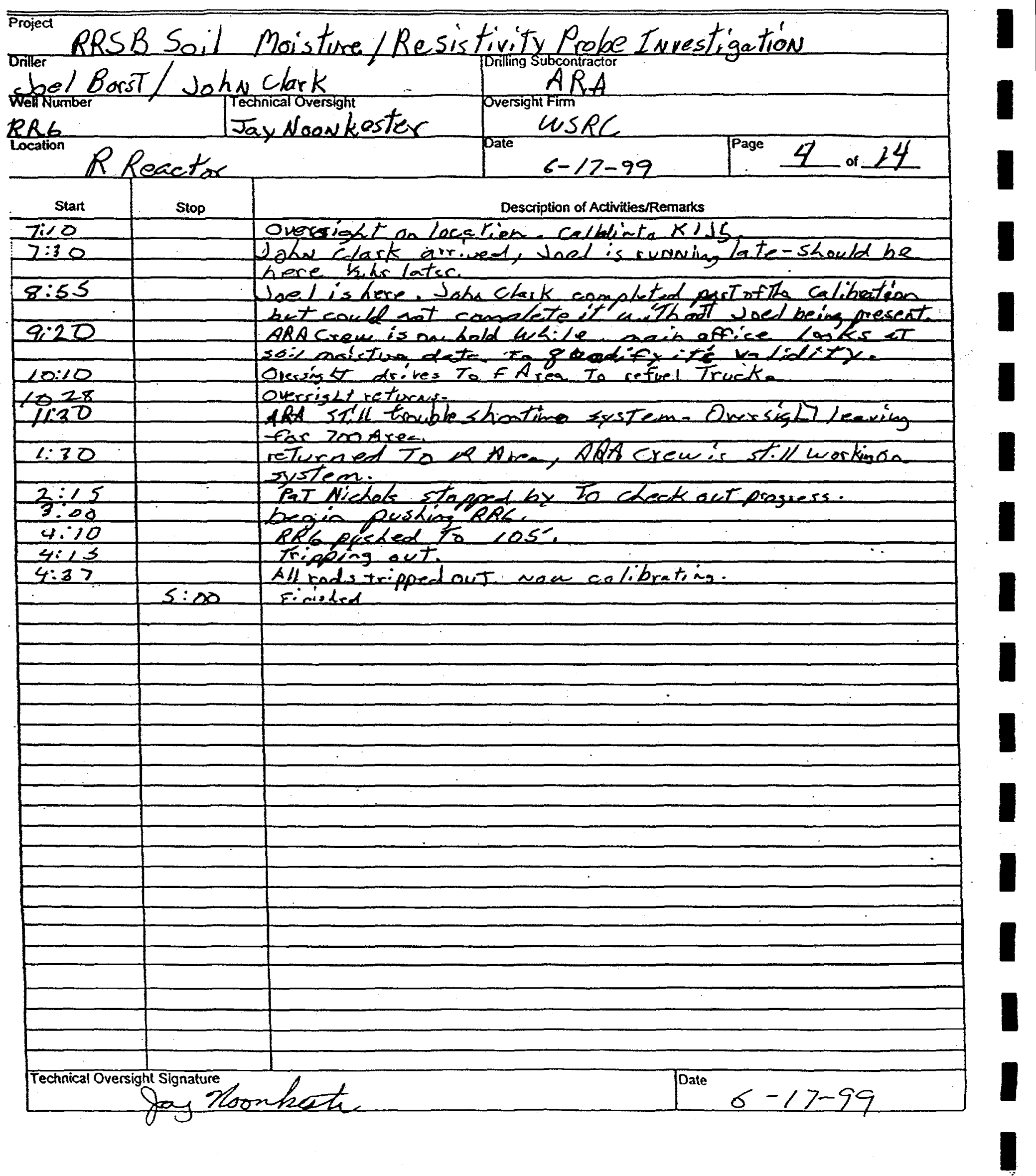




\section{Daily Activities Report}

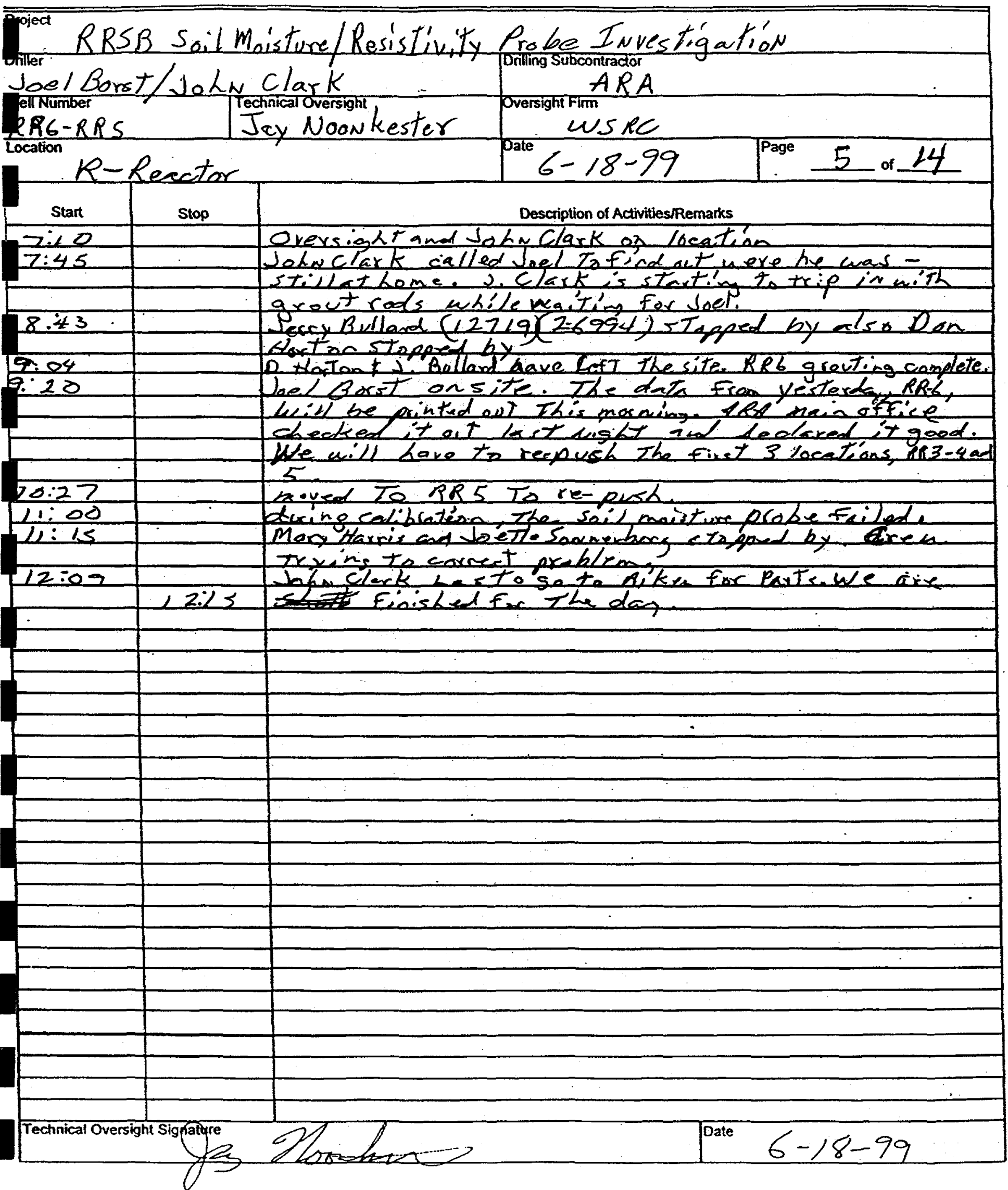




\section{Daily Activities Report}

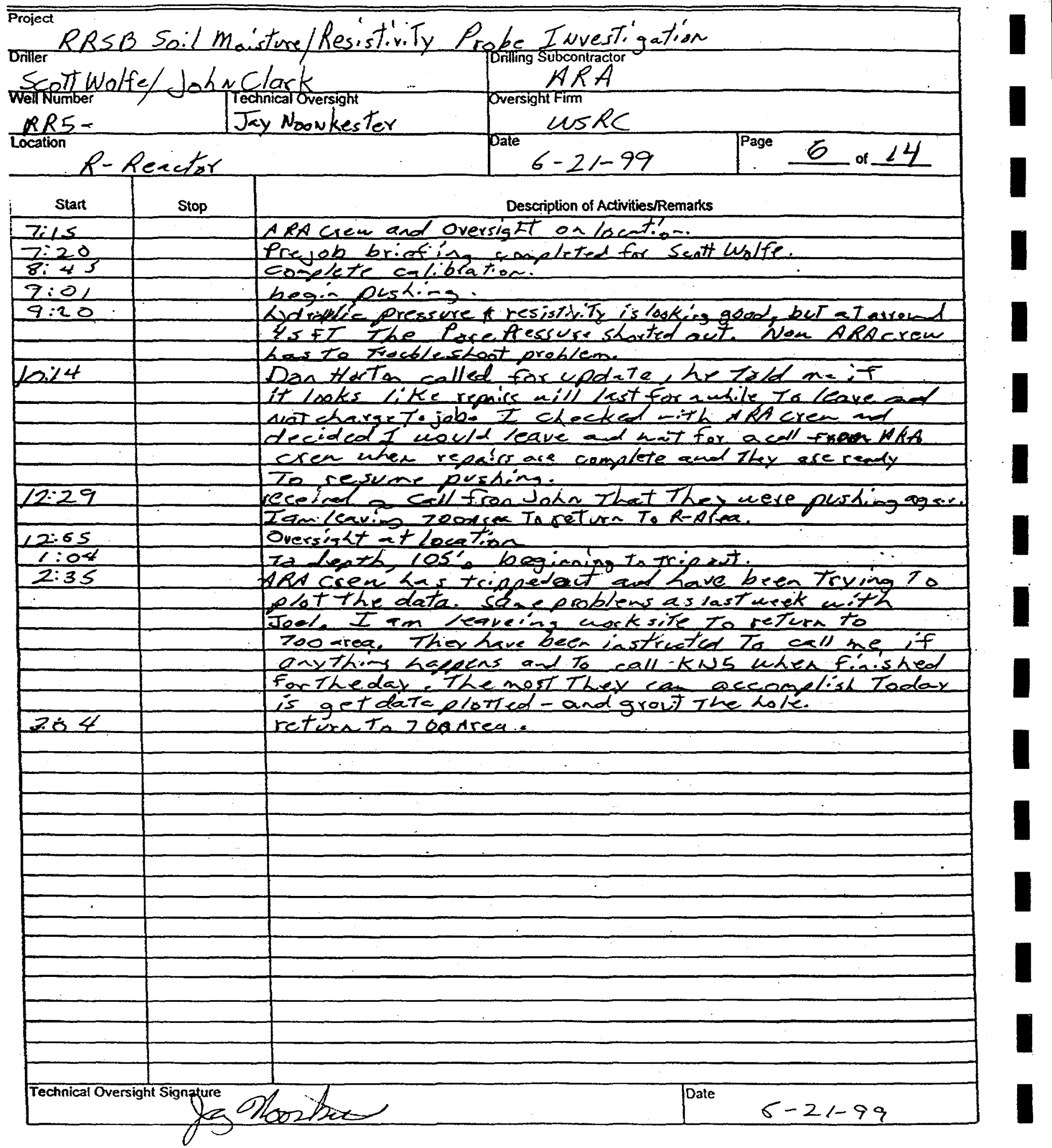




\section{Daily Activities Report}

oject

Dritler

RRSB Soil Moisture/Resist'. ViTy Investigation

Scottwolfe/ Johw clark

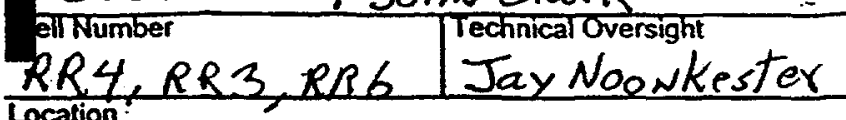

Location

RReator

briling subcontracio

oversight firm
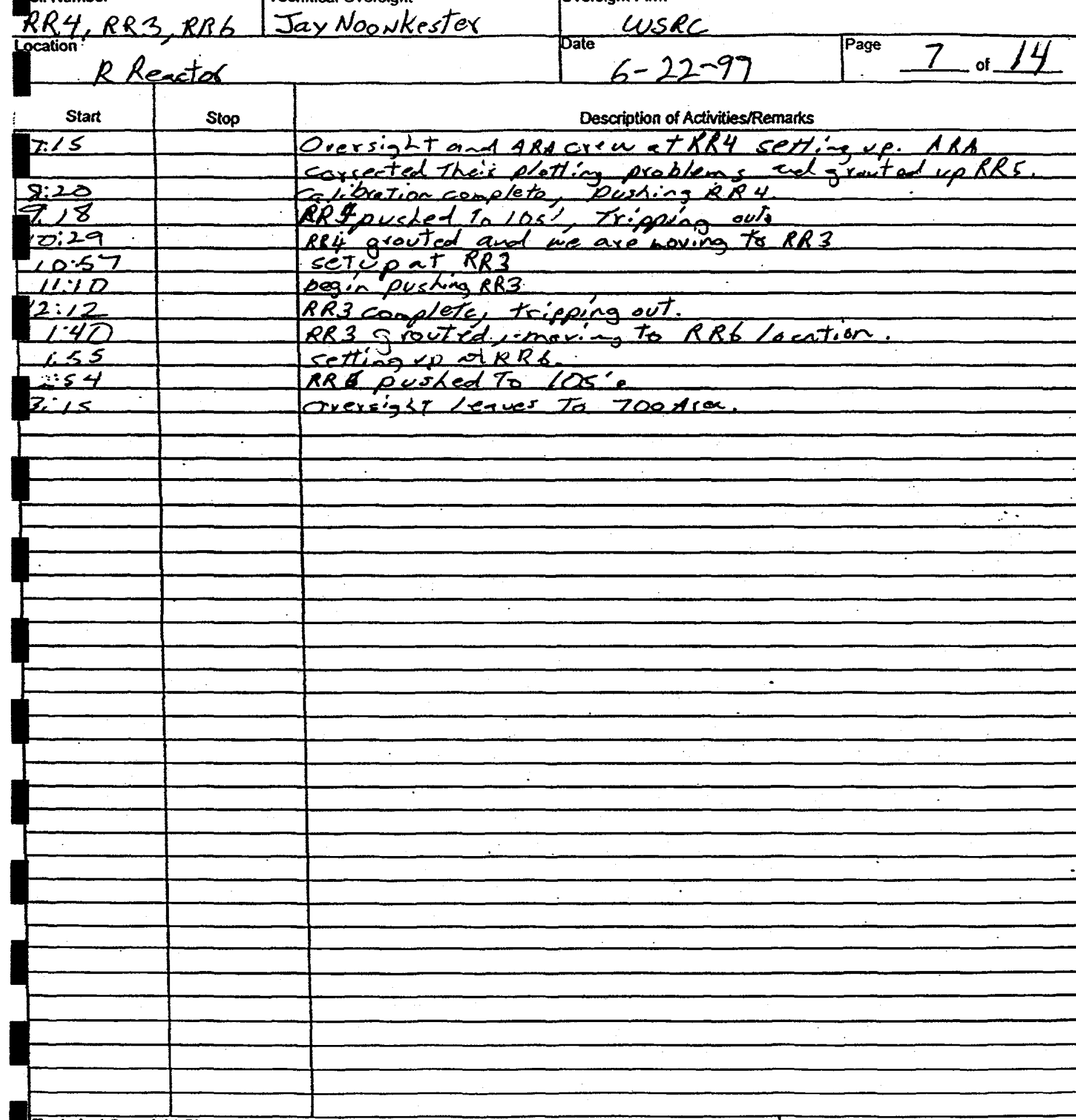

Technical Oversight Signature

Og aromter

Description of Activities/Remarks

Orersight and 4 Rd cren a $R R_{4}$ setting wp. ARA corrected their eletting problems end greutal up $R R 5$. celibretion comelete, pushing ks 4

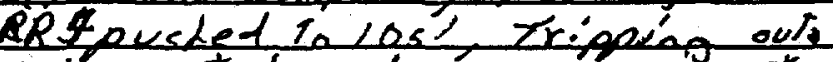

$R{ }_{4}$ grouted and we are woving to $R R 3$

setepat RR3

egein pushing $R R 3$.

RR3 cooplete tripping out.

RR3 grouted i-maring to RR6 location.

cettiog ep ot KR6

RRE pusked To lOS'e

oreveigst leques to zoedrax. 


\section{Daily Activities Report}

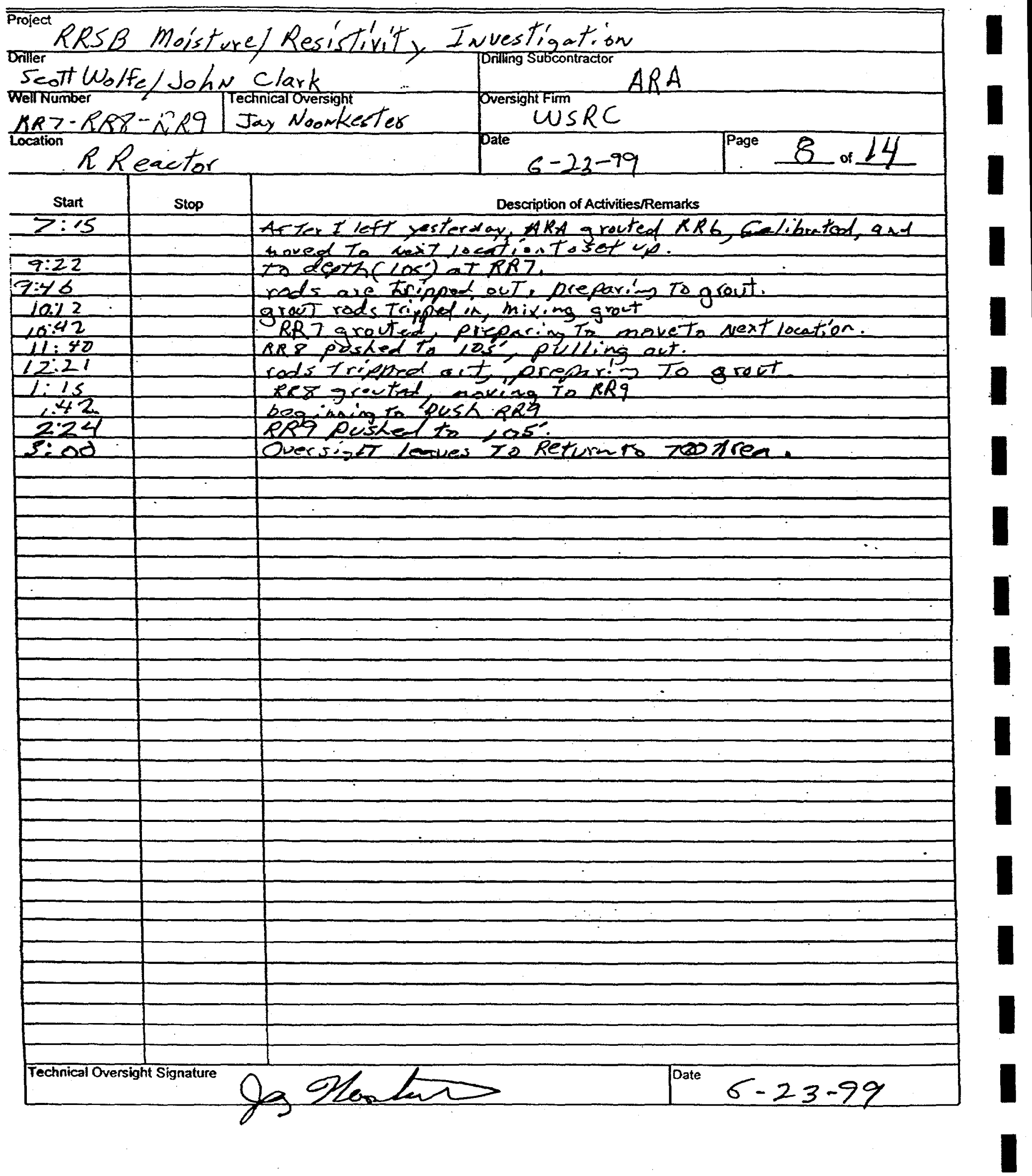


SRL-TR-9S-00330

30.28* (2-13-9?)

\section{Daily Activities Report}

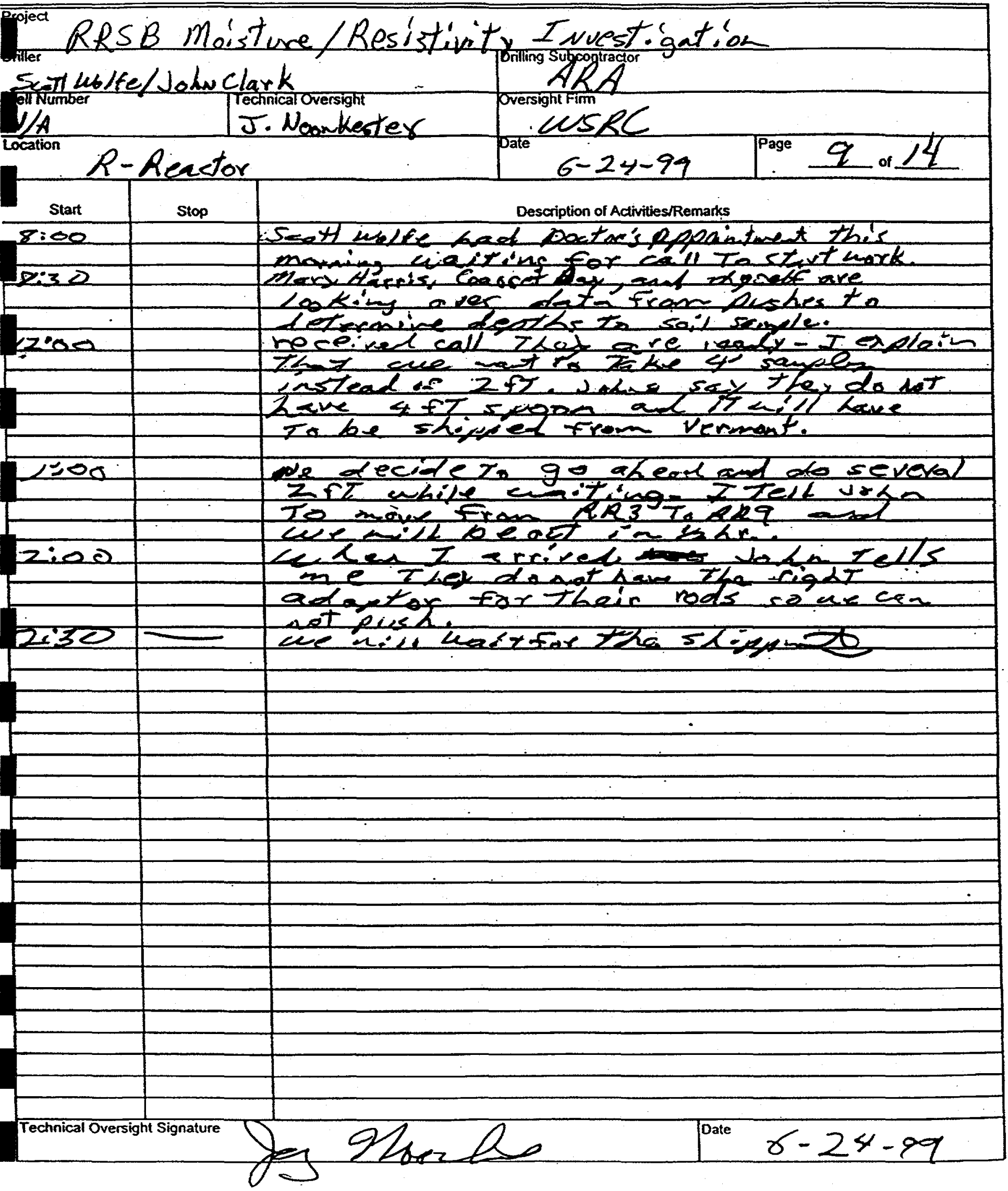




\section{Daily Activities Report}

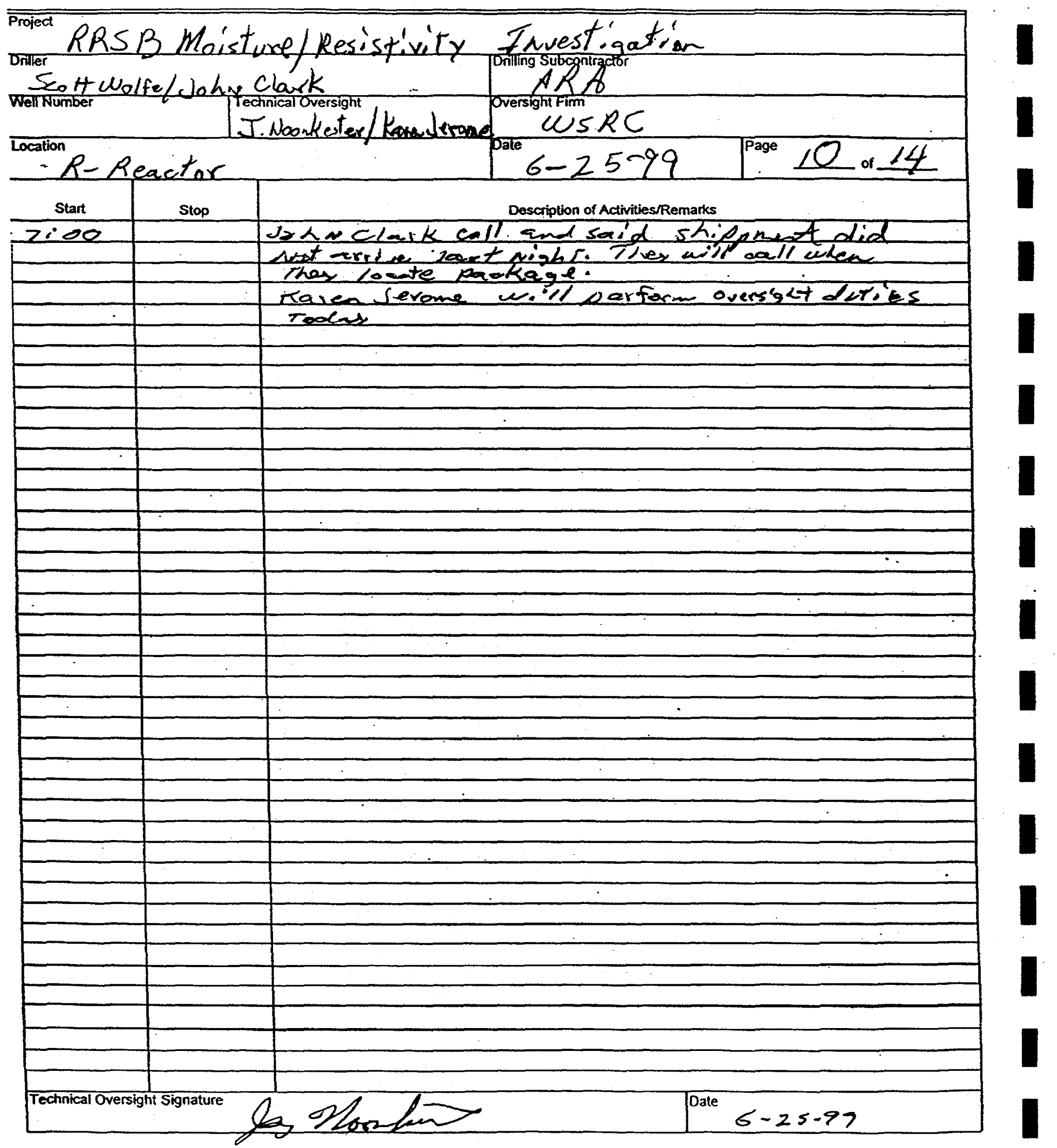


SRC-TR-S9-00330

\section{Daily Activities Report}

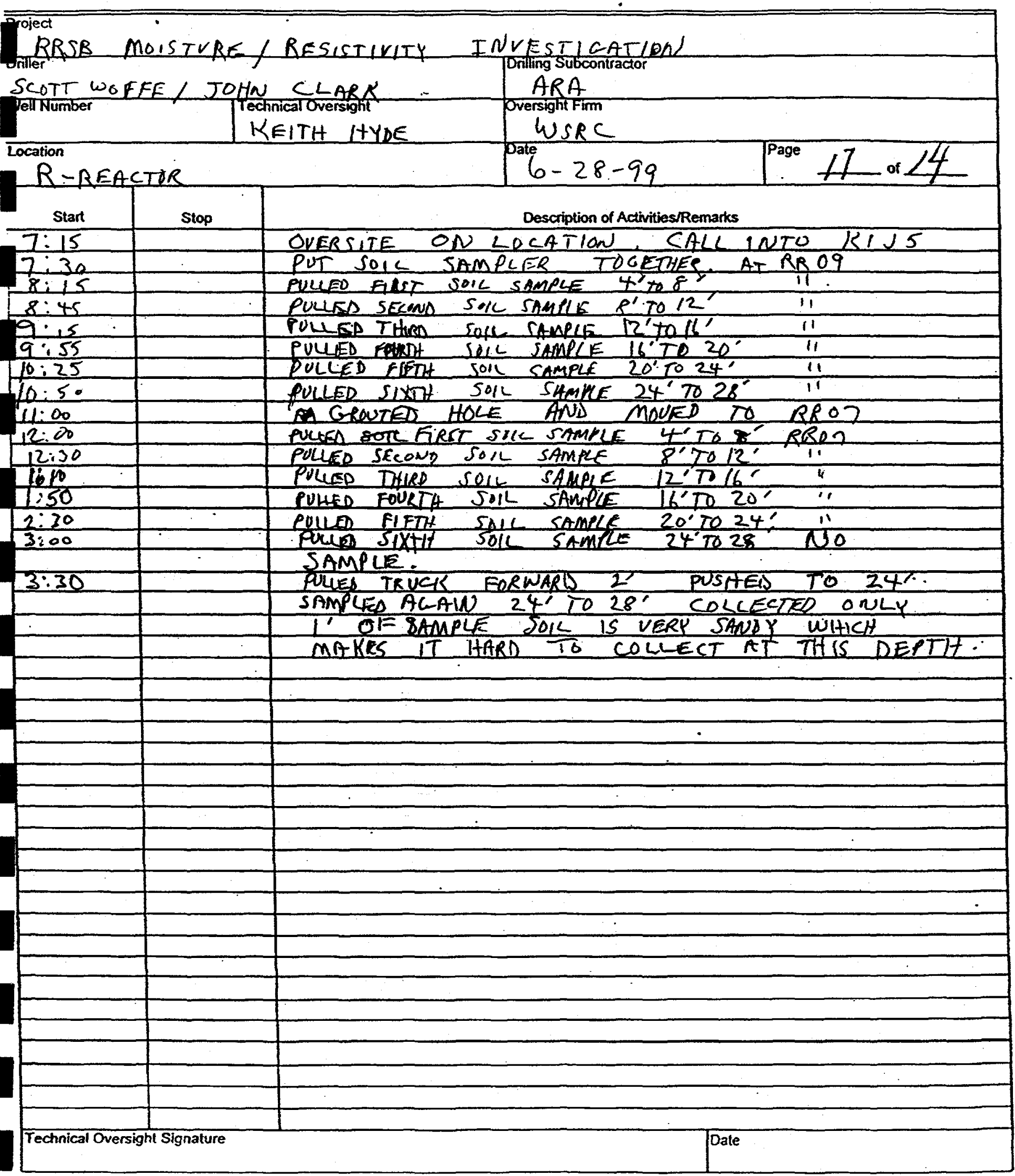




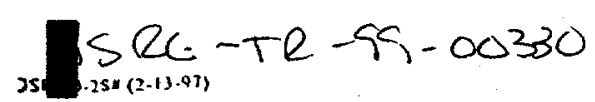

\section{Daily Activities Report}

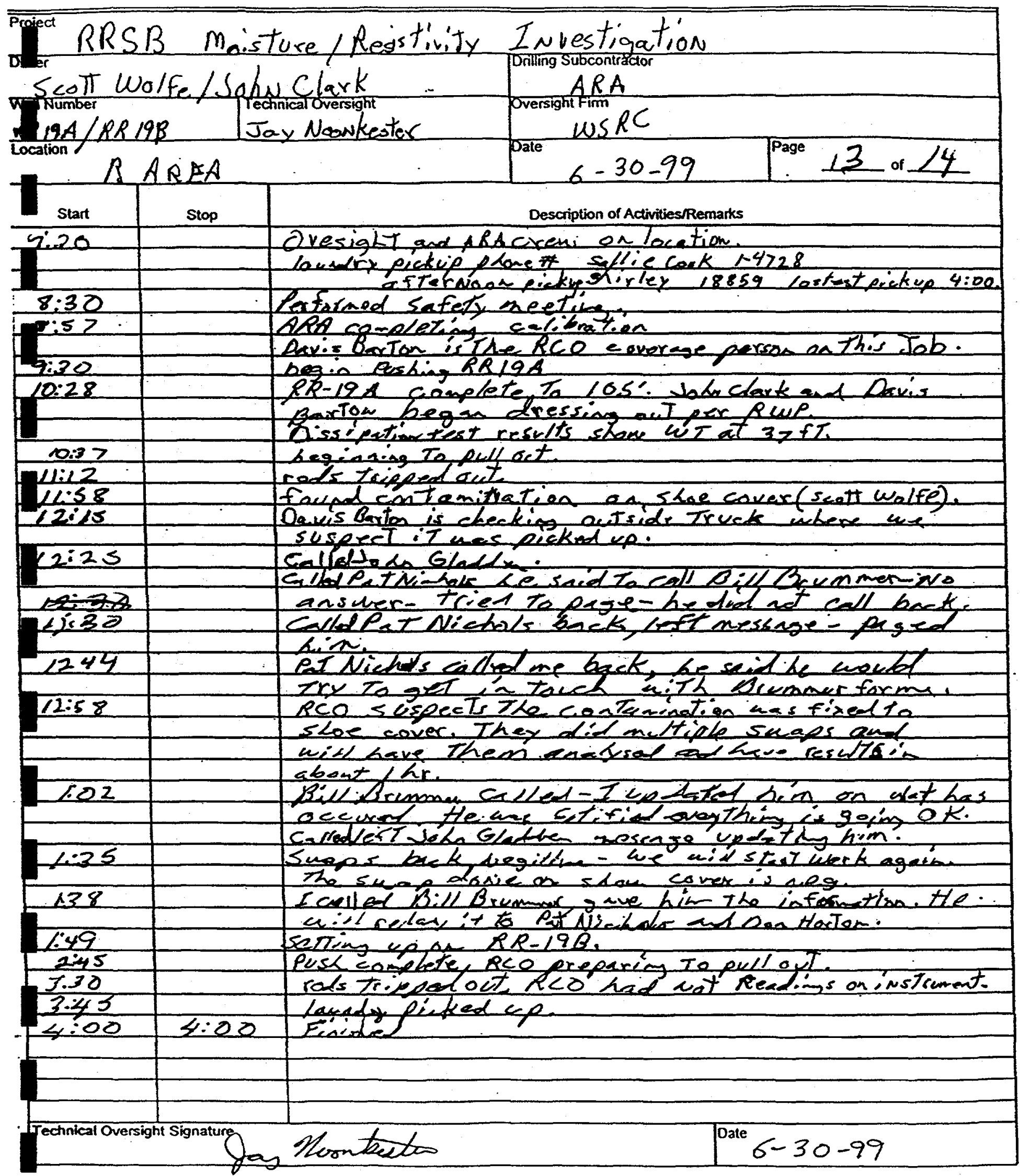




\section{Daily Activities Report}

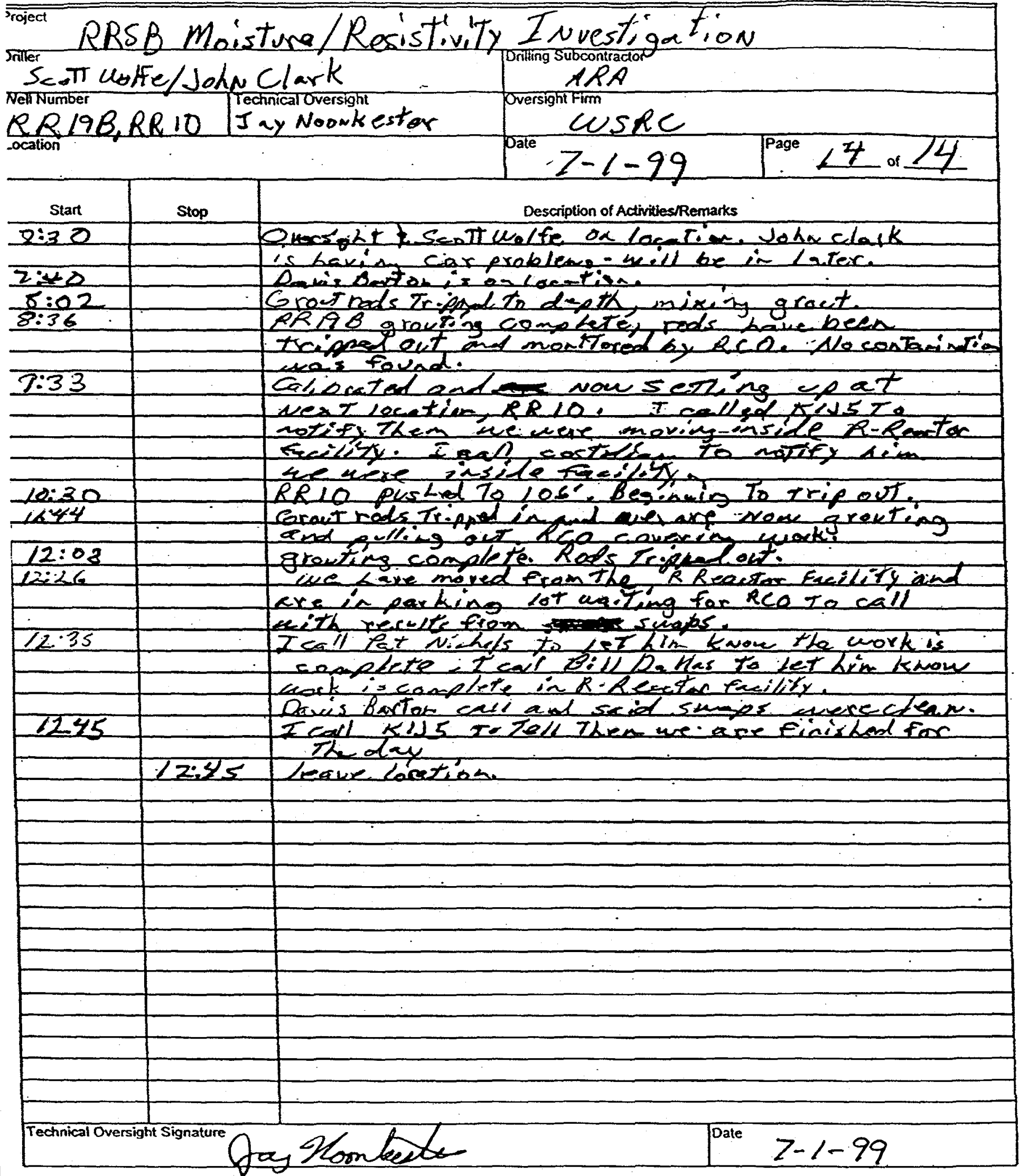


Appendix B - Cone Penetrometer Data 


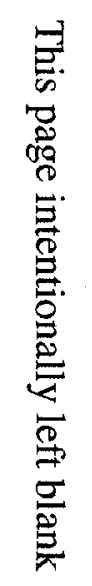




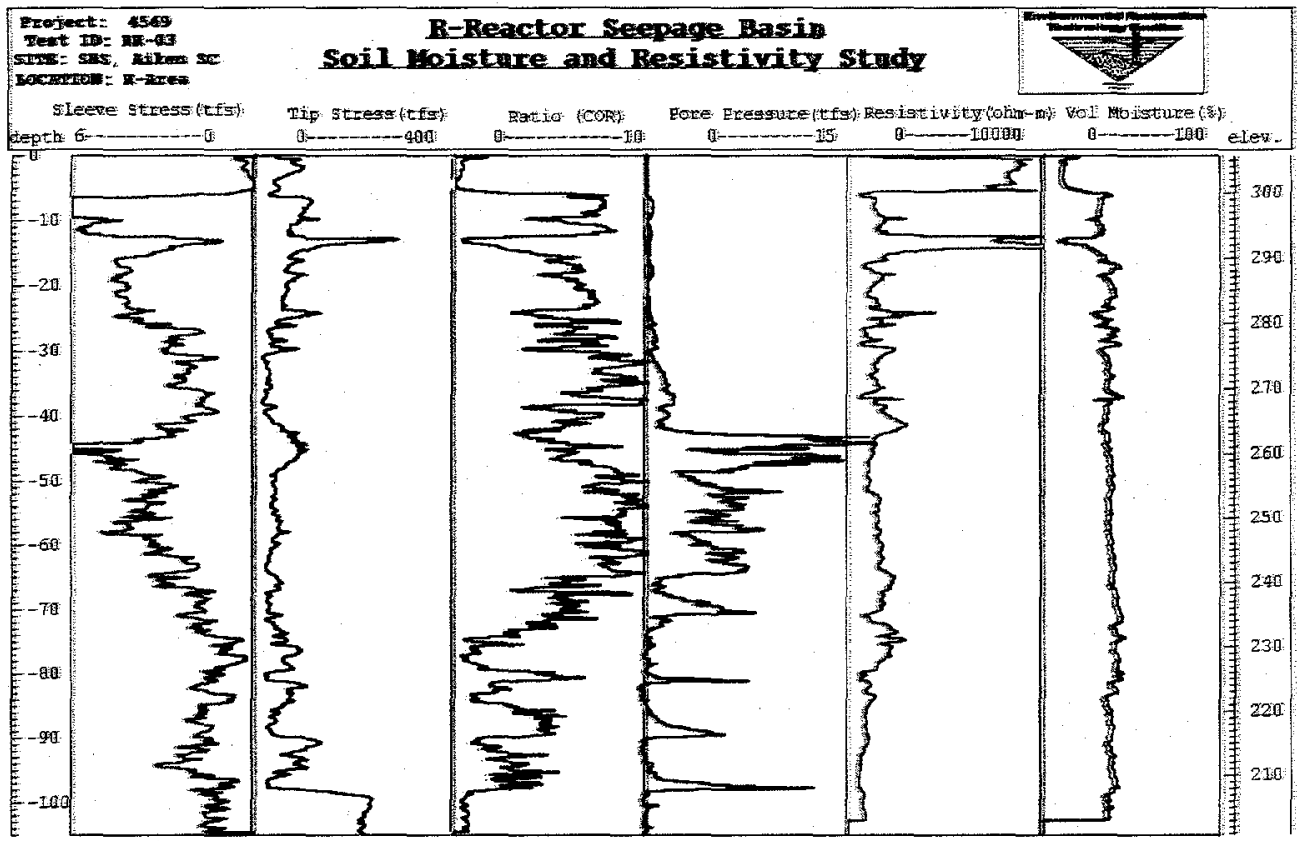

RR-03

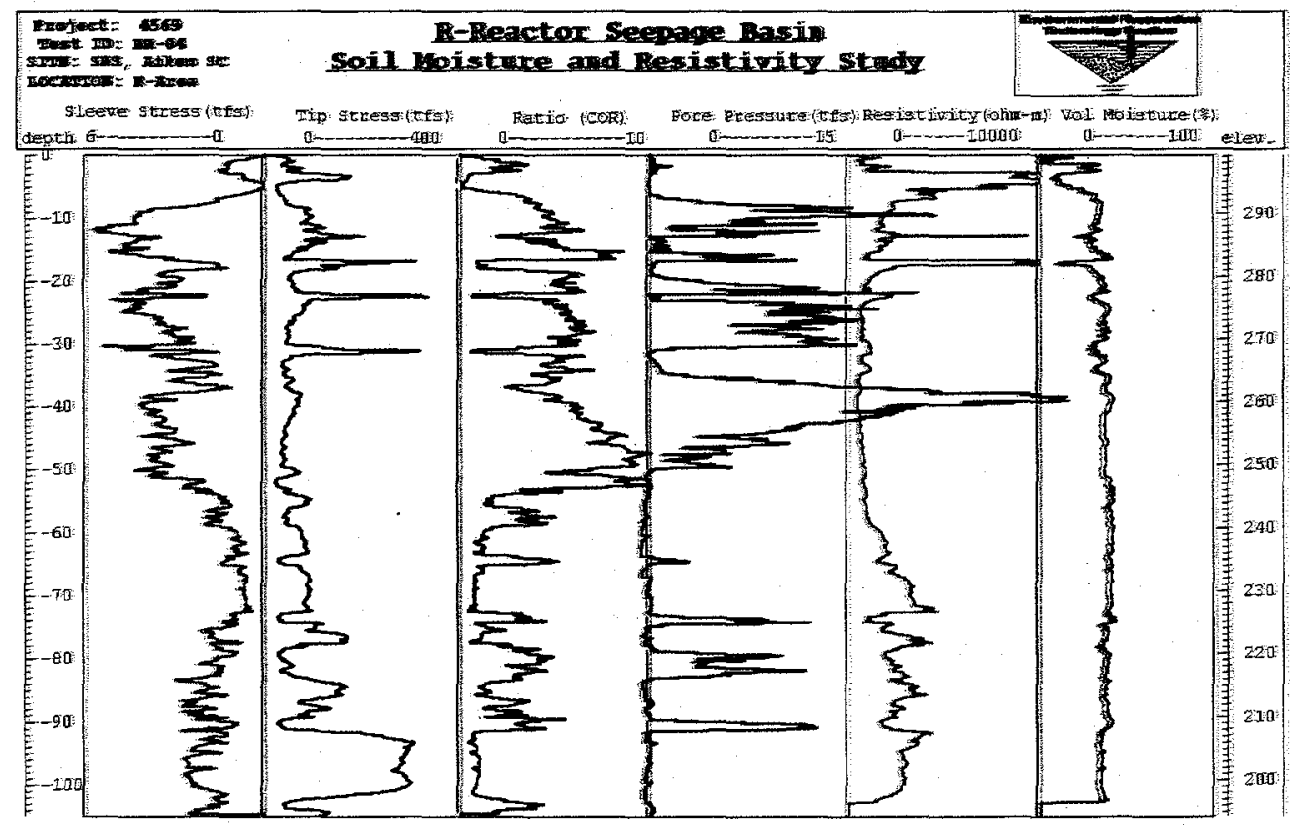




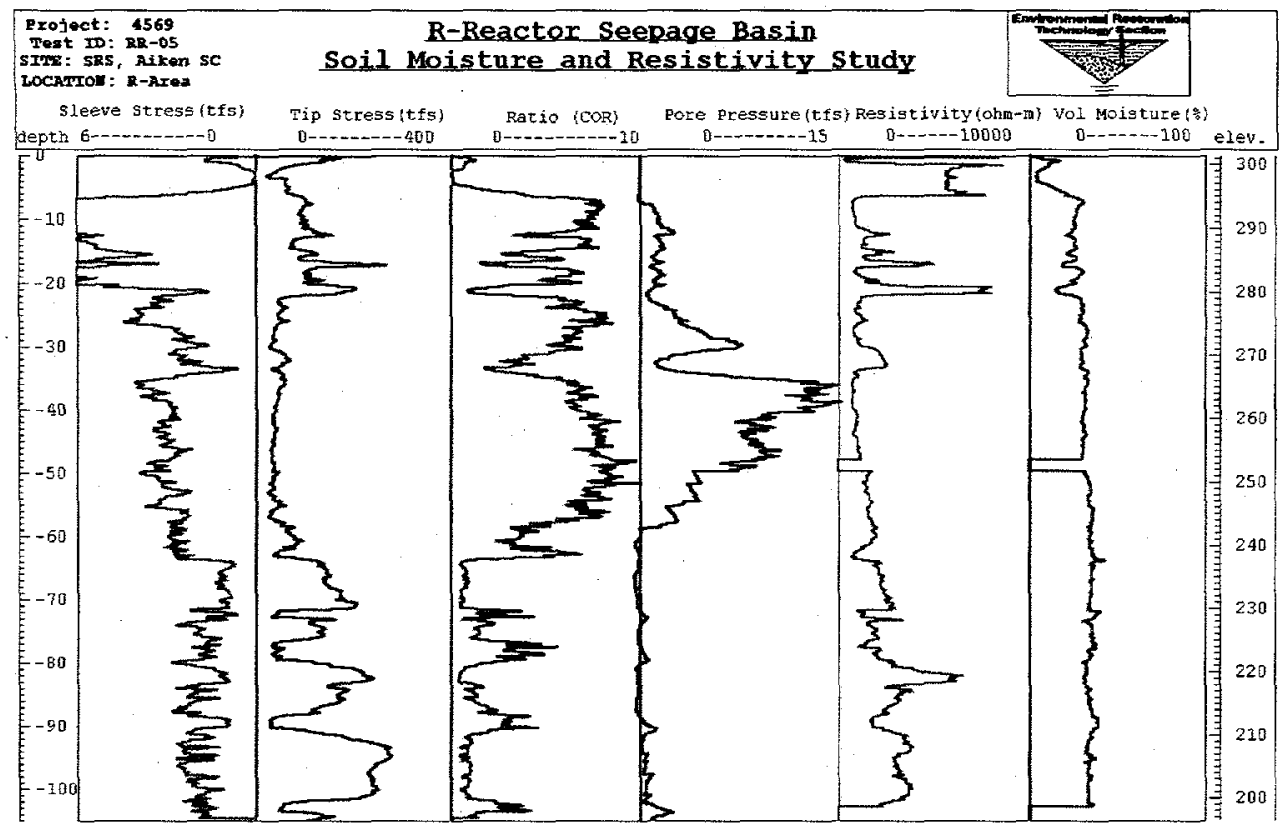

RR-05

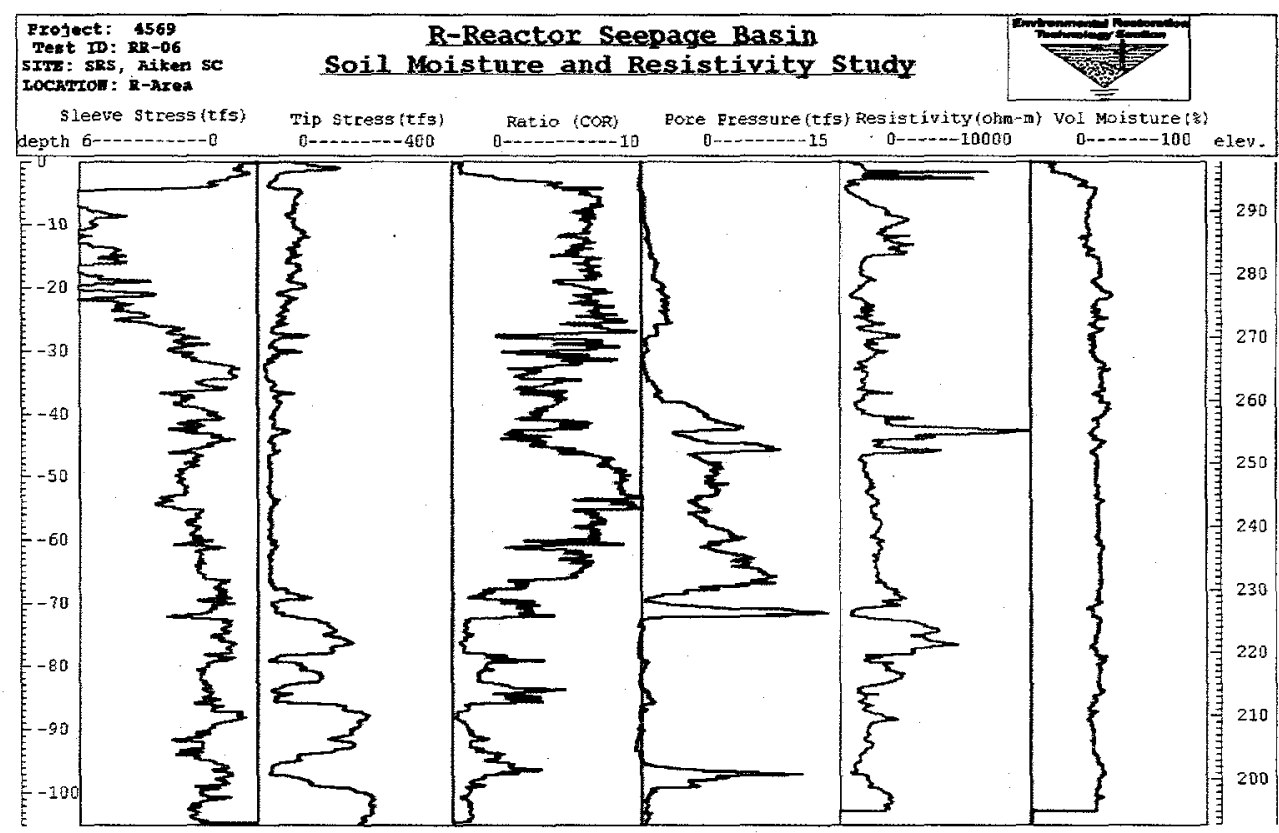

RR-06 


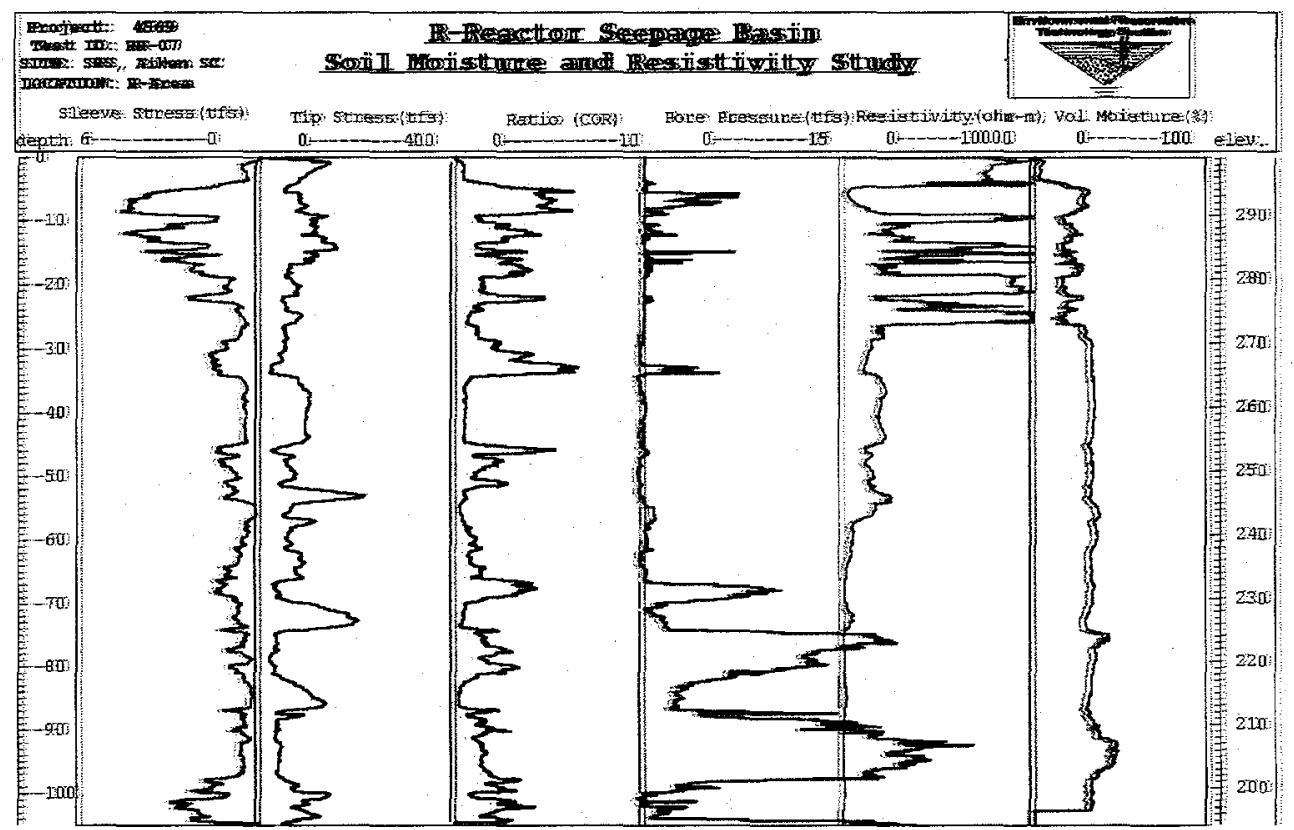

RR-07

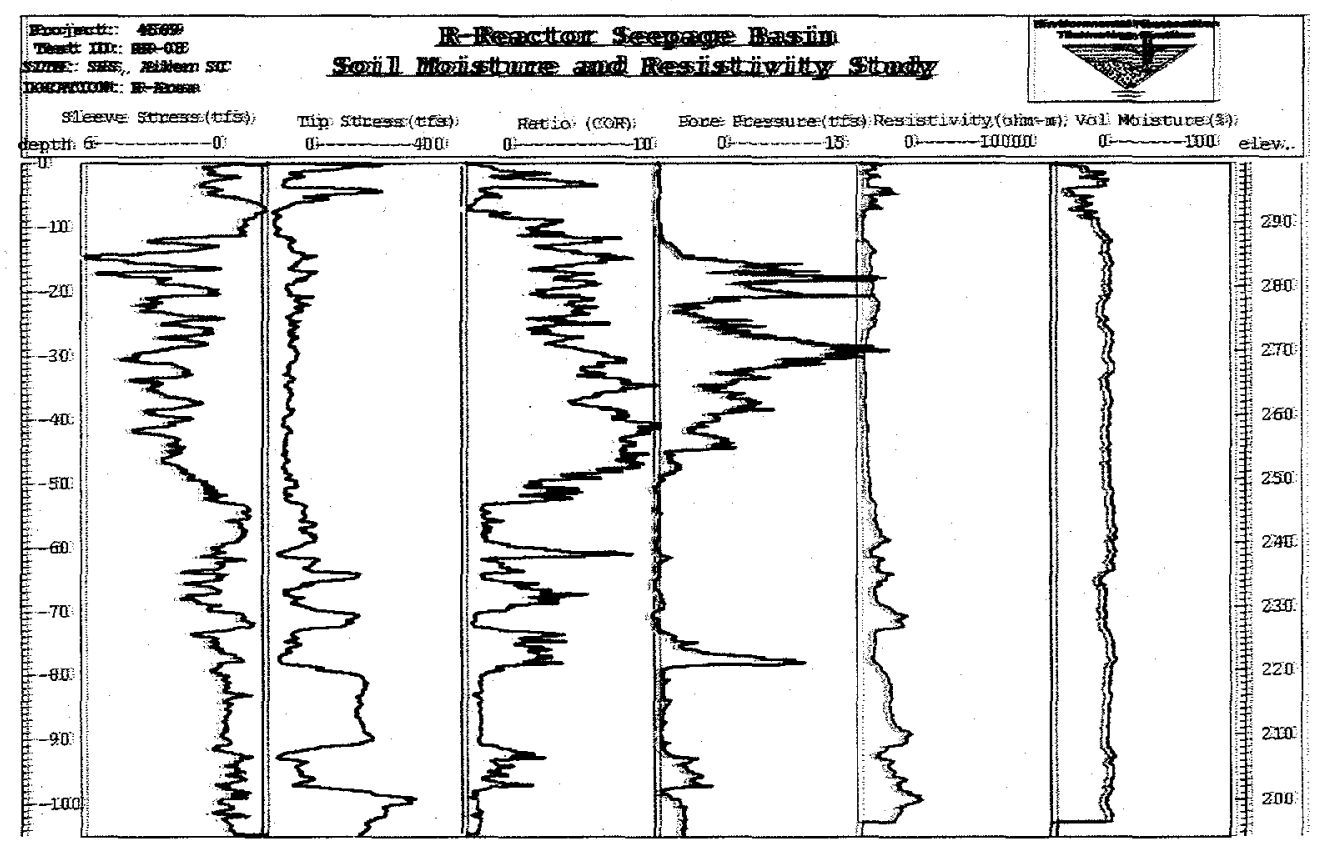




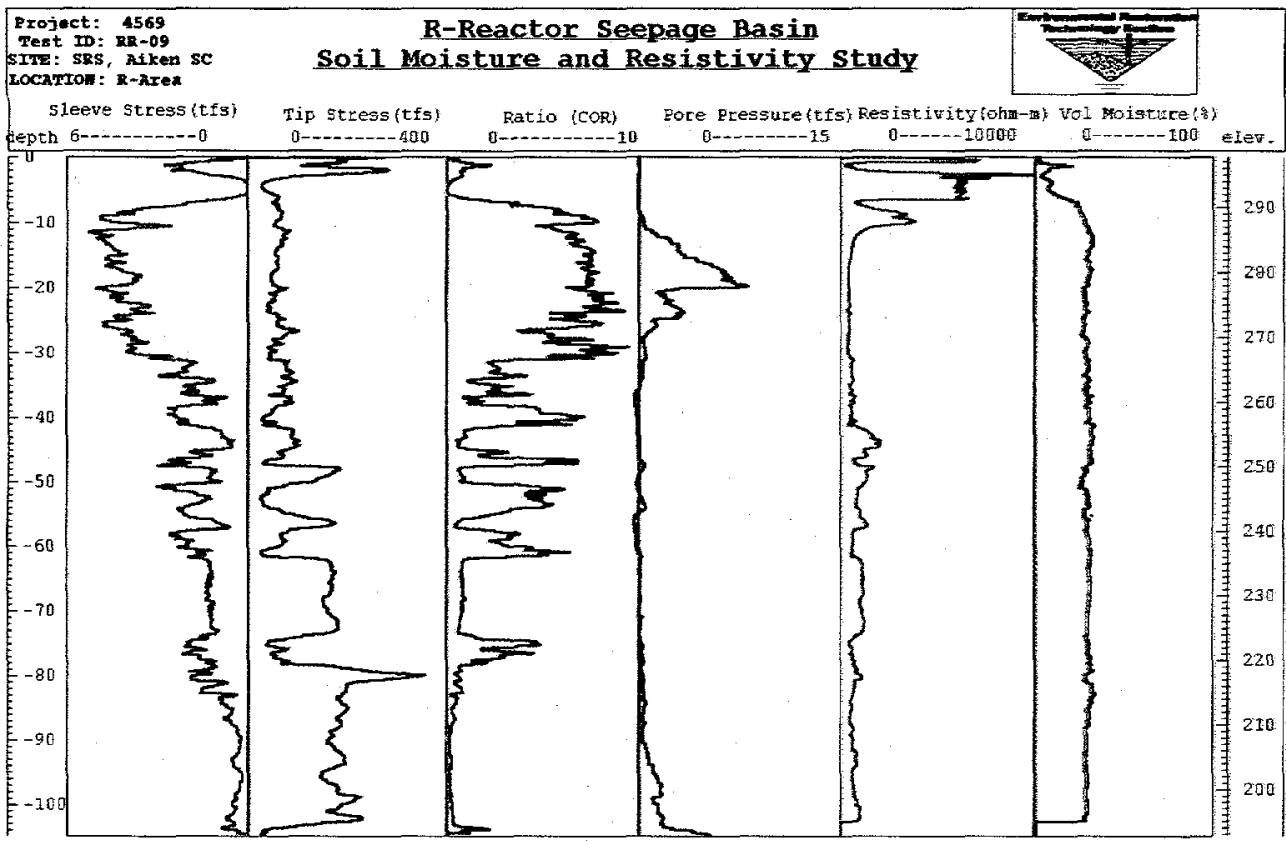

RR-09

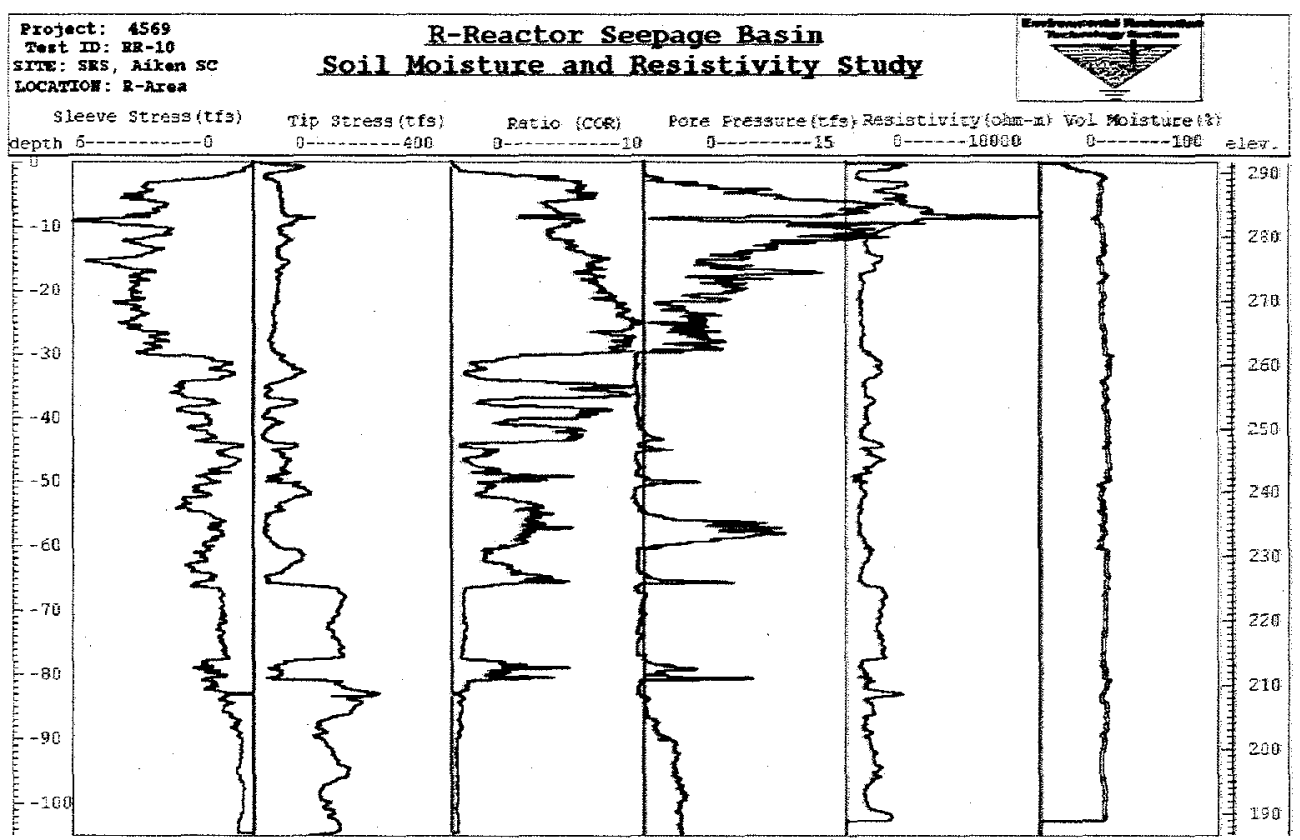




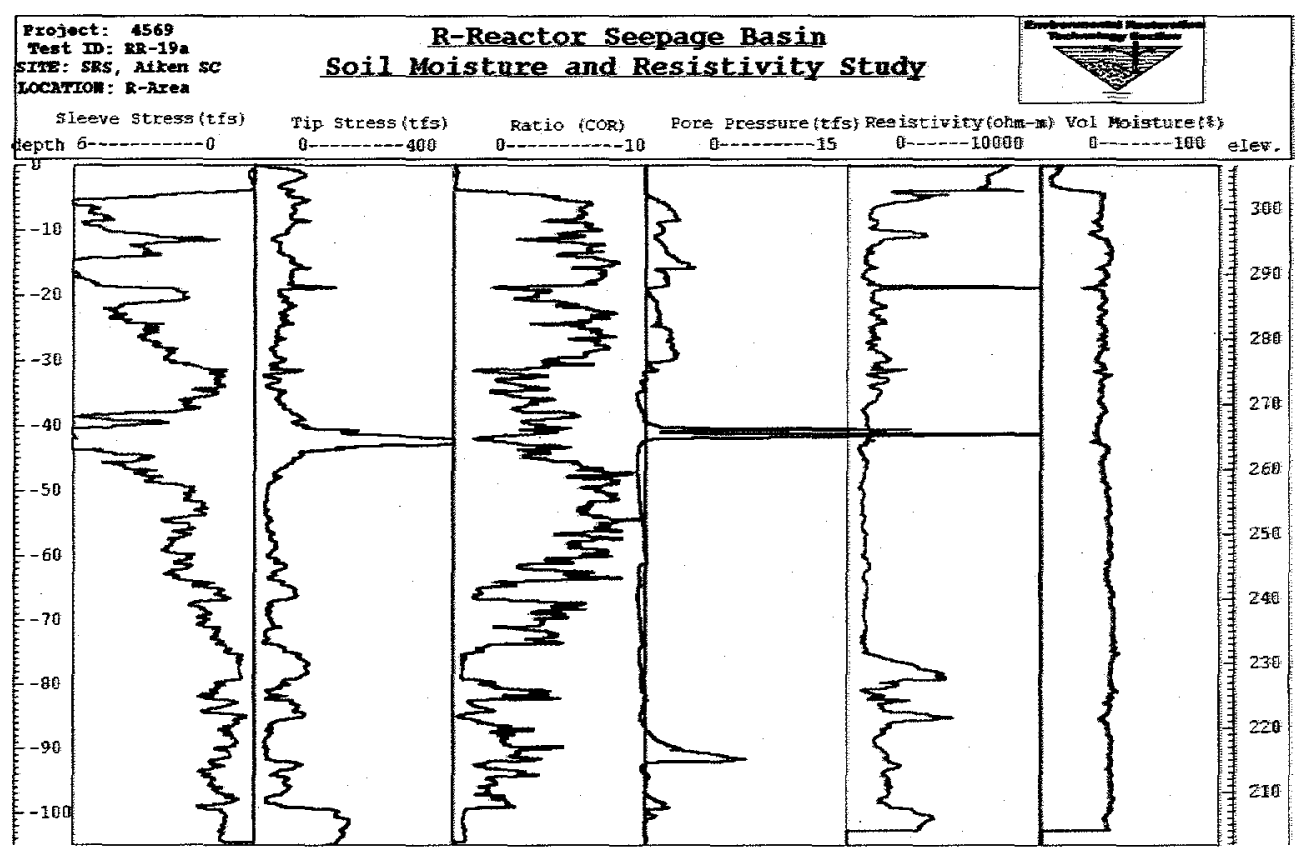

RR-19A

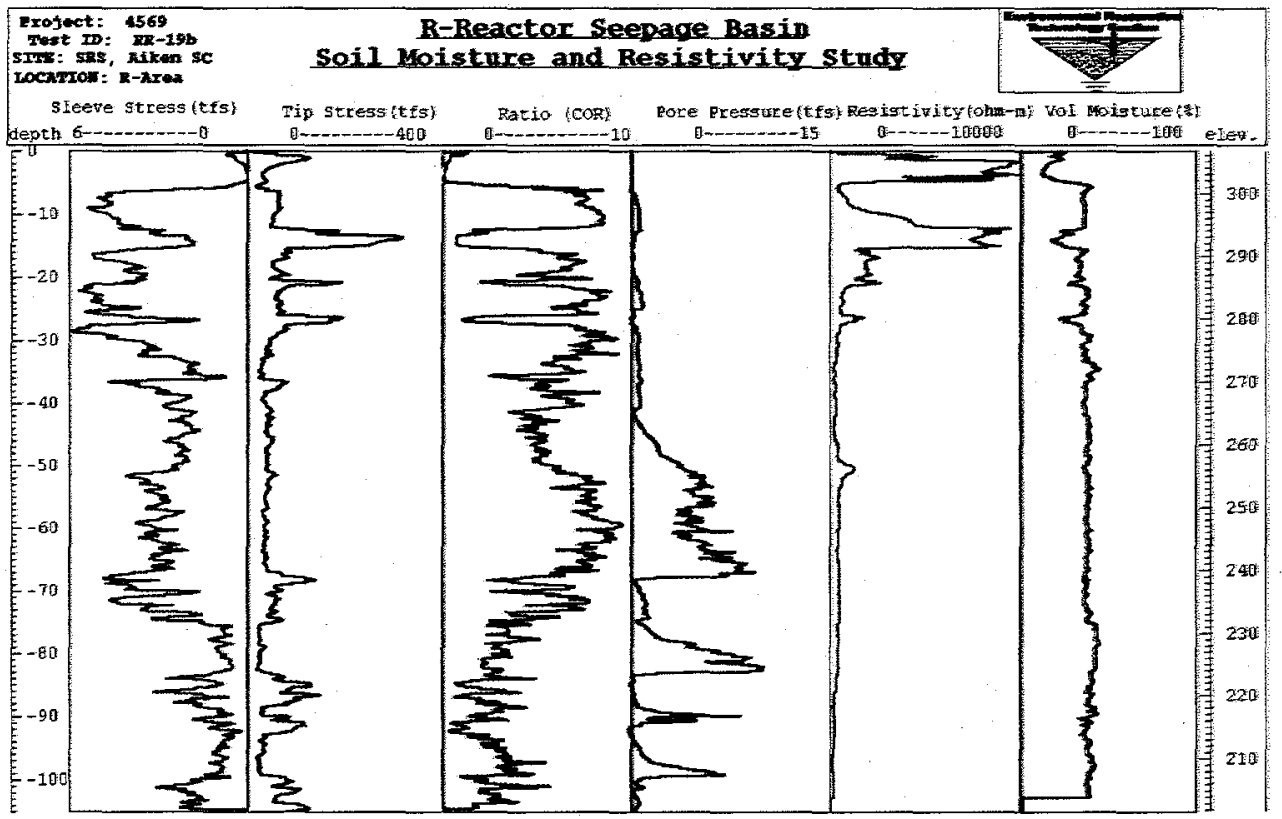

RR-19B 
Appendix C - Shelby Tube Sample Results 
This page intentionally left blank

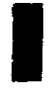

I
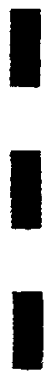

I

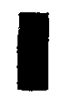

I

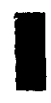

I

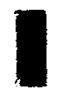


July 23, 1999

Westinghouse Savannah River Company

P.O. Box 616

Aiken, South Carolina 29808

Attention: $\quad$ Mr. Bruce Triplett

Building 730-2B, Room 1086

Subcontract No. AB80111N

Subject:Transmittal of Test Results: r-Reactor Seepage Basin Perch Water Geotechnical Testing Services

WSRC Site Wide - Task Release No.41

Dear Mr. Triplett:

Law Engineering Project No. 50161-7-0108 (Phase 41)

Law Engineering and Environmental Services, Inc. has completed the assigned laboratory tests for Task Release No. 41 of our 3-year site-wide geotechnical testing contract. We are transmitting to you the tabular and/or graphical summary for each of the specimens tested. A copy of the Laboratory Assignment Sheet is enclosed with the samples tested These are the final results, thus, we have enclosed two copies of the following test results for your distribution:

Grain Size Wash200 (ASTM D422)

Unit Weight and Porosity (EM1110-2-1906)

If you have any questions pertaining to these test results or require additional information, please do not hesitate to call us.

Sincerely,

LAW ENGINEERNG and ENVIRONMENTAL SERVICES, INC.

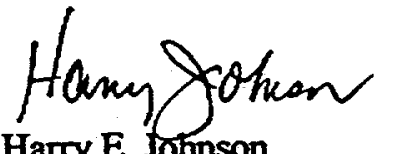

Harry E. Johnson.

Principal Technician 


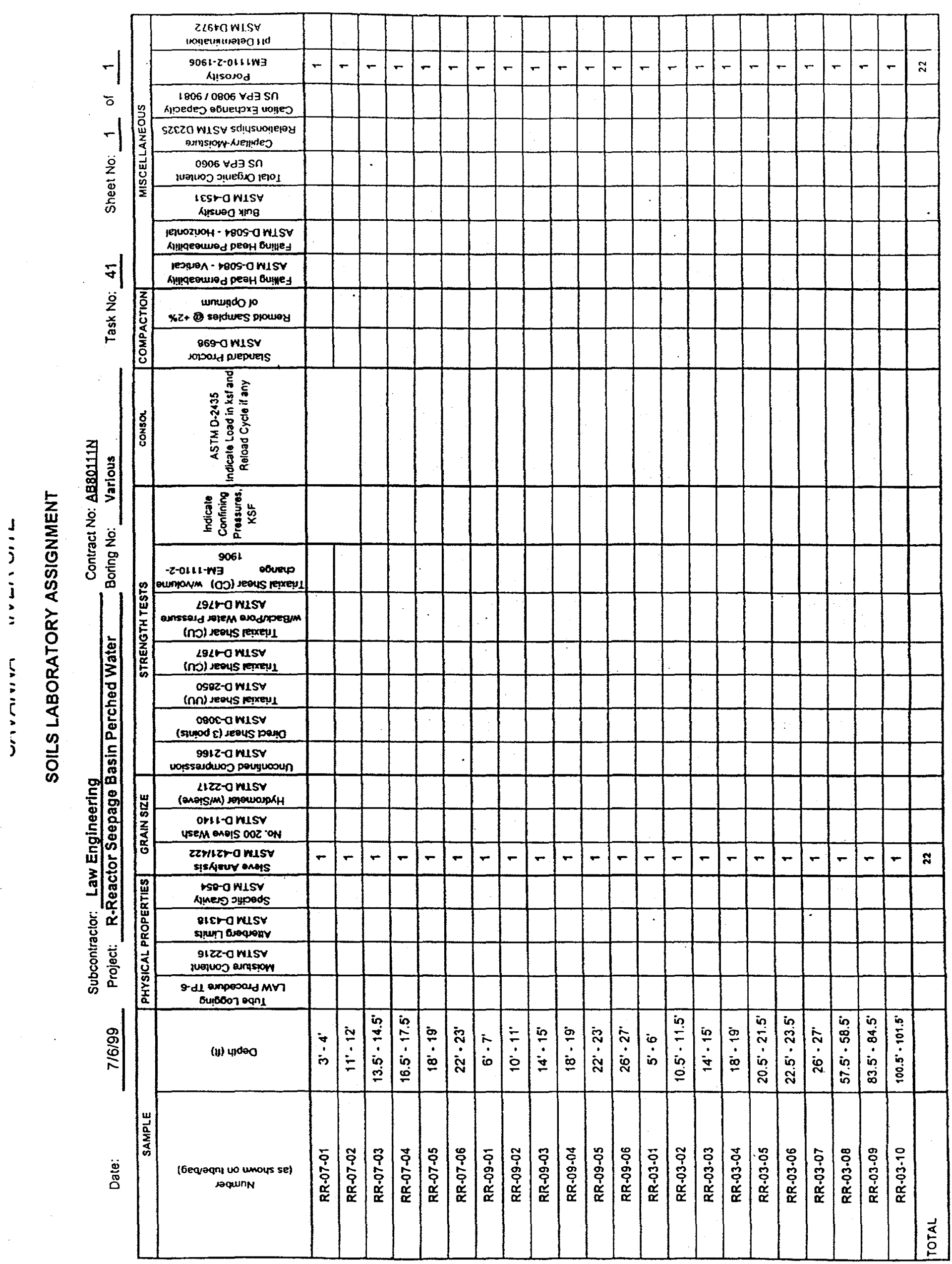




\section{LAWGIBB}

\section{TP-4A: UNIT WEIGHT OF SAMPLE}

Project No: $50161-7-0108$

Phase:

Task: 41

Project Name: $\overline{\text { R-Reactor Seepage Basin Perched }}$

Tested By: SC

Date: $07 / 07 / 99$
Boring No.: RR-07-01

Depth: 3-4 Ft.

Sample ID: Ud

Reviewed By: HEJ

Date: $07 / 18 / 99$

\begin{tabular}{|c|c|c|c|c|c|c|}
\hline \multicolumn{2}{|c|}{$\begin{array}{l}\text { Total Sample } \\
\text { Hejght, inches }\end{array}$} & \multicolumn{2}{|c|}{$\begin{array}{c}\text { Inside Diameter } \\
\text { of Cut Tube, inches }\end{array}$} & \multicolumn{3}{|c|}{ Moisture Content } \\
\hline 1 & 12.14 & \multirow{3}{*}{$\begin{array}{r}\text { Top } \\
\text { Bottom }\end{array}$} & \multirow[b]{2}{*}{1.409} & Tare No. & $C-22$ & \multirow[b]{2}{*}{ grams } \\
\hline 2 & 12.1 & & & Tare Weight & 15.68 & \\
\hline 3 & 12.12 & & 1.409 & Wet Weight + Tare & 214.71 & grams \\
\hline \multirow[t]{2}{*}{$\overline{\text { Average }}$} & 12.12 & \multirow[t]{2}{*}{ Average } & 1.409 & Dry Weight + Tare & 182.79 & grams \\
\hline & & & & Moisture Content & 19.1 & $\%$ \\
\hline
\end{tabular}

\begin{tabular}{|lcl|}
\hline Total Weight of Soil + Tube Section & 626.20 & grams \\
\cline { 2 - 3 } Weight of Clean, Dry Tube Section & 63.78 & grams \\
\cline { 2 - 3 } Wet Weight of Soil & 1.24 \\
Volume of Sample & 0.011 & $\mathrm{ft}^{3}$ \\
\hline
\end{tabular}

RESULT SUMMARY

\begin{tabular}{|l|}
\hline $\begin{array}{l}\text { Moisture Content } \\
\text { Wet Density }\end{array}$ \\
$\begin{array}{l}\text { Dry Density } \\
\text { Specific Gravity } \\
\text { Porosity }\end{array}$ \\
\hline$\frac{113.1}{\frac{95.2}{2.64}}$ pcf \\
\hline
\end{tabular}




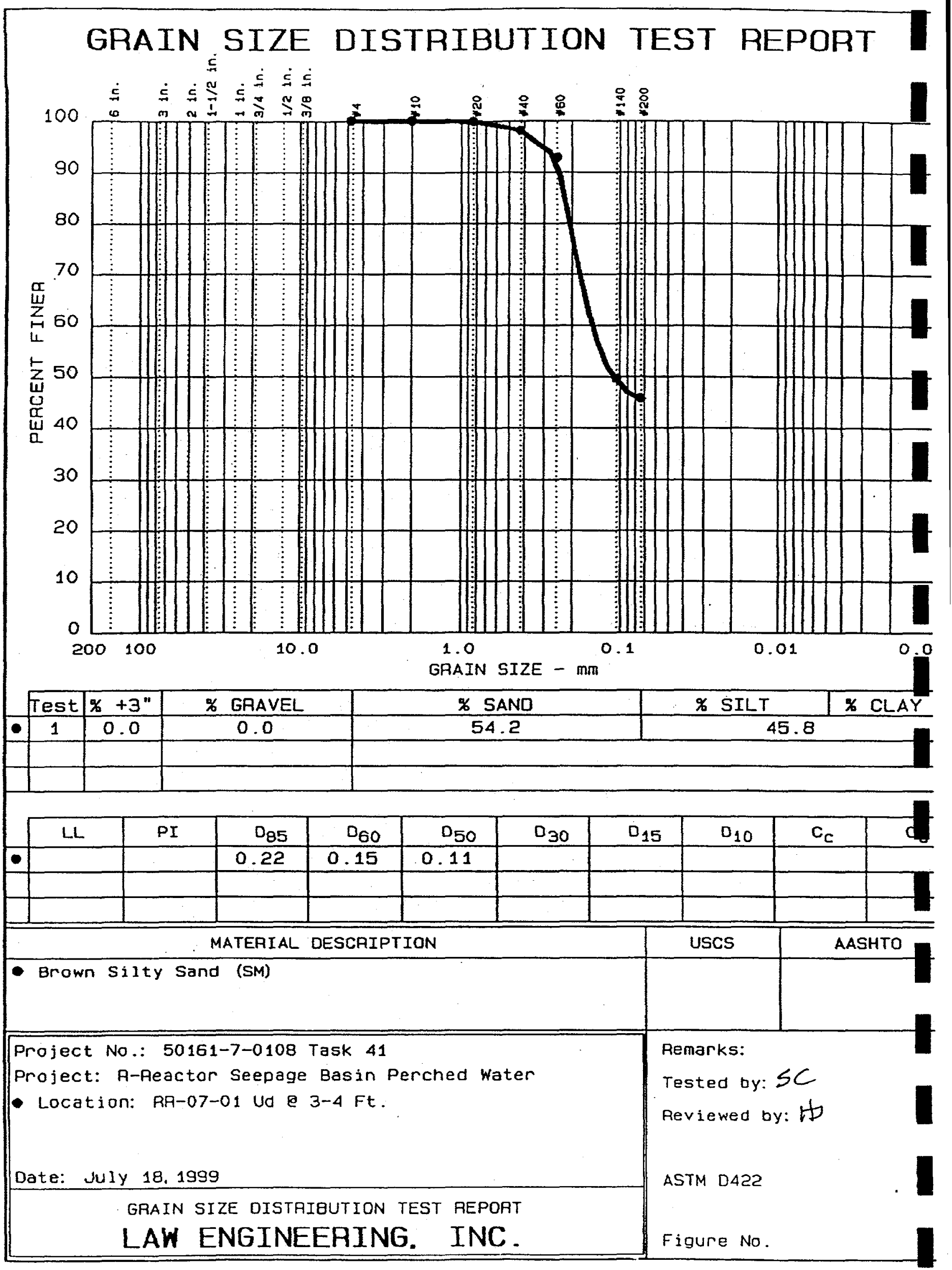




\section{LAWGIBB}

\section{TP-4A: UNIT WEIGHT OF SAMPLE}

Project No.: 50161-7-0108

Phase:

Task: 41

Project Name: $\overline{\text { R-Reactor Seepage Basin Perched }}$

Tested By: SC

Date: $07 / 07 / 99$
Boring No.: RR-07-02

Depth: $11-12 \mathrm{Ft}$.

Sample ID: Ud

Reviewed By: HEJ

Date: $07 / 18 / 99$

\begin{tabular}{|c|c|c|c|c|c|c|}
\hline \multicolumn{2}{|c|}{$\begin{array}{l}\text { Total Sample } \\
\text { Hejght, inches }\end{array}$} & \multicolumn{2}{|c|}{$\begin{array}{c}\text { Inside Diameter } \\
\text { of Cut Tube, inches }\end{array}$} & \multicolumn{3}{|c|}{ Moisture Content } \\
\hline 1 & 12 & \multirow{3}{*}{$\begin{array}{r}\text { Top } \\
\text { Bottom } \\
\end{array}$} & \multirow[b]{2}{*}{1.404} & Tare No. & $\mathrm{V}-53$ & \multirow{3}{*}{$\begin{array}{l}\text { grams } \\
\text { grams }\end{array}$} \\
\hline 2 & 11.95 & & & Tare Weight & 16.48 & \\
\hline 3 & 11.95 & & 1.405 & Wet Weight + Tare & 152.51 & \\
\hline \multirow[t]{2}{*}{ Average } & 11.97 & \multirow[t]{2}{*}{ Average } & 1.405 & Dry Weight + Tare & 137.44 & grams \\
\hline & & & & Moisture Content & 12.5 & $\%$ \\
\hline
\end{tabular}

\begin{tabular}{|lcl|}
\hline Total Weight of Soil + Tube Section & 613.48 & grams \\
\cline { 2 - 3 } Weight of Clean, Dry Tube Section & 62.89 & grams \\
\cline { 2 - 3 } & 1.21 & lbs \\
Wet Weight of Soil & 0.011 & $\mathrm{ft}^{3}$ \\
\hline
\end{tabular}

RESULT SUMMARY

\begin{tabular}{|c|c|c|}
\hline Moisture Content & 12.5 & $\%$ \\
\hline Wet Density & 113.1 & $p c f$ \\
\hline Dry Density & 100.6 & $p c f$ \\
\hline Specific Gravity & 2.65 & \\
\hline Porosity & 0.39 & \\
\hline
\end{tabular}




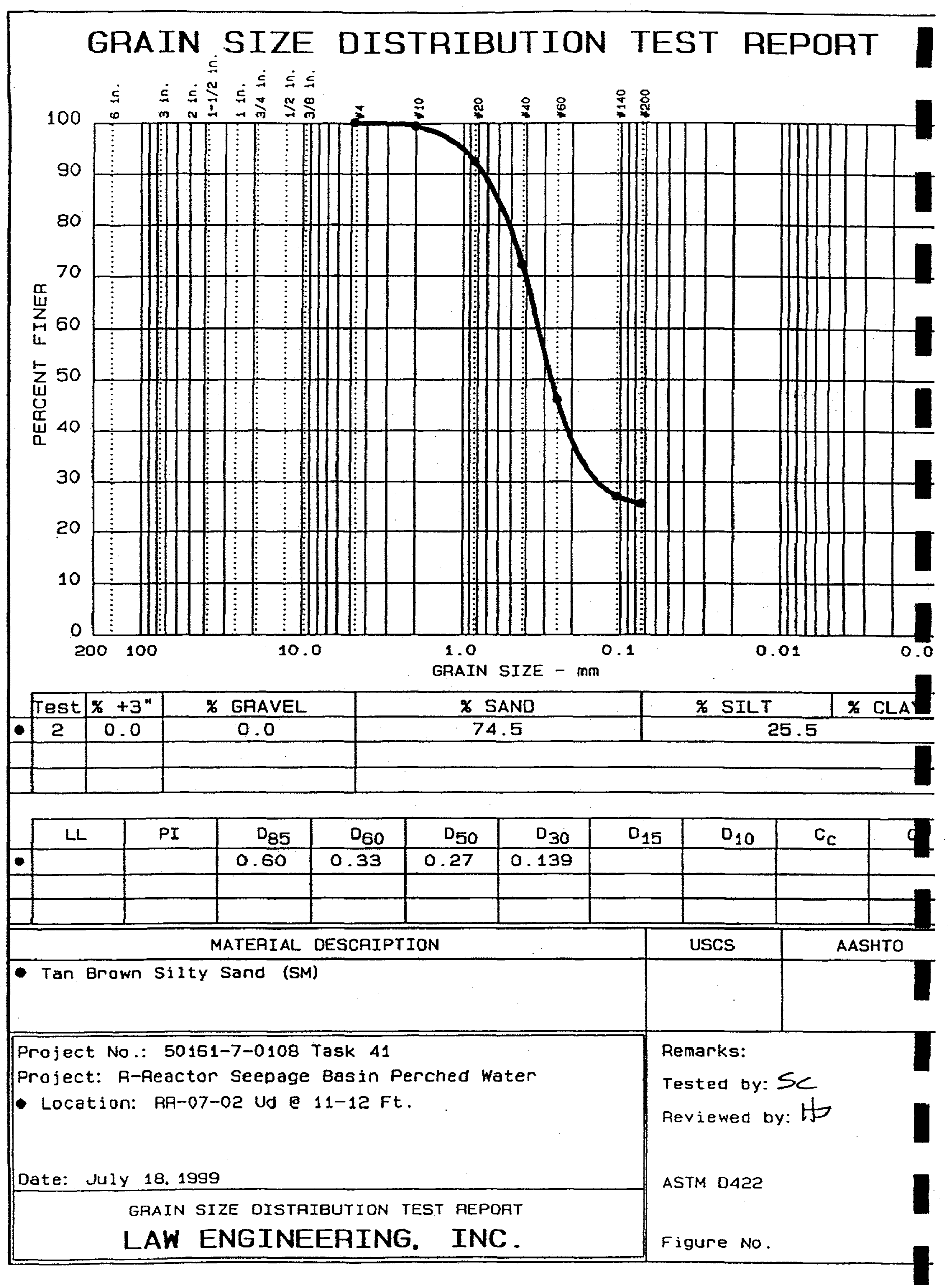




\section{LAWGIBB}

\section{TP-4A: UNIT WEIGHT OF SAMPLE}

Project No.: 50161-7-0108

Phase:

Task: 41

Project Name: R-Reactor Seepage Basin Perched

Tested By: $\overline{\mathrm{SC}}$

Date: $07 / 07 / 99$
Boring No.: RR-07-03

Depth: $13.5-14.5 \mathrm{Ft}$.

Sample ID: Ud

Reviewed By: $\mathrm{HEJ}$

Date: $07 / 18 / 99$

\begin{tabular}{|c|c|c|c|c|c|c|}
\hline \multicolumn{2}{|c|}{$\begin{array}{l}\text { Total Sample } \\
\text { Height, inches } \\
\end{array}$} & \multicolumn{2}{|c|}{$\begin{array}{c}\text { Inside Diameter } \\
\text { of Cut Tube, inches } \\
\end{array}$} & \multicolumn{3}{|c|}{ Moisture Content } \\
\hline 1 & 12.4 & \multirow{3}{*}{$\begin{array}{l}\text { Top } \\
\text { Bottom }\end{array}$} & \multirow[b]{2}{*}{1.407} & Tare No. & $D-4$ & \multirow{3}{*}{$\begin{array}{l}\text { grams } \\
\text { grams }\end{array}$} \\
\hline 2 & 12.4 & & & Tare Weight & 14.44 & \\
\hline 3 & 12.42 & & 1.407 & Wet Weight + Tare & 187.56 & \\
\hline Average & 12.41 & Average & 1.407 & $\begin{array}{r}\text { Dry Weight + Tare } \\
\text { Moisture Content }\end{array}$ & $\frac{170.69}{10.8}$ & $\begin{array}{l}\text { grams } \\
\%\end{array}$ \\
\hline
\end{tabular}

\begin{tabular}{|lcl|}
\hline Total Weight of Soil + Tube Section & 598.90 & grams \\
\cline { 2 - 3 } Weight of Clean, Dry Tube Section & 65.04 & grams \\
\cline { 2 - 3 } Wet Weight of Soil & 1.18 & lbs \\
\cline { 2 - 3 } & 0.011 & $\mathrm{ft}^{3}$ \\
\hline
\end{tabular}

\section{RESULT SUMMARY}

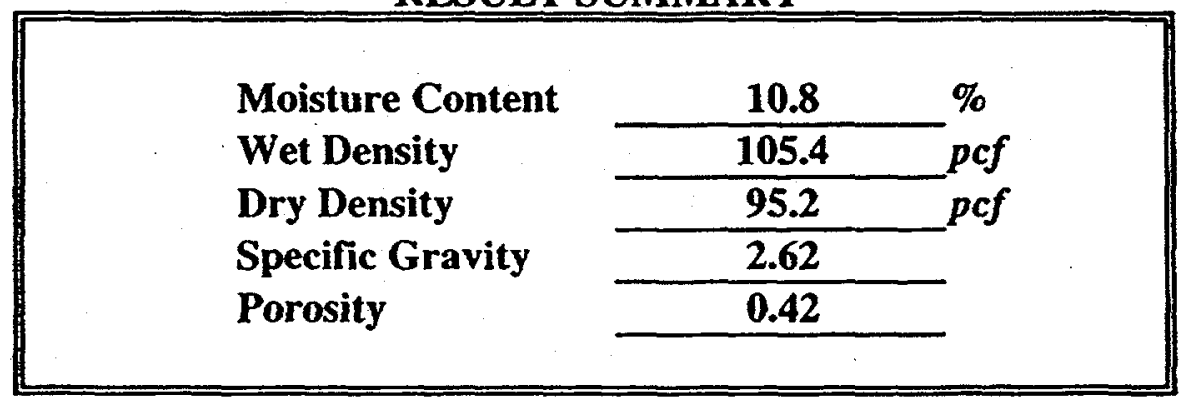




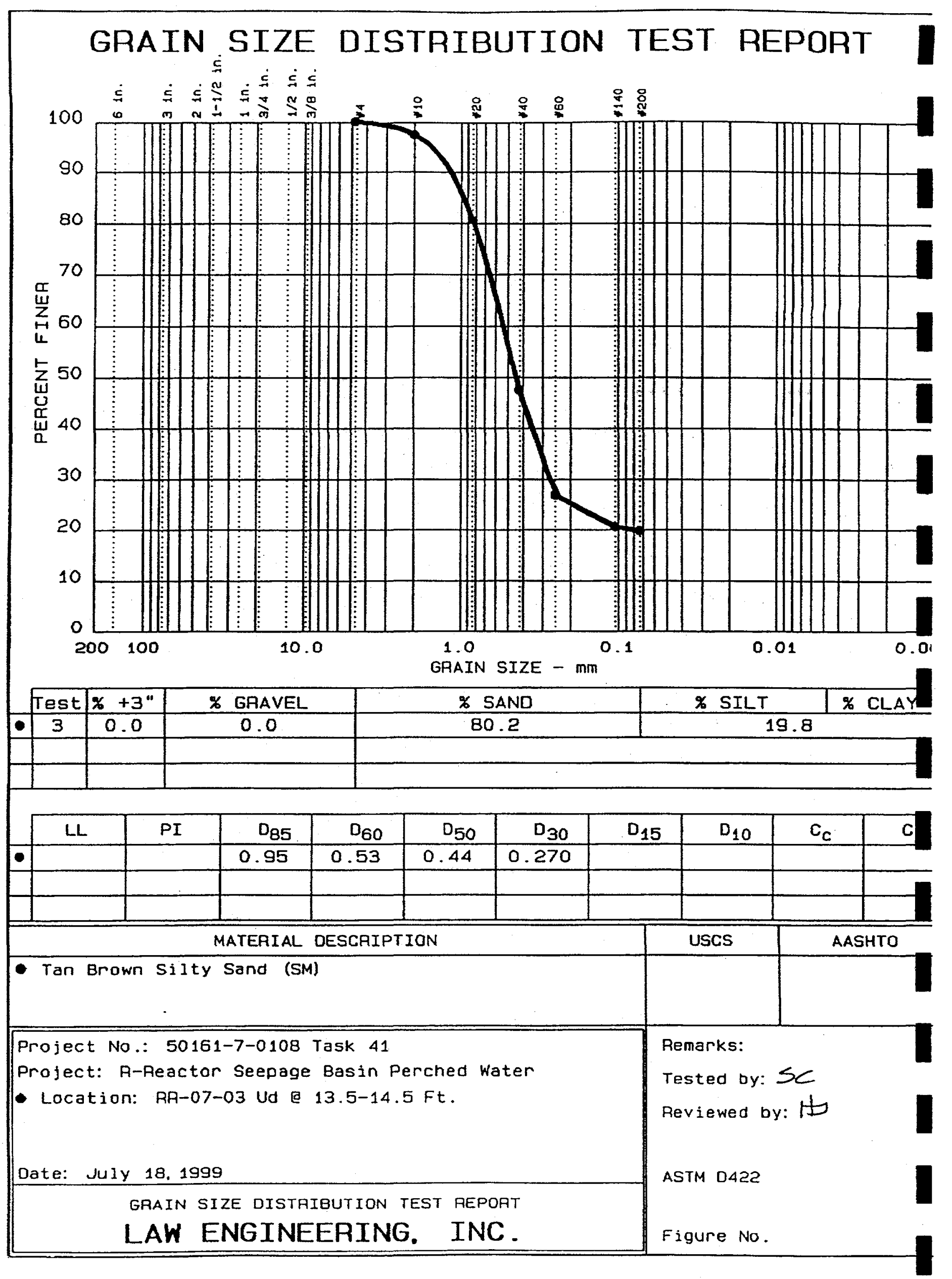




\section{LAWGIBB}

\section{TP-4A: UNIT WEIGHT OF SAMPLE}

Project No.: 50161-7-0108

Phase:

Task: 41

Project Name: R-Reactor Seepage Basin Perched

Tested By: SC

Date: $07 / 07 / 99$
Boring No.: RR-07-04

Depth: $16.5-17.5 \mathrm{Ft}$.

Sample ID: Ud

Reviewed By: HEJ

Date: $07 / 18 / 99$

\begin{tabular}{|c|c|c|c|c|c|c|}
\hline \multicolumn{2}{|c|}{$\begin{array}{l}\text { Total Sample } \\
\text { Height, inches }\end{array}$} & \multicolumn{2}{|c|}{$\begin{array}{c}\text { Inside Diameter } \\
\text { of Cut Tube, inches }\end{array}$} & \multicolumn{3}{|c|}{ Moisture Content } \\
\hline 1 & 11.72 & \multirow{3}{*}{$\begin{array}{r}\text { Top } \\
\text { Bottom }\end{array}$} & \multirow[b]{2}{*}{1.401} & Tare No. & $C-31$ & \multirow{3}{*}{$\begin{array}{l}\text { grams } \\
\text { grams }\end{array}$} \\
\hline 2 & 11.73 & & & Tare Weight & 16.24 & \\
\hline 3 & 11.74 & & 1.400 & Wet Weight + Tare & 175.70 & \\
\hline Average & 11.73 & Average & 1.401 & Dry Weight + Tare & $\frac{155.21}{117}$ & grams \\
\hline
\end{tabular}

\begin{tabular}{|lcl|}
\hline Total Weight of Soil + Tube Section & 558.10 & grams \\
\cline { 2 - 3 } Weight of Clean, Dry Tube Section & 66.36 & grams \\
\cline { 2 - 3 } & 1.08 & lbs \\
Wet Weight of Soil & 0.010 & $\mathrm{ft}^{3}$ \\
\hline
\end{tabular}

\section{RESULT SUMMARY}

\begin{tabular}{|l|}
\hline $\begin{array}{l}\text { Moisture Content } \\
\text { Wet Density }\end{array}$ \\
$\begin{array}{l}\text { Dry Density } \\
\text { Specific Gravity } \\
\text { Porosity }\end{array}$ \\
\hline
\end{tabular}




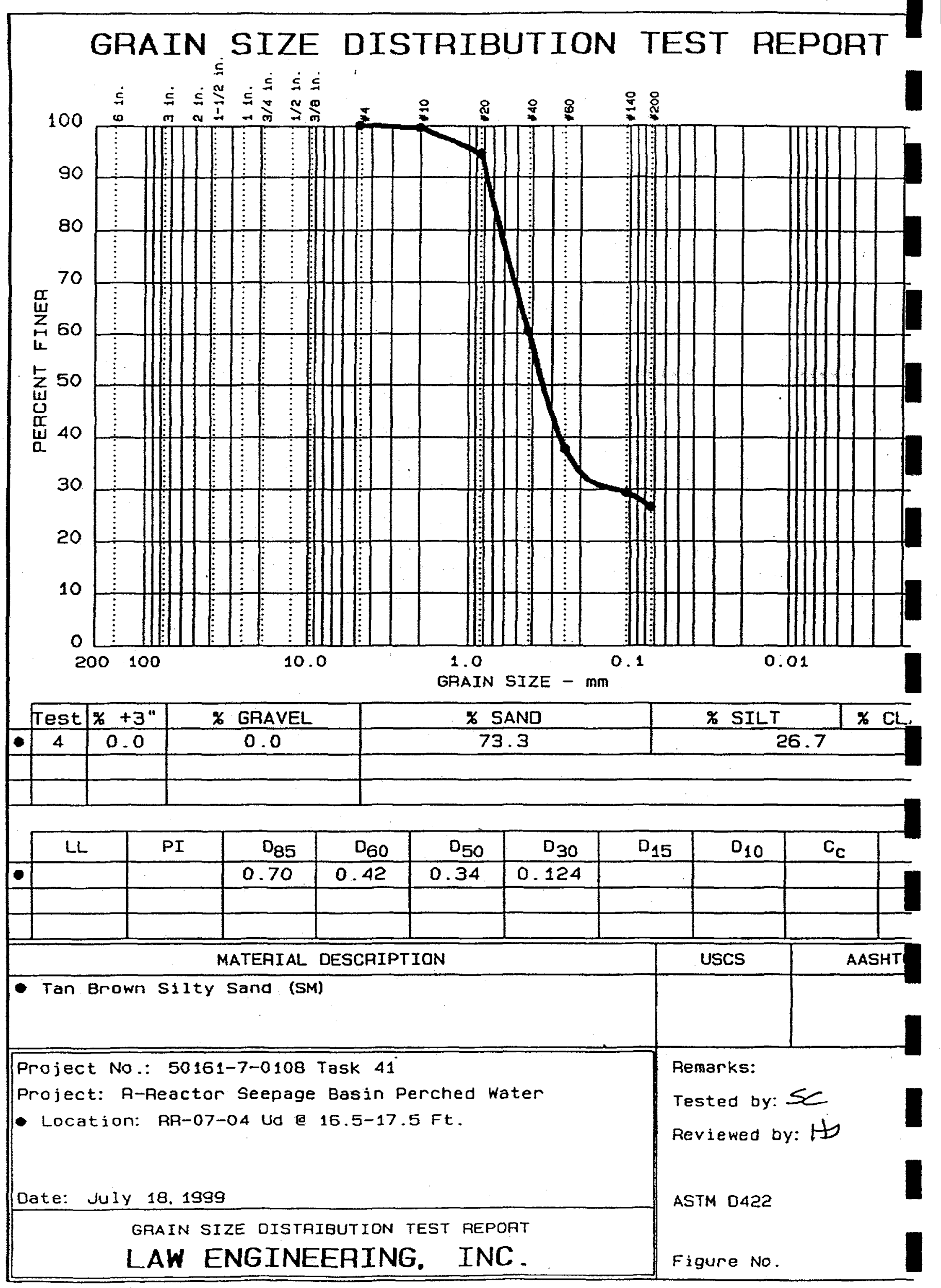




\section{$\frac{\text { LAWGIBB }}{\text { GROUP }}$}

\section{TP-4A: UNIT WEIGHT OF SAMPLE}

Project No.: 50161-7-0108

Phase:

Task: 41

Project Name: $\overline{\text { R-Reactor Seepage Basin Perched }}$

Tested By: SC

Date: 07/07/99
Boring No.: RR-07-05

Depth: 18-19 Ft.

Sample ID: Ud

Reviewed By: HEJ

Date: $07 / 18 / 99$

\begin{tabular}{|c|c|c|c|c|c|c|}
\hline \multicolumn{2}{|c|}{$\begin{array}{l}\text { Total Sample } \\
\text { Height, inches }\end{array}$} & \multicolumn{2}{|c|}{$\begin{array}{l}\text { Inside Diameter } \\
\text { of Cut Tube, inches }\end{array}$} & \multicolumn{3}{|c|}{ Moisture Content } \\
\hline 1 & 12.07 & & & Tare No. & $\mathrm{R}-64$ & \\
\hline 2 & 12.05 & Top & 1.395 & Tare Weight & 16.02 & grams \\
\hline 3 & 12.1 & Bottom & 1.395 & Wet Weight + Tare & 214.28 & grams \\
\hline Average & 12.07 & Average & 1.395 & $\begin{array}{l}\text { Dry Weight + Tare } \\
\text { Moisture Content }\end{array}$ & $\frac{181.50}{19.8}$ & $\begin{array}{l}\text { grams } \\
\%\end{array}$ \\
\hline
\end{tabular}

\begin{tabular}{|lcr|}
\hline Total Weight of Soil + Tube Section & 588.60 & grams \\
Weight of Clean, Dry Tube Section & 68.52 & grams \\
\cline { 2 - 3 } & 1.15 & lbs \\
Wet Weight of Soil & 0.011 & $\mathrm{ft}^{3}$ \\
\hline
\end{tabular}

\section{RESULT SUMMARY}

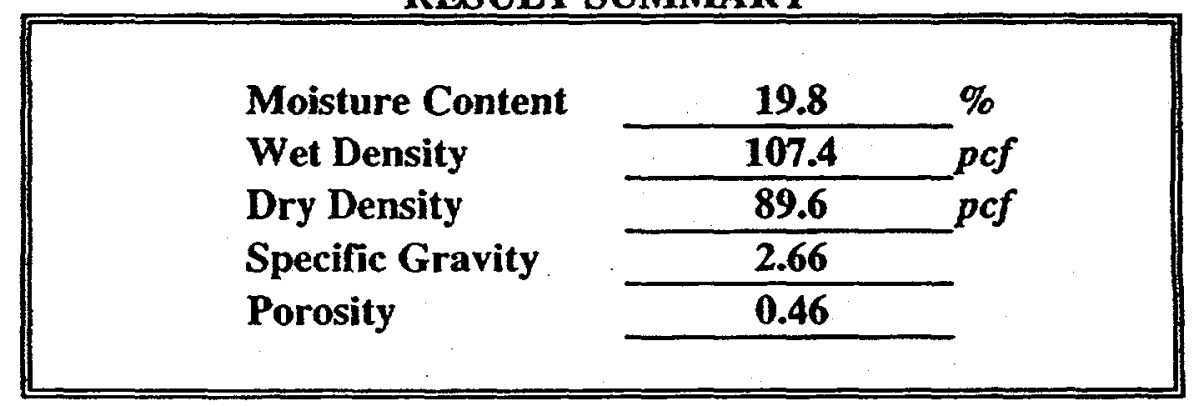




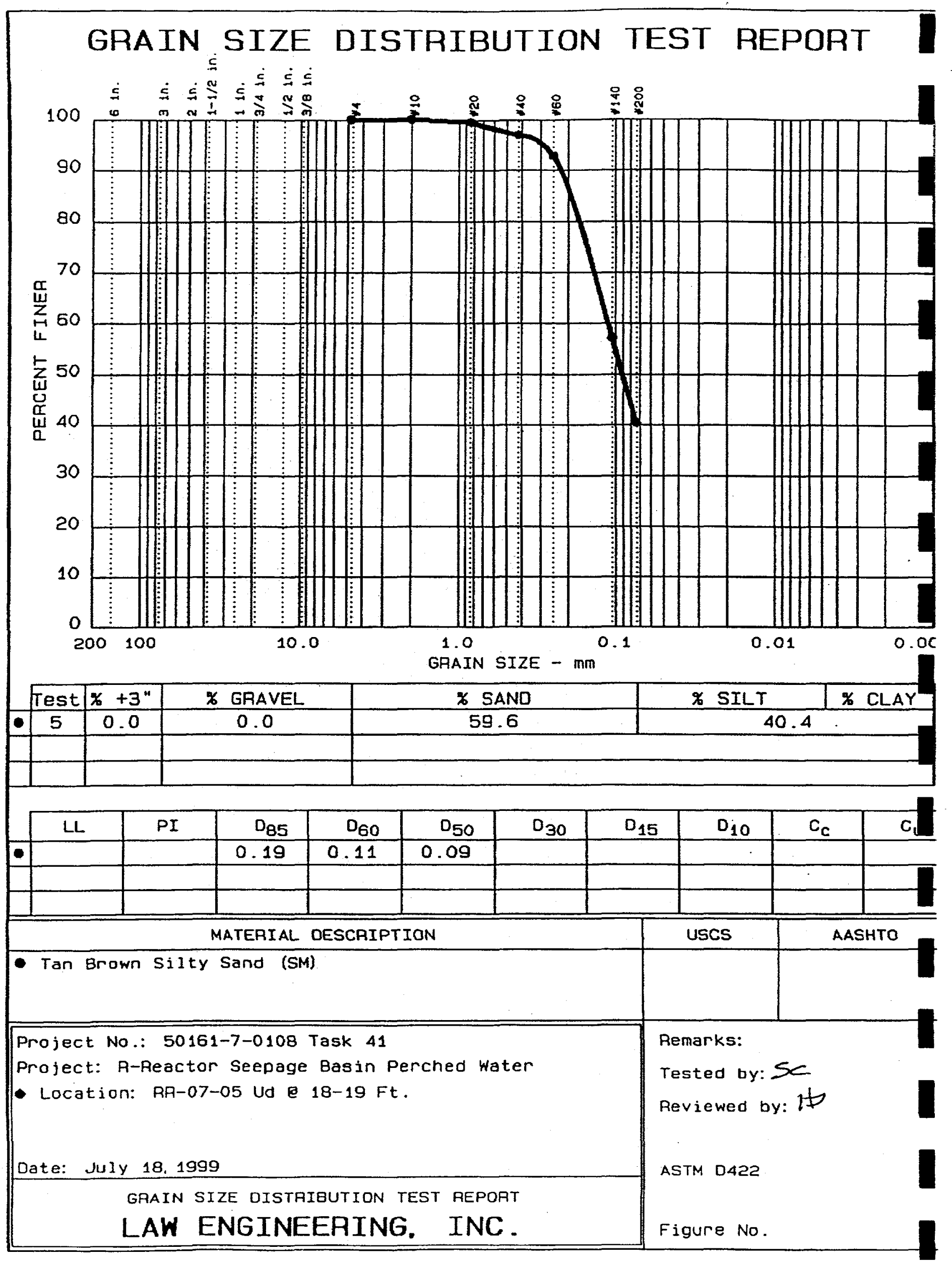




\section{LAWGIBB}

\section{TP-4A: UNIT WEIGHT OF SAMPLE}

Project No.: 50161-7-0108

Phase:

Task: 41

Project Name: R-Reactor Seepage Basin Perched

Tested By: SC

Date: $07 / 07 / 99$
Boring No.: RR-07-06

Depth: 22-23 Ft.

Sample ID: Ud

Reviewed By: HEJ

Date: $07 / 18 / 99$

\begin{tabular}{|c|c|c|c|c|c|c|}
\hline \multicolumn{2}{|c|}{$\begin{array}{l}\text { Total Sample } \\
\text { Height, inches }\end{array}$} & \multicolumn{2}{|c|}{$\begin{array}{l}\text { Inside Diameter } \\
\text { of Cut Tube, inches }\end{array}$} & \multicolumn{3}{|c|}{ Moisture Content } \\
\hline$\overline{1}$ & 12.15 & \multirow{3}{*}{$\begin{array}{r}\text { Top } \\
\text { Bottom }\end{array}$} & \multirow[b]{2}{*}{1.400} & Tare No. & $V-13$ & \multirow{3}{*}{$\begin{array}{l}\text { grams } \\
\text { grams }\end{array}$} \\
\hline 2 & 12.03 & & & Tare Weight & 15.49 & \\
\hline 3 & 12.04 & & 1.400 & Wet Weight + Tare & 211.05 & \\
\hline Average & 12.07 & Average & 1.400 & $\begin{array}{l}\text { Dry Weight + Tare } \\
\text { Moisture Content }\end{array}$ & $\frac{186.95}{14.1}$ & $\begin{array}{l}\text { grams } \\
\%\end{array}$ \\
\hline
\end{tabular}

\begin{tabular}{|lll|}
\hline Total Weight of Soil + Tube Section & 564.50 & grams \\
\cline { 2 - 3 } Weight of Clean, Dry Tube Section & 68.60 & grams \\
\cline { 2 - 3 } & 1.09 & ${ }^{\text {lbs }}$ \\
Wet Weight of Soil & 0.011 & $\mathrm{ft}^{3}$ \\
\hline
\end{tabular}

\section{RESULT SUMMARY}

\begin{tabular}{|l||}
\hline Moisture Content \\
Wet Density \\
$\begin{array}{l}\text { Dry Density } \\
\text { Specific Gravity } \\
\text { Porosity }\end{array}$ \\
\cline { 2 - 2 } \\
\cline { 2 - 2 }
\end{tabular}




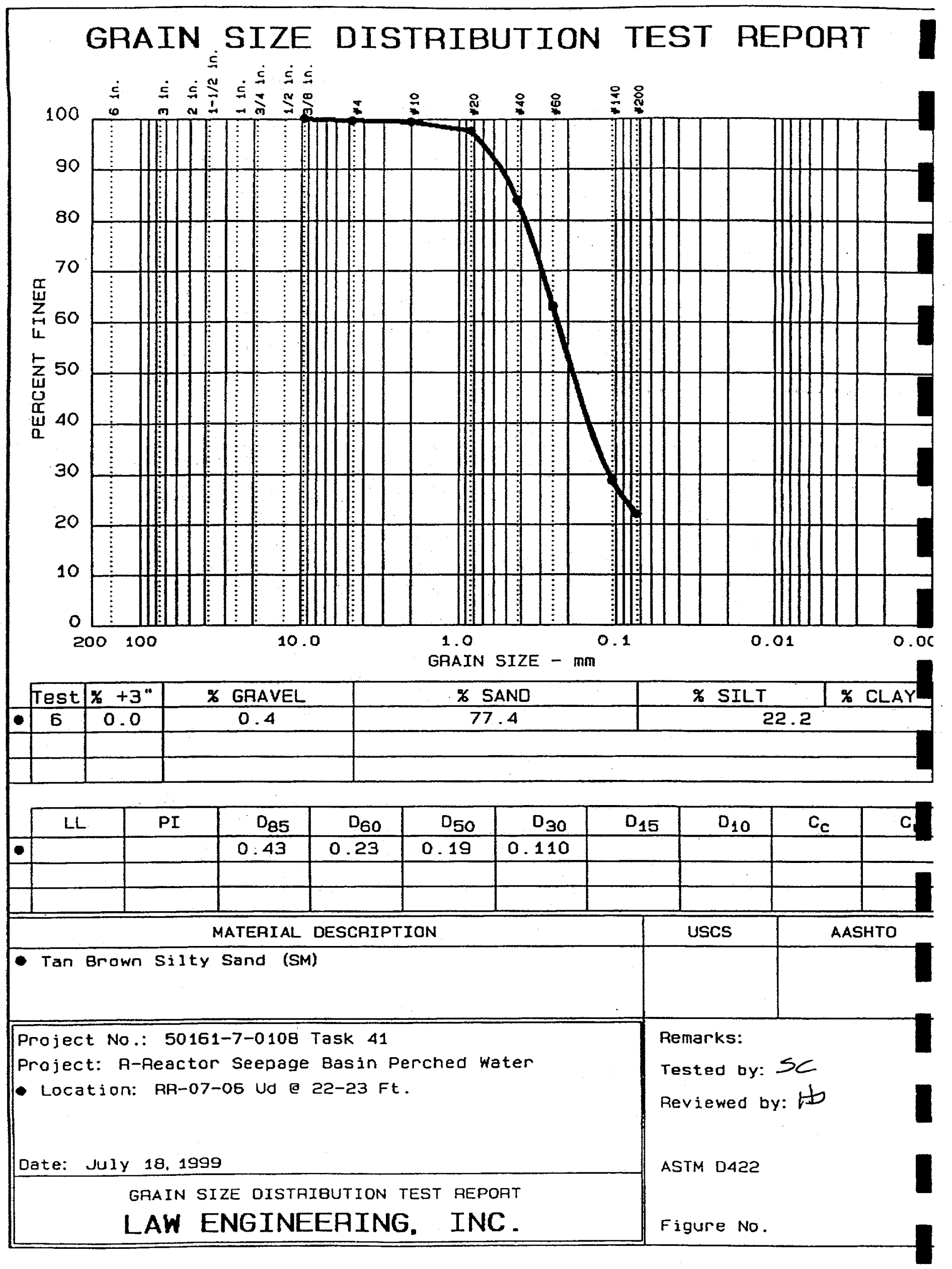




\section{LAWGIBB}

\section{TP-4A: UNIT WEIGHT OF SAMPLE}

Project No.: 50161-7-0108

Phase:

Task: 41

Project Name: R-Reactor Seepage Basin Perched

Tested By: SC

Date: $07 / 07 / 99$
Boring No.: RR-09-01

Depth: 6-7 Ft.

Sample ID: Ud

Reviewed By: $\mathrm{HEJ}$

Date: $07 / 18 / 99$

\begin{tabular}{|c|c|c|c|c|c|c|}
\hline \multicolumn{2}{|c|}{$\begin{array}{l}\text { Total Sample } \\
\text { Height, inches }\end{array}$} & \multicolumn{2}{|c|}{$\begin{array}{l}\text { Inside Diameter } \\
\text { of Cut Tube, inches }\end{array}$} & \multicolumn{3}{|c|}{ Moisture Content } \\
\hline 1 & 11.91 & \multirow{3}{*}{$\begin{array}{l}\text { Top } \\
\text { 3ottom }\end{array}$} & \multirow[b]{2}{*}{1.401} & Tare No. & $\overline{C-23}$ & \multirow{3}{*}{$\begin{array}{l}\text { grams } \\
\text { grams }\end{array}$} \\
\hline 2 & 11.91 & & & Tare Weight & 16.70 & \\
\hline 3 & 11.94 & & 1.402 & Wet Weight + Tare & 171.05 & \\
\hline \multirow[t]{2}{*}{ Average } & 11.92 & \multirow[t]{2}{*}{ Average } & \multirow[t]{2}{*}{1.402} & Dry Weight + Tare & 156.05 & \multirow{2}{*}{$\begin{array}{l}\text { grams } \\
\%\end{array}$} \\
\hline & & & & Moisture Content & 10.8 & \\
\hline
\end{tabular}

\begin{tabular}{|c|c|c|}
\hline Total Weight of Soil + Tube Section & 553.20 & grams \\
\hline Weight of Clean, Dry Tube Section & 63.22 & grams \\
\hline Wet Weight of Soil & 1.08 & lbs \\
\hline Volume of Sample & 0.011 & $f t^{3}$ \\
\hline
\end{tabular}

RESULT SUMMARY

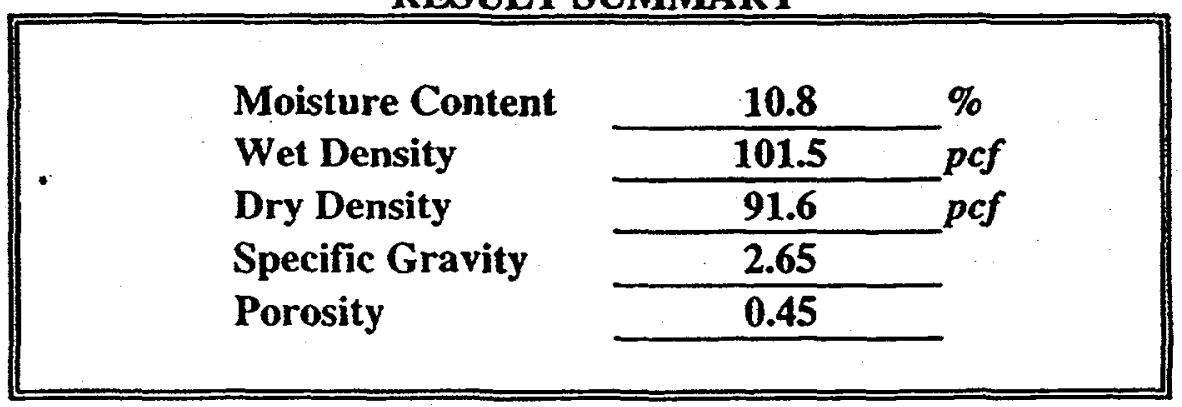




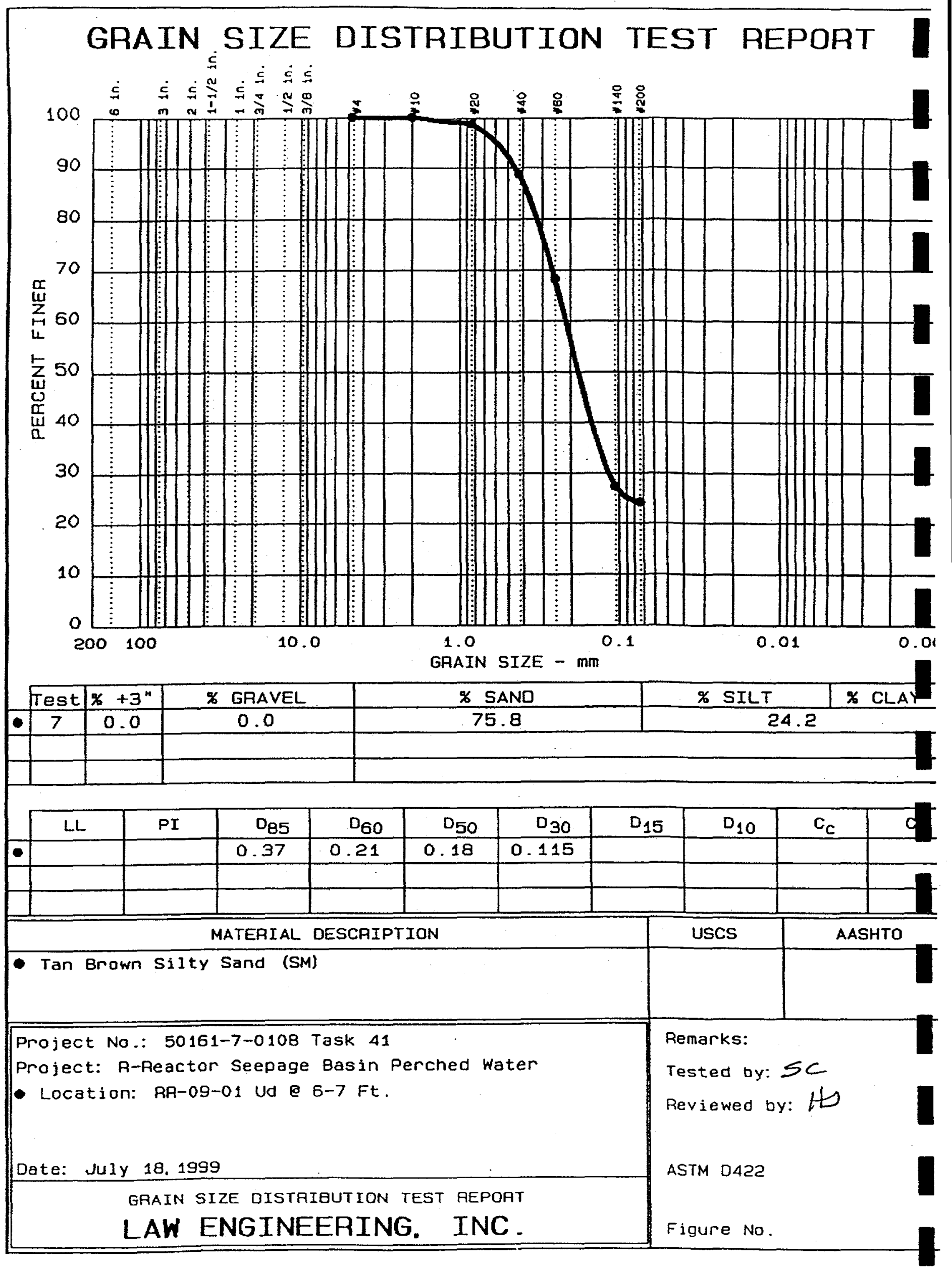




\section{LAWGIBB}

\section{TP-4A: UNIT WEIGHT OF SAMPLE}

Project No.: 50161-7-0108

Phase:

Task: 41

Project Name: $\overline{\text { R-Reactor Seepage Basin Perched }}$

Tested By: SC

Date: $07 / 07 / 99$
Boring No.: RR-09-02

Depth: $10-11 \mathrm{Ft}$.

Sample ID: Ud

Reviewed By: HEJ

Date: $07 / 18 / 99$

\begin{tabular}{|c|c|c|c|c|c|c|}
\hline \multicolumn{2}{|c|}{$\begin{array}{l}\text { Total Sample } \\
\text { Height inches }\end{array}$} & \multicolumn{2}{|c|}{$\begin{array}{l}\text { Inside Diameter } \\
\text { of Cut Tube, inches }\end{array}$} & \multicolumn{3}{|c|}{ Moisture Content } \\
\hline 1 & 12.15 & \multirow{3}{*}{$\begin{array}{r}\text { Top } \\
\text { Bottom }\end{array}$} & \multirow[b]{2}{*}{1.410} & Tare No. & P-13 & \multirow[b]{2}{*}{ grams } \\
\hline 2 & 12.17 & & & Tare Weight & 15.25 & \\
\hline 3 & 12.2 & & 1.410 & Wet Weight + Tare & 233.39 & grams \\
\hline Average & 12.17 & Average & 1.410 & Dry Weight + Tare & 202.87 & grams \\
\hline
\end{tabular}

\section{RESULT SUMMARY}

\begin{tabular}{|c|c|c|}
\hline Moisture Content & 16.3 & $\%$ \\
\hline Wet Density & 117.2 & $p c f$ \\
\hline Dry Density & 100.8 & $p c f$ \\
\hline Specific Gravity & 2.66 & \\
\hline Porosity & 0.39 & \\
\hline
\end{tabular}




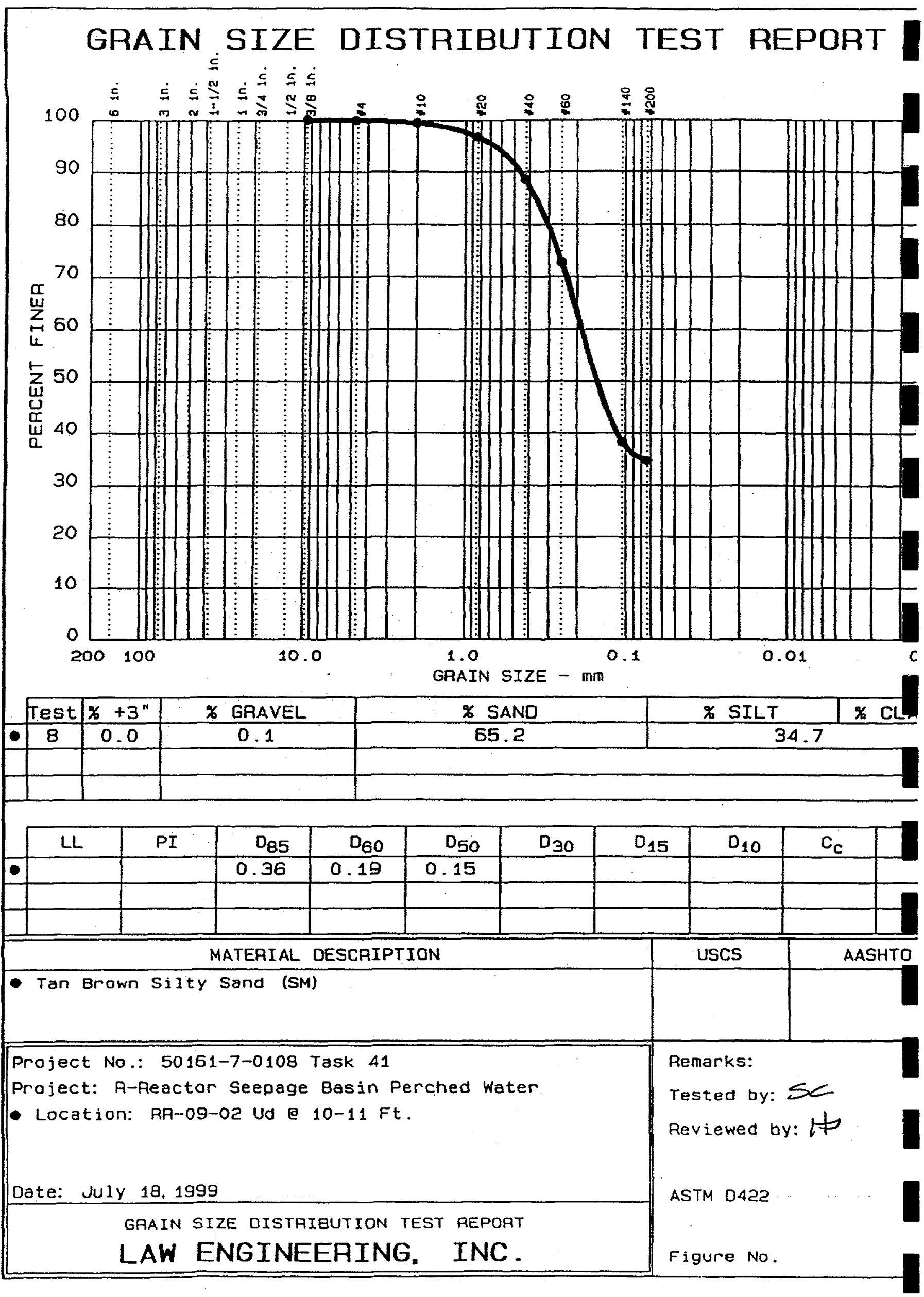




\section{LAWGIBB}

\section{TP-4A: UNIT WEIGHT OF SAMPLE}

Project No.: 50161-7-0108

Phase:

Task: 41

Project Name: $\overline{\text { R-Reactor Seepage Basin Perched }}$

Tested By: SC

Date: $07 / 07 / 99$
Boring No.: RR-09-03

Depth: 14-15 Ft.

Sample ID: Ud

Reviewed By: HEJ

Date: $07 / 18 / 99$

\begin{tabular}{|c|c|c|c|c|c|c|}
\hline \multicolumn{2}{|c|}{$\begin{array}{l}\text { Total Sample } \\
\text { Height, inches }\end{array}$} & \multicolumn{2}{|c|}{$\begin{array}{c}\text { Inside Diameter } \\
\text { of Cut Tube, inches }\end{array}$} & \multicolumn{3}{|c|}{ Moisture Content } \\
\hline 1 & 12.12 & \multirow{3}{*}{$\begin{array}{l}\text { Top } \\
\text { Bottom }\end{array}$} & \multirow[b]{2}{*}{1.403} & Tare No. & C-37 & \multirow[b]{2}{*}{ grams } \\
\hline 2 & 12.14 & & & Tare Weight & 15.99 & \\
\hline 3 & 12.16 & & 1.400 & Wet Weight + Tare & 187.69 & grams \\
\hline \multirow[t]{2}{*}{ Average } & 12.14 & \multirow[t]{2}{*}{ Average } & 1.402 & Dry Weight + Tare & 150.47 & grams \\
\hline & & & & Moisture Content & 27.7 & \\
\hline
\end{tabular}

\begin{tabular}{|lcr|}
\hline Total Weight of Soil + Tube Section & 607.20 & grams \\
\cline { 2 - 3 } Weight of Clean, Dry Tube Section & 64.07 & grams \\
\cline { 2 - 3 } Wet Weight of Soil & 1.20 & lbs \\
Volume of Sample & 0.011 & $\mathrm{ft}^{3}$ \\
\hline
\end{tabular}

RESULT SUMMARY

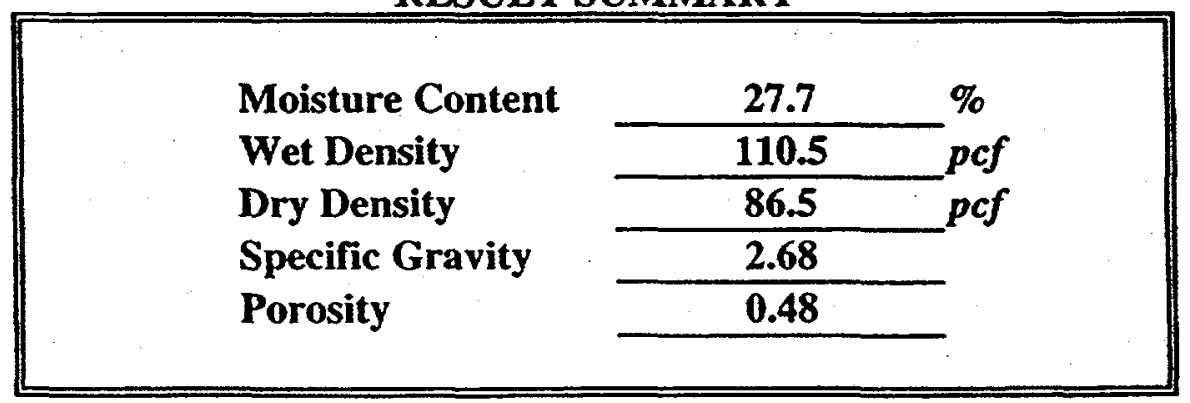




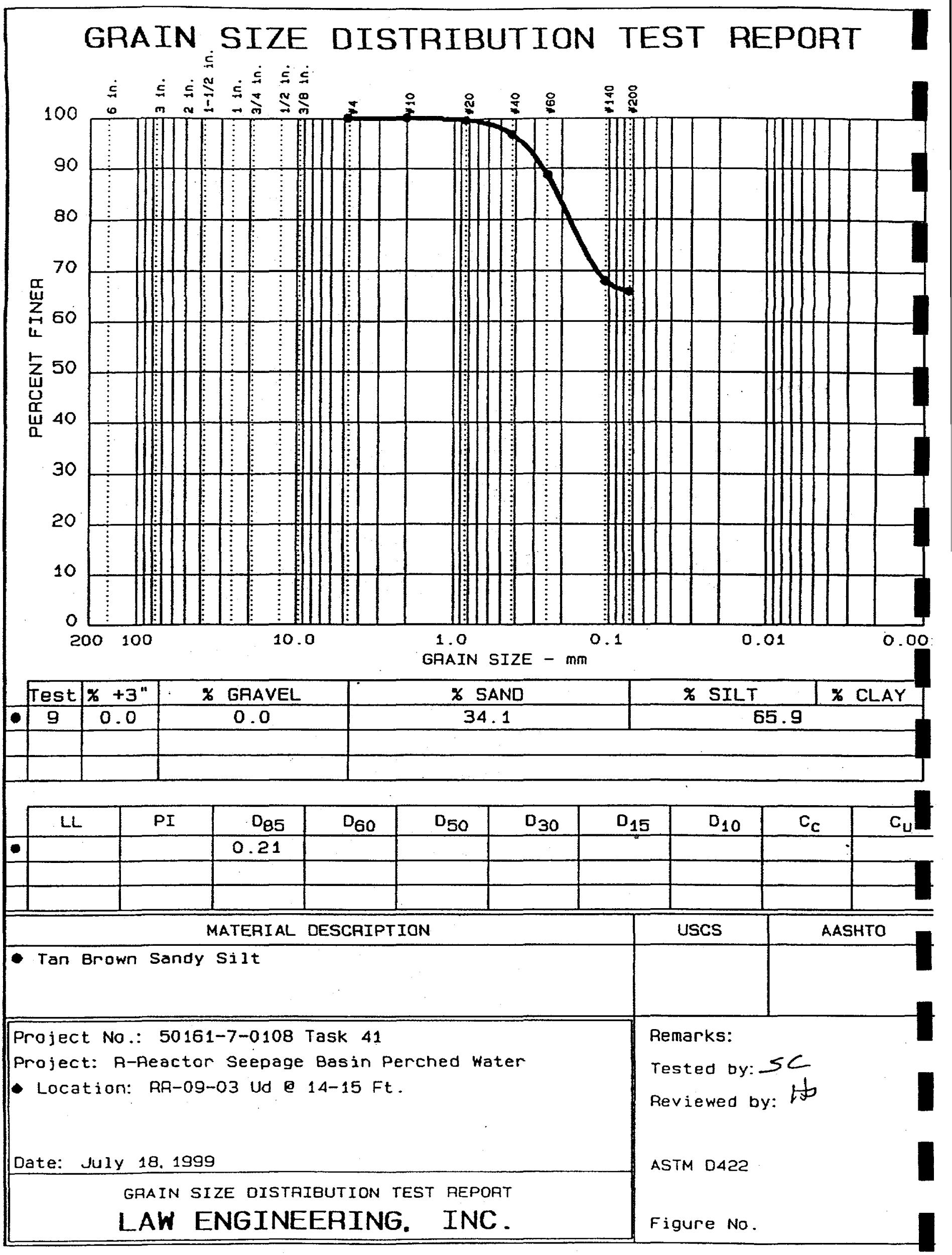




\section{LAWGIBB}

\section{TP-4A: UNIT WEIGHT OF SAMPLE}

Project No.: 50161-7-0108

Phase:

Task: 41

Project Name: R-Reactor Seepage Basin Perched Tested By: $\overline{\mathrm{SC}}$

Date: $07 / 07 / 99$
Boring No.: RR-09-04

Depth: 18-19 Ft.

Sample ID: Ud

Reviewed By: $\mathrm{HEJ}$

Date: $07 / 18 / 99$

\begin{tabular}{|c|c|c|c|c|c|c|}
\hline \multicolumn{2}{|c|}{$\begin{array}{l}\text { Total Sample } \\
\text { Height, inches }\end{array}$} & \multicolumn{2}{|c|}{$\begin{array}{l}\text { Inside Diameter } \\
\text { of Cut Tube, inches }\end{array}$} & \multicolumn{3}{|c|}{ Moisture Content } \\
\hline 1 & 12.22 & & & Tare No. & $\mathrm{C}-7$ & \\
\hline 2 & 12.2 & Top & 1.410 & Tare Weight & 16.57 & grams \\
\hline 3 & 12.16 & Bottom & 1.410 & Wet Weight + Tare & 237.03 & grams \\
\hline Average & 12.19 & Average & 1.410 & $\begin{array}{l}\text { Dry Weight }+ \text { Tare } \\
\text { Moisture Content }\end{array}$ & $\frac{201.75}{19.1}$ & $\begin{array}{l}\text { grams } \\
\%\end{array}$ \\
\hline
\end{tabular}

Total Weight of Soil + Tube Section

Weight of Clean, Dry Tube Section

Wet Weight of Soil

\begin{tabular}{cc}
\hline 625.60 & grams \\
\hline 63.77 & grams \\
\hline 1.24 & lbs \\
\hline 0.011 & $f^{3}$ \\
\hline
\end{tabular}

RESULT SUMMARY

\begin{tabular}{|l|}
\hline \\
Moisture Content \\
Wet Density \\
$\begin{array}{l}\text { Dry Density } \\
\text { Specific Gravity } \\
\text { Porosity }\end{array}$ \\
\cline { 2 - 2 } \\
\cline { 2 - 2 } \\
\cline { 2 - 2 }
\end{tabular}




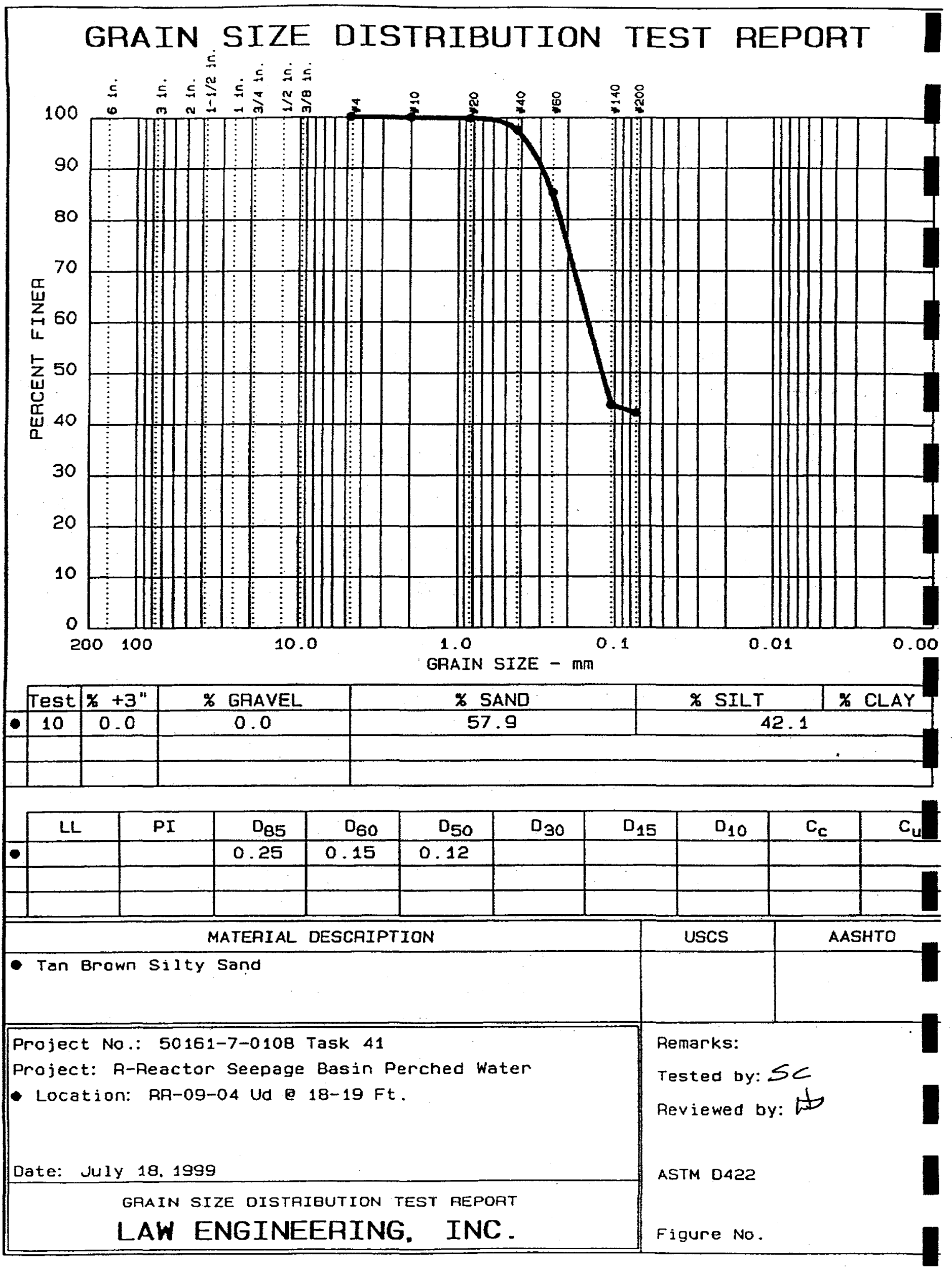




\section{$\frac{\text { LAWGIBB }}{\text { GROUP }}$}

\section{TP-4A: UNIT WEIGHT OF SAMPLE}

Project No.: 50161-7-0108

Phase:

Task: 41

Project Name: $\overline{R-R e a c t o r ~ S e e p a g e ~ B a s i n ~ P e r c h e d ~}$

Tested By: $\overline{\mathrm{SC}}$

Date: $07 / 07 / 99$
Boring No.: RR-09-05

Depth: 22-23 Ft.

Sample ID: Ud

Reviewed By: HEJ

Date: $07 / 18 / 99$

\begin{tabular}{|c|c|c|c|c|c|c|}
\hline \multicolumn{2}{|c|}{$\begin{array}{l}\text { Total Sample } \\
\text { Height, inches }\end{array}$} & \multicolumn{2}{|c|}{$\begin{array}{l}\text { Inside Diameter } \\
\text { of Cut Tube, inches }\end{array}$} & \multicolumn{3}{|c|}{ Moisture Content } \\
\hline 1 & 12 & & & Tare No. & $\mathrm{R}-43$ & \\
\hline 2 & 11.98 & Top & 1.400 & Tare Weight & 16.65 & grams \\
\hline 3 & 11.98 & Bottom & 1.400 & Wet Weight + Tare & 182.32 & grams \\
\hline Average & 11.99 & Average & 1.400 & Dry Weight + Tare & $\frac{156.74}{183}$ & grams \\
\hline
\end{tabular}

\begin{tabular}{|lcr|}
\hline Total Weight of Soil + Tube Section & 622.00 & grams \\
\cline { 2 - 3 } & 62.81 & grams \\
Weight of Clean, Dry Tube Section & 1.23 & lbs \\
Wet Weight of Soil & 0.011 & $\mathrm{ft}^{3}$ \\
\hline
\end{tabular}

RESULT SUMMARY

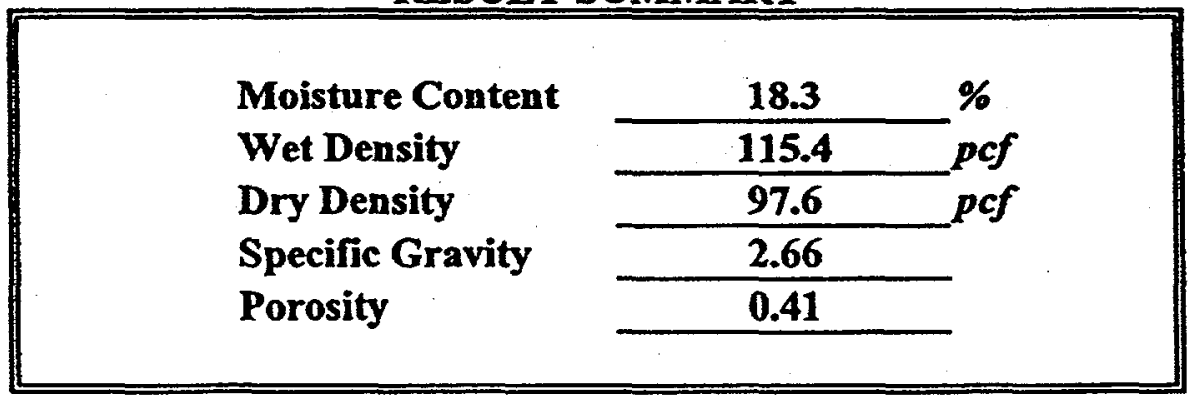




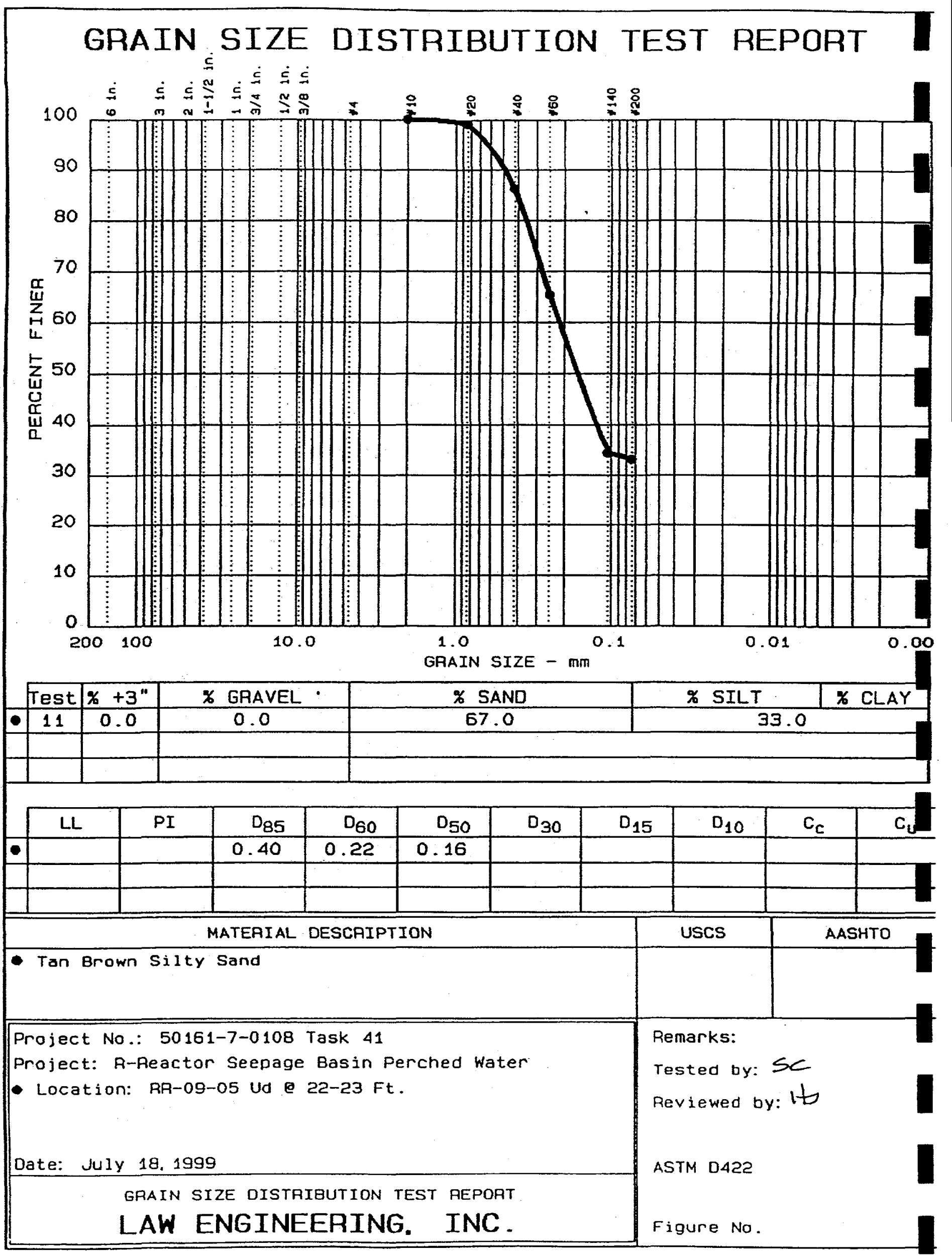




\section{LAWGIBB}

\section{TP-4A: UNIT WEIGHT OF SAMPLE}

Project No.: 50161-7-0108

Phase:

Task: 41

Project Name: $\overline{\text { R-Reactor Seepage Basin Perched }}$

Tested By: $\overline{\mathrm{SC}}$

Date: $07 / 07 / 99$
Boring No.: RR-09-06

Depth: 26-27 Ft.

Sample ID: Ud

Reviewed By: HEI

Date: $07 / 18 / 99$

\begin{tabular}{|c|c|c|c|c|c|c|}
\hline \multicolumn{2}{|c|}{$\begin{array}{l}\text { Total Sample } \\
\text { Height, inches }\end{array}$} & \multicolumn{2}{|c|}{$\begin{array}{l}\text { Inside Diameter } \\
\text { of Cut Tube, inches }\end{array}$} & \multicolumn{3}{|c|}{ Moisture Content } \\
\hline 1 & 11.96 & \multirow{3}{*}{$\begin{array}{r}\text { Top } \\
\text { Bottom }\end{array}$} & \multirow[b]{2}{*}{1.400} & Tare No. & $\mathrm{R}-35$ & \multirow{3}{*}{$\begin{array}{l}\text { grams } \\
\text { grams }\end{array}$} \\
\hline 2 & 11.95 & & & Tare Weight & 16.57 & \\
\hline 3 & 11.95 & & 1.401 & Wet Weight + Tare & 178.80 & \\
\hline \multirow[t]{2}{*}{ Average } & 11.95 & \multirow[t]{2}{*}{$\overline{\text { Average }}$} & 1.401 & Dry Weight + Tare & 155.38 & grams \\
\hline & & & & Moisture Content & 16.9 & $\%$ \\
\hline
\end{tabular}

\begin{tabular}{|lll|}
\hline Total Weight of Soil + Tube Section & 627.50 & grams \\
\cline { 2 - 3 } Weight of Clean, Dry Tube Section & 63.30 & grams \\
\cline { 2 - 3 } Wet Weight of Soil & 1.24 & lbs \\
\cline { 2 - 3 } & 0.011 & $\mathrm{ft}^{3}$ \\
\hline
\end{tabular}

\section{RESULT SUMMARY}

\begin{tabular}{|c|c|}
\hline Moisture Content & 16.9 \\
\hline Wet Density & 116.7 \\
\hline Dry Density & 99.9 \\
\hline Specific Gravity & 2.65 \\
\hline Porosity & 0.40 \\
\hline
\end{tabular}




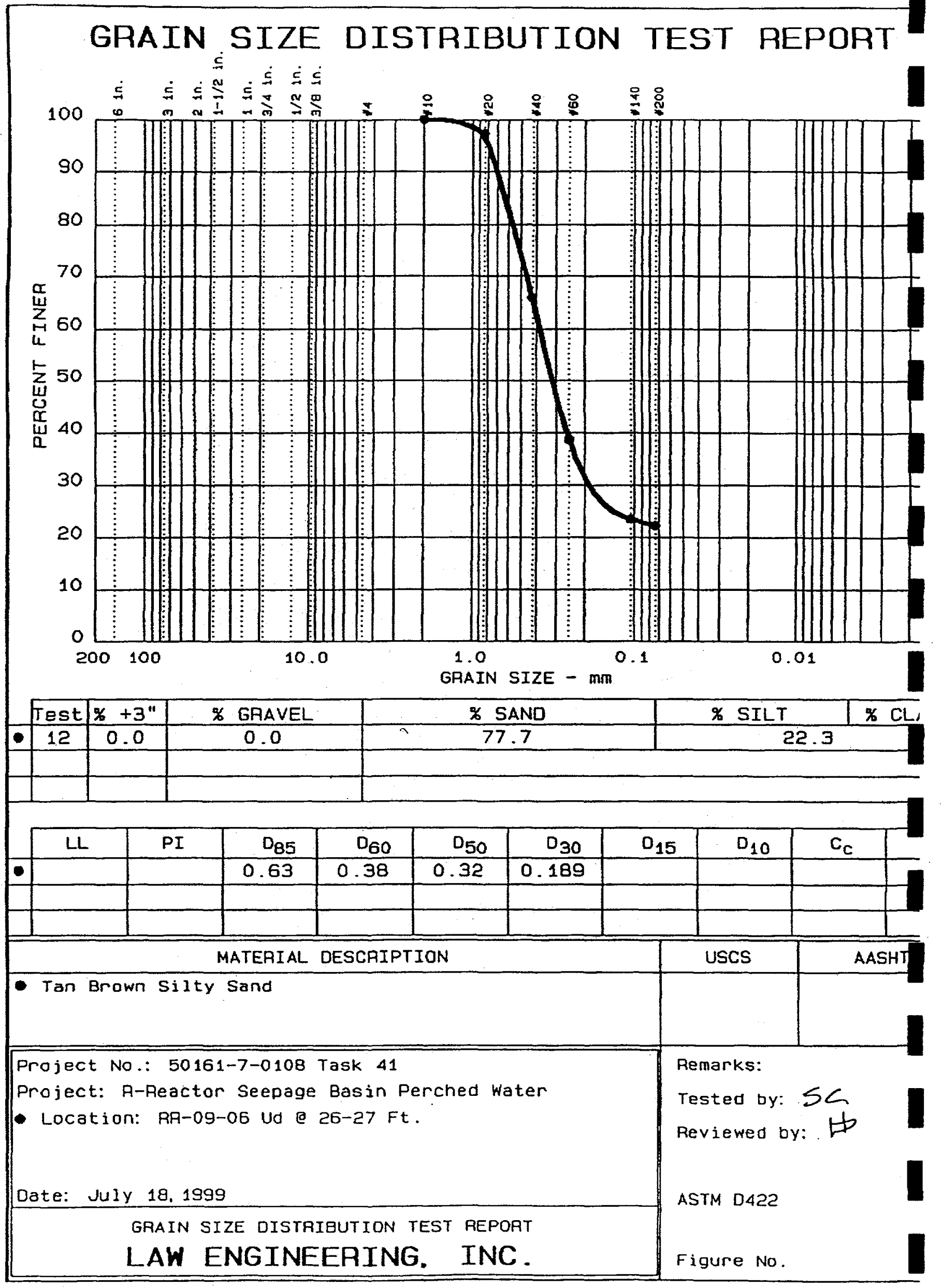




\section{$\frac{\text { LAWGIBB }}{\text { GROUP }}$}

\section{TP-4A: UNIT WEIGHT OF SAMPLE}

Project No.: 50161-7-0108

Phase:

Task: 41

Project Name: R-Reactor Seepage Basin Perched Tested By: $\mathrm{SC}$

Date: $07 / 07 / 99$
Boring No.: RR-03-01

Depth: 5-6 Ft.

Sample ID: Ud

Reviewed By: HEJ

Date: $07 / 18 / 99$

\begin{tabular}{|c|c|c|c|c|c|c|}
\hline \multicolumn{2}{|c|}{$\begin{array}{l}\text { Total Sample } \\
\text { Height, inches }\end{array}$} & \multicolumn{2}{|c|}{$\begin{array}{c}\text { Inside Diameter } \\
\text { of Cut Tube, inches }\end{array}$} & \multicolumn{3}{|c|}{ Moisture Content } \\
\hline$\overline{1}$ & 12.16 & & & Tare No. & $\overline{R-38}$ & \\
\hline 2 & 12.2 & Top & 1.398 & Tare Weight & 16.31 & grams \\
\hline 3 & 12.2 & Bottom & 1.399 & Wet Weight + Tare & 180.12 & grams \\
\hline Average & 12.19 & Average & 1.399 & Dry Weight + Tare & $\frac{166.53}{90}$ & grams \\
\hline
\end{tabular}

\begin{tabular}{lll|}
\hline Total Weight of Soil + Tube Section & 568.10 & grams \\
\cline { 2 - 3 } Weight of Clean, Dry Tube Section & 69.86 & grams \\
\cline { 2 - 3 } Wet Weight of Soil & 1.10 & $\mathrm{lbs}$ \\
\cline { 2 - 3 } & 0.011 & $\mathrm{ft}^{3}$ \\
\hline
\end{tabular}

\section{RESULT SUMMARY}

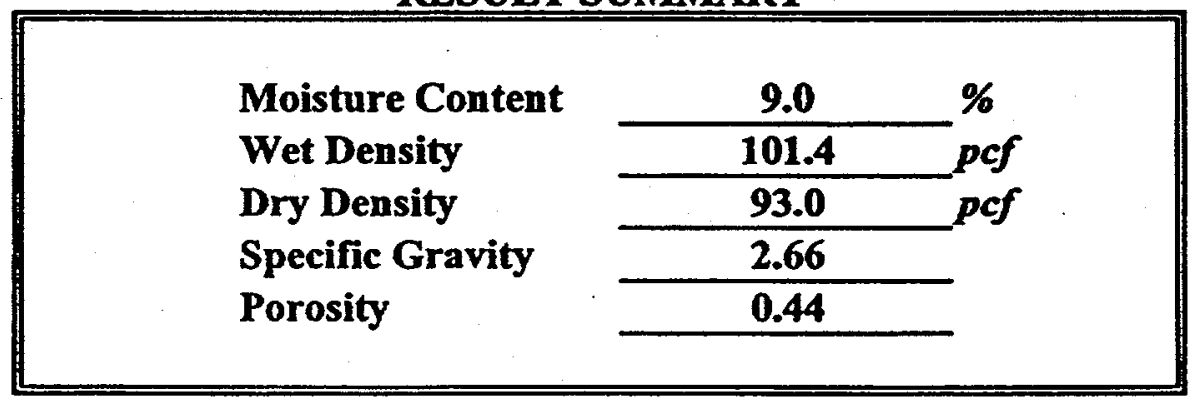




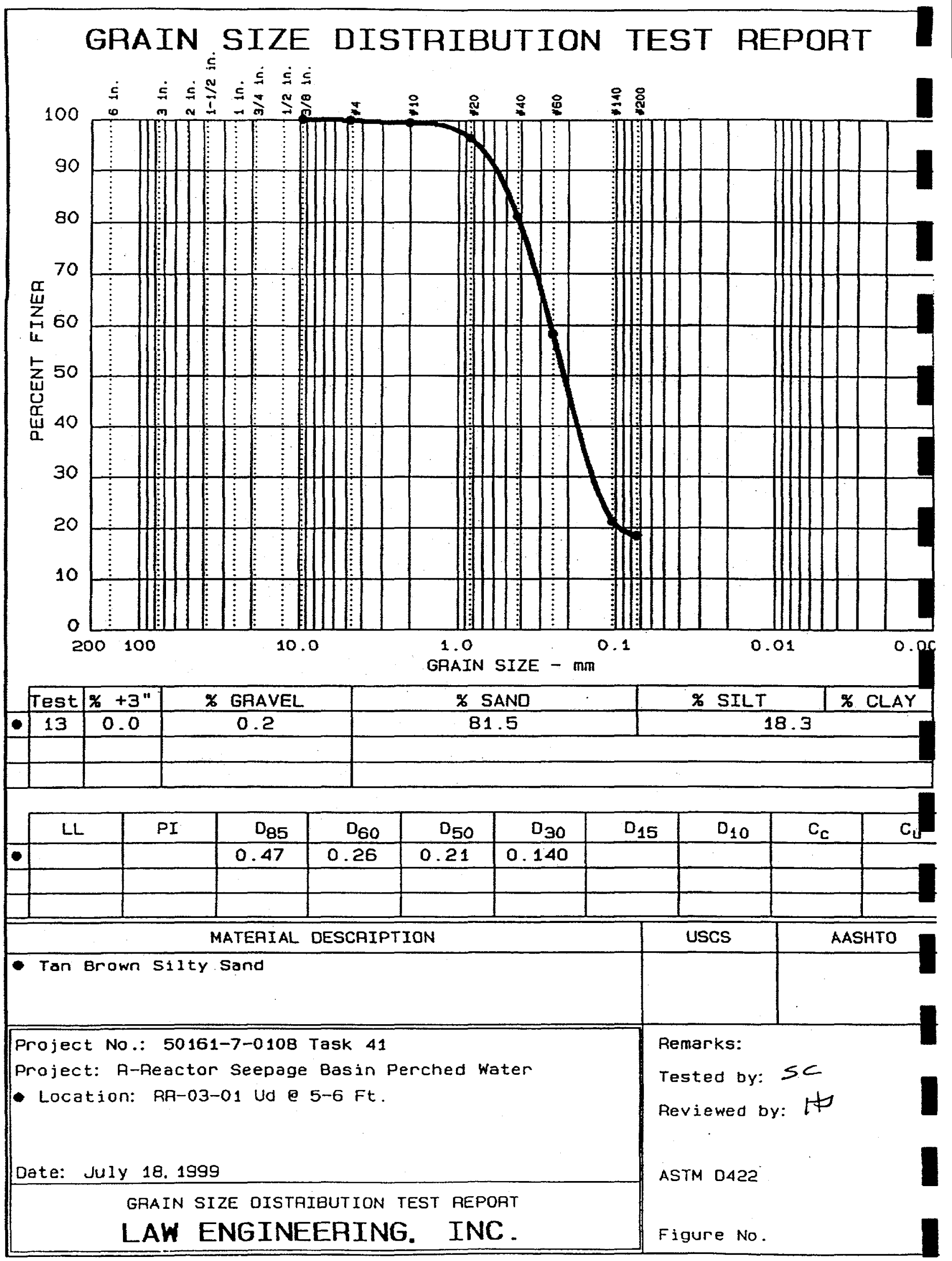




\section{LAWGIBB}

\section{TP-4A: UNIT WEIGHT OF SAMPLE}

Project No.: 50161-7-0108

Phase:

Task: 41

Project Name: $\overline{\text { R-Reactor Seepage Basin Perched }}$

Tested By: SC

Date: 07/07/99
Boring No.: RR-03-02

Depth: $10.5-11.5 \mathrm{Ft}$.

Sample ID: Ud

Reviewed By: HEJ

Date: $07 / 18 / 99$

\begin{tabular}{|c|c|c|c|c|c|c|}
\hline \multicolumn{2}{|c|}{$\begin{array}{l}\text { Total Sample } \\
\text { Height, inches }\end{array}$} & \multicolumn{2}{|c|}{$\begin{array}{c}\text { Inside Diameter } \\
\text { of Cut Tube, inches }\end{array}$} & \multicolumn{3}{|c|}{ Moisture Content } \\
\hline 1 & 12.07 & \multirow{3}{*}{$\begin{array}{r}\text { Top } \\
\text { Bottom }\end{array}$} & \multirow[b]{2}{*}{1.403} & Tare No. & $\mathrm{R}-42$ & \multirow[b]{2}{*}{ grams } \\
\hline 2 & 11.94 & & & Tare Weight & 16.61 & \\
\hline 3 & 11.95 & & 1.401 & Wet Weight + Tare & 191.35 & grams \\
\hline Average & 11.99 & Average & 1.402 & Dry Weight + Tare & 168.07 & grams \\
\hline
\end{tabular}

\begin{tabular}{|lcc|}
\hline Total Weight of Soil + Tube Section & 634.70 & grams \\
\cline { 2 - 3 } Weight of Clean, Dry Tube Section & 62.76 & grams \\
\cline { 2 - 3 } Wet Weight of Soil & 1.26 & lbs \\
Volume of Sample & 0.011 & $\mathrm{ft}^{3}$ \\
\hline
\end{tabular}

\section{RESULT SUMMARY}

\begin{tabular}{|l|}
\hline \\
$\begin{array}{l}\text { Moisture Content } \\
\text { Wet Density } \\
\text { Dry Density } \\
\text { Specific Gravity }\end{array}$ \\
$\begin{array}{l}\text { Porosity } \\
\text { Pef }\end{array}$ \\
\cline { 2 - 2 } \\
\hline
\end{tabular}




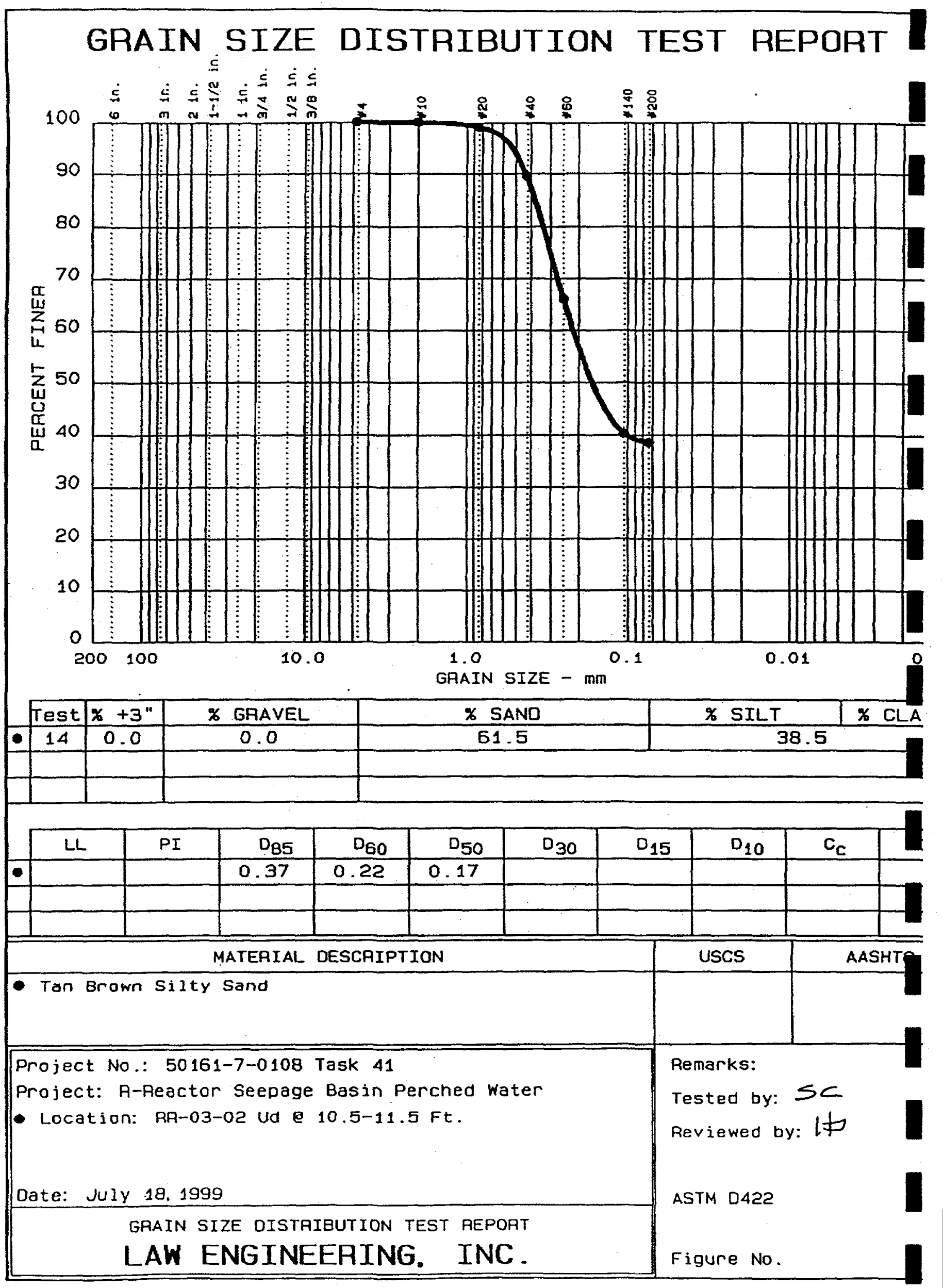




\section{LAWGIBB}

\section{TP-4A: UNIT WEIGHT OF SAMPLE}

Project No.: 50161-7-0108

Phase:

Task: 41

Project Name: $\overline{\text { R-Reactor Seepage Basin Perched }}$

Tested By: $\mathrm{SC}$

Date: $07 / 07 / 99$
Boring No.: RR-03-03

Depth: 14-15 Ft.

Sample ID: Ud

Reviewed By: HEJ

Date: 07/18/99

\begin{tabular}{|c|c|c|c|c|c|c|}
\hline \multicolumn{2}{|c|}{$\begin{array}{l}\text { Total Sample } \\
\text { Height, inches }\end{array}$} & \multicolumn{2}{|c|}{$\begin{array}{l}\text { Inside Diameter } \\
\text { of Cut Tube, inches }\end{array}$} & \multicolumn{3}{|c|}{ Moisture Content } \\
\hline 1 & 12 & & & Tare No. & $\mathrm{C}-27$ & \\
\hline 2 & 12.01 & Top. & 1.405 & Tare Weight & 16.08 & grams \\
\hline 3 & 12.01 & Bottom & 1.405 & Wet Weight + Tare & 180.76 & grams \\
\hline Average & 12.01 & Average & 1.405 & Dry Weight + Tare & 171.05 & grams \\
\hline
\end{tabular}

\begin{tabular}{|lcl|}
\hline Total Weight of Soil + Tube Section & 600.50 & grams \\
\cline { 2 - 2 } Weight of Clean, Dry Tube Section & 63.31 & grams \\
\cline { 2 - 3 } Wet Weight of Soil & 1.18 & $\mathrm{ft}^{3}$ \\
\cline { 2 - 3 } & & 0.011 \\
\hline
\end{tabular}

\section{RESULT SUMMARY}

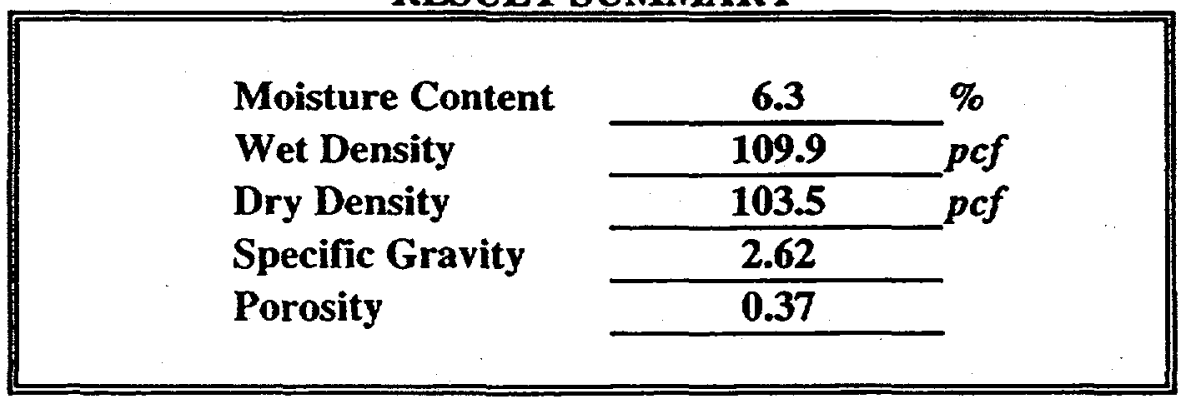




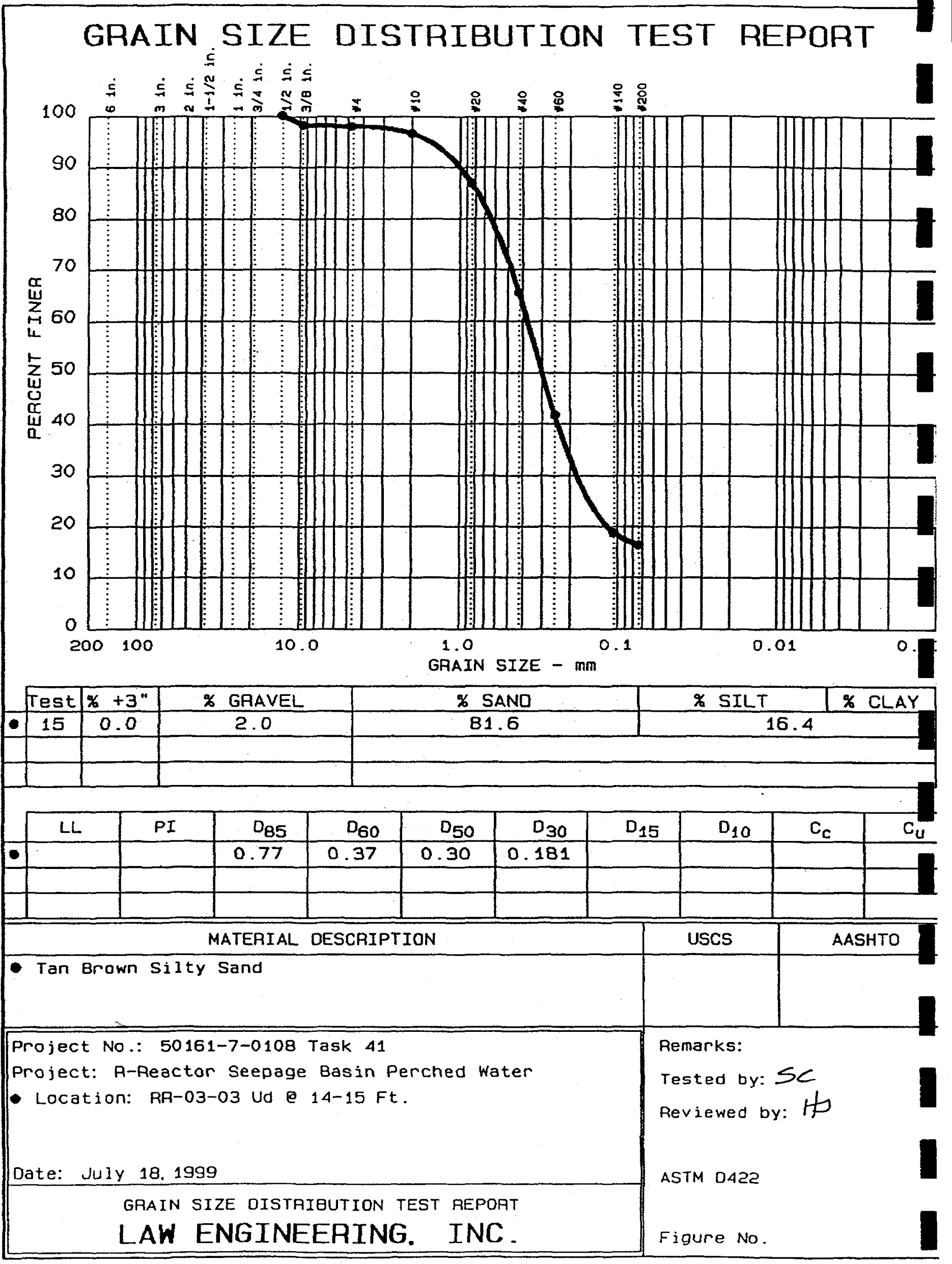




\section{LAWGIBB}

\section{TP-4A: UNIT WEIGHT OF SAMPLE}

Project No.: 50161-7-0108

Phase:

Task: 41

Project Name: R-Reactor Seepage Basin Perched Water

Tested By: SC

Date: $07 / 07 / 99$
Boring No.: RR-03-04

Depth: 18-19 Ft.

Sample ID: Ud

Reviewed By: $\mathrm{HEJ}$

Date: $07 / 18 / 99$

\begin{tabular}{|c|c|c|c|c|c|c|}
\hline \multicolumn{2}{|c|}{$\begin{array}{l}\text { Total Sample } \\
\text { Height, inches }\end{array}$} & \multicolumn{2}{|c|}{$\begin{array}{l}\text { Inside Diameter } \\
\text { of Cut Tube, inches }\end{array}$} & \multicolumn{3}{|c|}{ Moisture Content } \\
\hline 1 & 11.98 & \multirow{3}{*}{$\begin{array}{r}\text { Top } \\
\text { Bottom }\end{array}$} & \multirow[b]{2}{*}{1.395} & Tare No. & $R-40$ & \multirow{3}{*}{$\begin{array}{l}\text { grams } \\
\text { grams }\end{array}$} \\
\hline 2 & 12 & & & Tare Weight & 16.33 & \\
\hline 3 & 12 & & 1.396 & Wet Weight + Tare & 208.16 & \\
\hline Average & 11.99 & Average & 1.396 & $\begin{array}{c}\text { Dry Weight + Tare } \\
\text { Moisture Content }\end{array}$ & $\begin{array}{c}176.24 \\
20.0 \\
\end{array}$ & $\begin{array}{l}\text { grams } \\
\%\end{array}$ \\
\hline
\end{tabular}

\begin{tabular}{|lll|}
\hline Total Weight of Soil + Tube Section & 617.20 & grams \\
\cline { 2 - 3 } & 69.10 & grams \\
\cline { 2 - 3 } & 1.21 & $\mathrm{lbs}$ \\
Wet Weight of Soil & 0.011 & $\mathrm{ft}^{3}$ \\
\hline
\end{tabular}

\section{RESULT SUMMARY}

\begin{tabular}{|l|}
\hline \multicolumn{1}{|c|}{ Moisture Content } \\
Wet Density \\
$\begin{array}{l}\text { Dry Density } \\
\text { Specific Gravity } \\
\text { Porosity }\end{array}$ \\
\cline { 2 - 2 } \\
\cline { 2 - 2 } \\
\hline
\end{tabular}




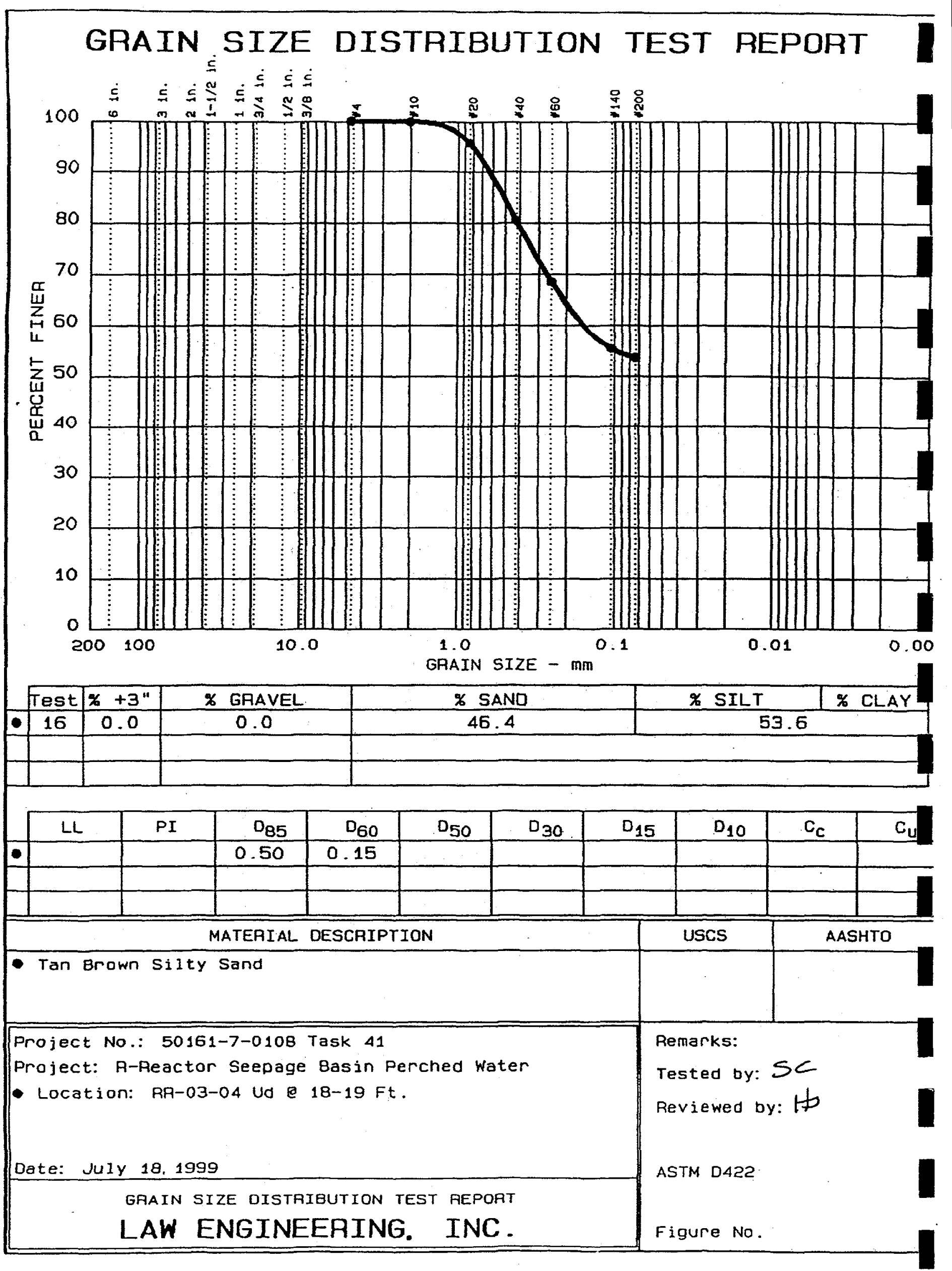


TSRL-TR-9G- $\infty 330$

\section{LAWGIBB}

\section{TP-4A: UNIT WEIGHT OF SAMPLE}

Project No.: 50161-7-0108

Phase:

Task: 41

Project Name: R-Reactor Seepage Basin Perched Water

Tested By: SC

Date: 07/07/99
Boring.No.: RR-03-05

Depth: 20.5-21.5 Ft.

Sample ID: Ud

Reviewed By: HEJ

Date: 07/18/99

\begin{tabular}{|c|c|c|c|c|c|c|}
\hline \multicolumn{2}{|c|}{$\begin{array}{l}\text { Total Sample } \\
\text { Height, inches }\end{array}$} & \multicolumn{2}{|c|}{$\begin{array}{c}\text { Inside Diameter } \\
\text { of Cut Tube, inches }\end{array}$} & \multicolumn{3}{|c|}{ Moisture Content } \\
\hline 1 & 12.12 & \multirow{3}{*}{$\begin{array}{r}\text { Top } \\
\text { Bottom }\end{array}$} & \multirow[b]{2}{*}{1.399} & Tare No. & C-39 & \multirow[b]{2}{*}{ grams } \\
\hline 2 & 12.06 & & & Tare Weight & 16.30 & \\
\hline 3 & 12.2 & & 1.399 & Wet Weight + Tare & 216.87 & grams \\
\hline Average & 12.13 & Average & 1.399 & Dry Weight + Tare & 180.70 & grams \\
\hline
\end{tabular}

\begin{tabular}{|lll|}
\hline Total Weight of Soil + Tube Section & 623.30 & grams \\
\cline { 2 - 3 } Weight of Clean, Dry Tube Section & 69.94 & grams \\
\cline { 2 - 3 } Wet Weight of Soil & 1.22 & lbs \\
\cline { 2 - 3 } & & $\mathrm{ft}^{3}$ \\
\hline
\end{tabular}

\section{RESULT SUMMARY}

\begin{tabular}{|l|}
\hline \\
Moisture Content \\
Wet Density
\end{tabular}




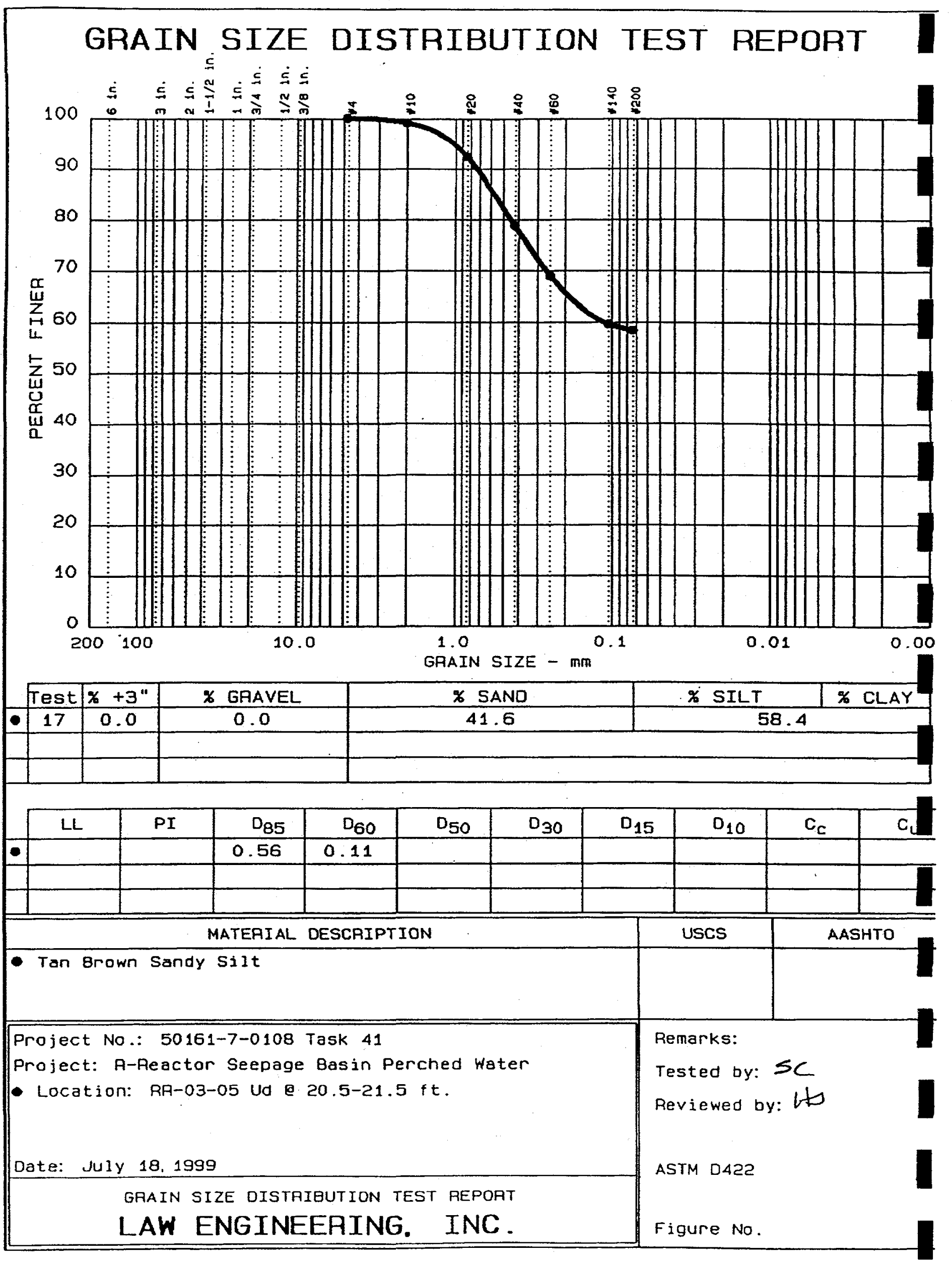


WPRL $-T R-99-00330$

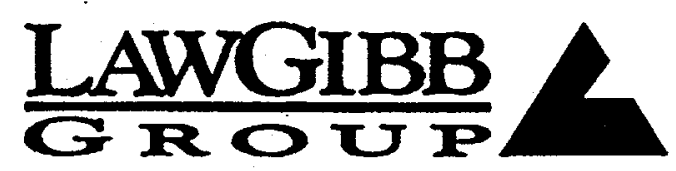

\section{TP-4A: UNIT WEIGHT OF SAMPLE}

Project No.: 50161-7-0108

Phase:

Task: 41

Project Name: R-Reactor Seepage Basin Perched Water

Tested By: SC

Date: $07 / 07 / 99$
Boring No.: RR-03-06

Depth: 22.5-23.5 Ft.

Sample ID: Ud

Reviewed By: HEJ

Date: $07 / 18 / 99$

\begin{tabular}{|c|c|c|c|c|c|c|}
\hline \multicolumn{2}{|c|}{$\begin{array}{l}\text { Total Sample } \\
\text { Height, inches } \\
\end{array}$} & \multicolumn{2}{|c|}{$\begin{array}{c}\text { Inside Diameter } \\
\text { of Cut Tube, inches }\end{array}$} & \multicolumn{3}{|c|}{ Moisture Content } \\
\hline 1 & 11.7 & \multirow{3}{*}{$\begin{array}{l}\text { Top } \\
\text { Bottom }\end{array}$} & \multirow[b]{2}{*}{1.396} & \multirow{5}{*}{$\begin{array}{r}\text { Tare No. } \\
\text { Tare Weight } \\
\text { Wet Weight + Tare } \\
\text { Dry Weight + Tare } \\
\text { Moisture Content }\end{array}$} & A-11 & \multirow{3}{*}{$\begin{array}{l}\text { grams } \\
\text { grams }\end{array}$} \\
\hline 2 & 11.72 & & & & 14.67 & \\
\hline 3 & 11.77 & & 1.395 & & 212.71 & \\
\hline \multirow[t]{2}{*}{ Average } & 11.73 & \multirow[t]{2}{*}{ Average } & 1.396 & & 176.08 & grams \\
\hline & & & & & 22.7 & $\%$ \\
\hline
\end{tabular}

\begin{tabular}{|lll|}
\hline Total Weight of Soil + Tube Section & 624.50 & grams \\
\cline { 2 - 3 } Weight of Clean, Dry Tube Section & 68.09 & grams \\
\cline { 2 - 3 } Wet Weight of Soil & 1.23 & lbs \\
\cline { 2 - 3 } & & $\mathrm{ft}^{3}$ \\
\hline
\end{tabular}

RESULT SUMMARY

\begin{tabular}{|l|l|}
\hline & Moisture Content \\
Wet Density & 22.7 \\
Dry Density & pcf \\
Specific Gravity & pcf \\
Porosity & $\frac{96.3}{2.68}$ \\
\hline
\end{tabular}




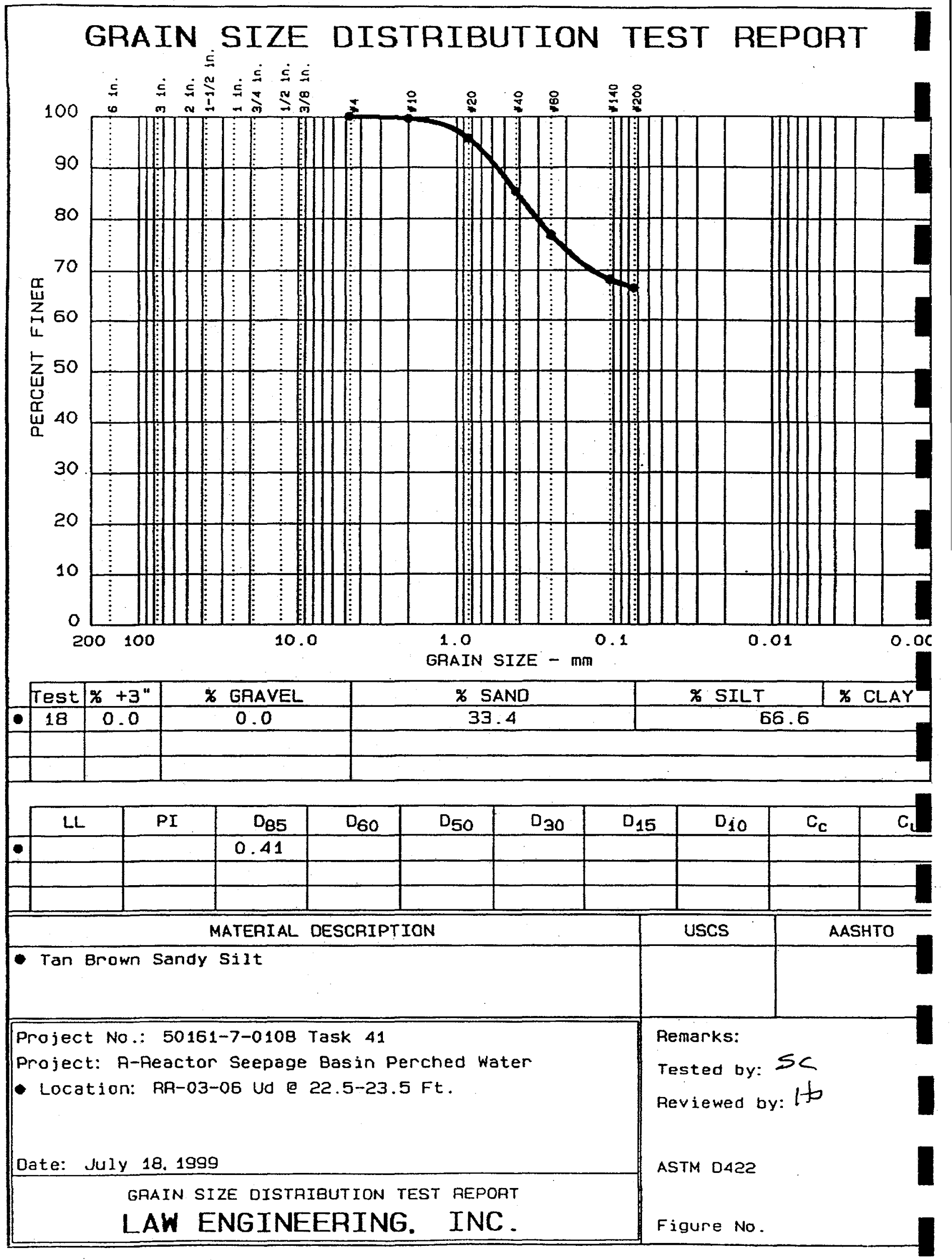




\section{LAWGIBB}

\section{TP-4A: UNIT WEIGHT OF SAMPLE}

Project No.: 50161-7-0108

Phase:

Task: 41

Project Name: $\overline{\text { R-Reactor Seepage Basin Perched }}$

Tested By: SC

Date: 07/07/99
Boring No.: RR-03-07

Depth: 26-27 Ft.

Sample ID: Ud

Reviewed By: $\mathrm{HEJ}$

Date: $07 / 18 / 99$

\begin{tabular}{|c|c|c|c|c|c|c|}
\hline \multicolumn{2}{|c|}{$\begin{array}{l}\text { Total Sample } \\
\text { Height, inches }\end{array}$} & \multicolumn{2}{|c|}{$\begin{array}{c}\text { Inside Diameter } \\
\text { of Cut Tube, inches }\end{array}$} & \multicolumn{3}{|c|}{ Moisture Content } \\
\hline$\overline{11}$ & 11.87 & \multirow{3}{*}{$\begin{array}{r}\text { Top } \\
\text { ottom }\end{array}$} & \multirow[b]{2}{*}{1.396} & Tare No. & $\mathrm{V}-9$ & \multirow{3}{*}{$\begin{array}{l}\text { grams } \\
\text { grams }\end{array}$} \\
\hline 2 & 11.89 & & & Tare Weight & 15.39 & \\
\hline 3 & 11.85 & & 1.397 & Wet Weight + Tare & 217.33 & \\
\hline Average & 11.87 & Average & 1.397 & $\begin{array}{l}\text { Dry Weight + Tare } \\
\text { Mojsture Content }\end{array}$ & $\frac{185.63}{18.6}$ & $\begin{array}{l}\text { grams } \\
\%\end{array}$ \\
\hline
\end{tabular}

\section{RESULT SUMMARY}

\begin{tabular}{|l|}
\hline Moisture Content \\
Wet Density \\
$\begin{array}{l}\text { Dry Density } \\
\text { Specific Gravity } \\
\text { Porosity }\end{array}$ \\
\cline { 2 - 2 } \\
\cline { 2 - 2 } \\
\cline { 2 - 2 }
\end{tabular}




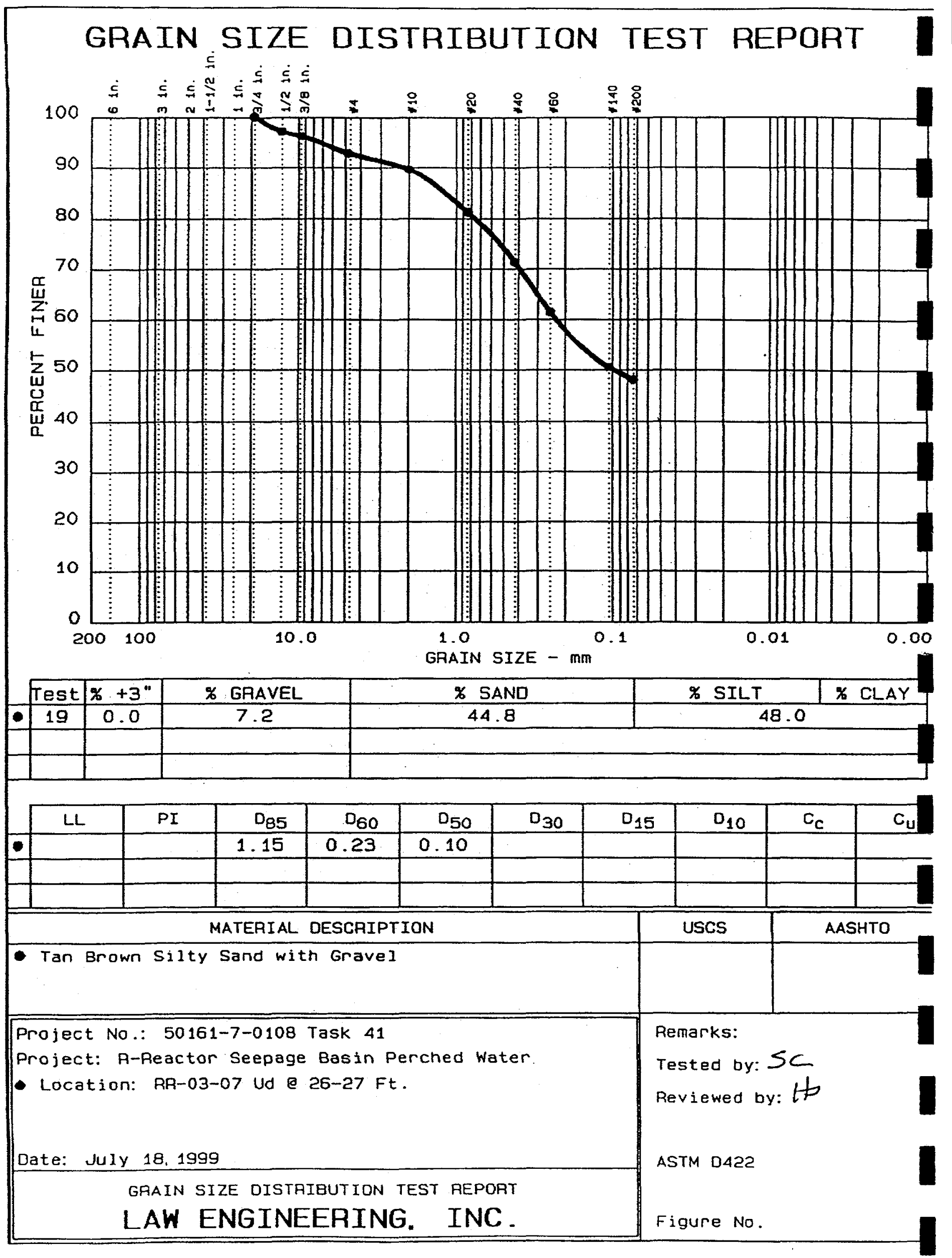




\section{LAWGIBB}

\section{TP-4A: UNIT WEIGHT OF SAMPLE}

Project No.: 50161-7-0108

Phase:

Task: 41

Project Name: $\overline{\text { R-Reactor Seepage Basin Perched }}$

Tested By: $\mathrm{SC}$

Date: $07 / 07 / 99$
Boring No.: RR-03-08

Depth: 57.5-58.5 Ft.

Sample ID: Ud

Reviewed By: HEJ

Date: $07 / 18 / 99$

\begin{tabular}{|c|c|c|c|c|c|c|}
\hline \multicolumn{2}{|c|}{$\begin{array}{l}\text { Total Sample } \\
\text { Height, inches. }\end{array}$} & \multicolumn{2}{|c|}{$\begin{array}{l}\text { Inside Diameter } \\
\text { of Cut Tube, inches }\end{array}$} & \multicolumn{3}{|c|}{ Moisture Content } \\
\hline 1 & 11.97 & \multirow{3}{*}{$\begin{array}{r}\text { Top } \\
\text { Bottom }\end{array}$} & \multirow[b]{2}{*}{1.399} & Tare No. & $R-48$ & \multirow{3}{*}{$\begin{array}{l}\text { grams } \\
\text { grams }\end{array}$} \\
\hline 2 & 12.07 & & & Tare Weight & 16.91 & \\
\hline 3 & 12.07 & & 1.399 & Wet Weight + Tare & 182.26 & \\
\hline Average & 12.04 & Average & 1.399 & Dry Weight + Tare & 154.25 & grams \\
\hline
\end{tabular}

\begin{tabular}{|lll|}
\hline Total Weight of Soil + Tube Section & 634.05 & grams \\
\cline { 2 - 3 } Weight of Clean, Dry Tube Section & 69.60 & grams \\
\cline { 2 - 3 } Wet Weight of Soil & 1.24 & $\mathrm{ft}^{3}$ \\
\cline { 2 - 3 } & & \\
\hline
\end{tabular}

RESULT SUMMARY

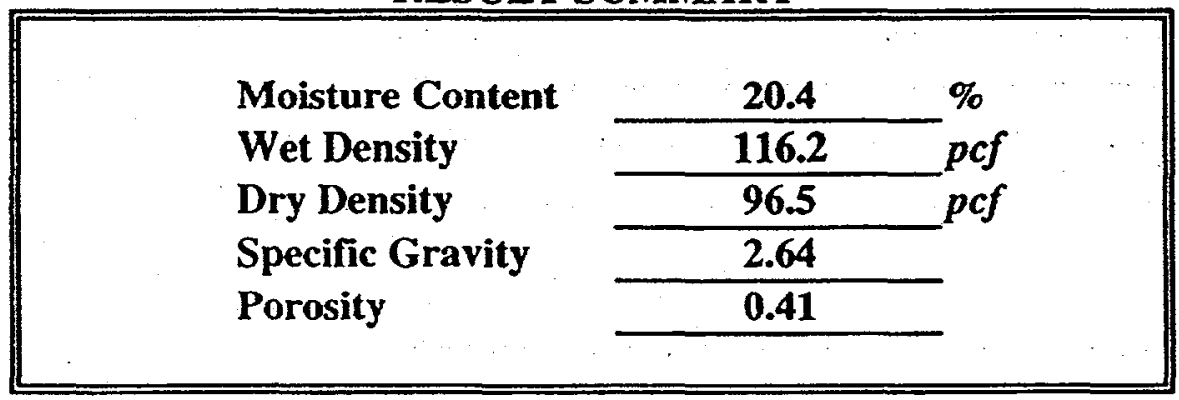




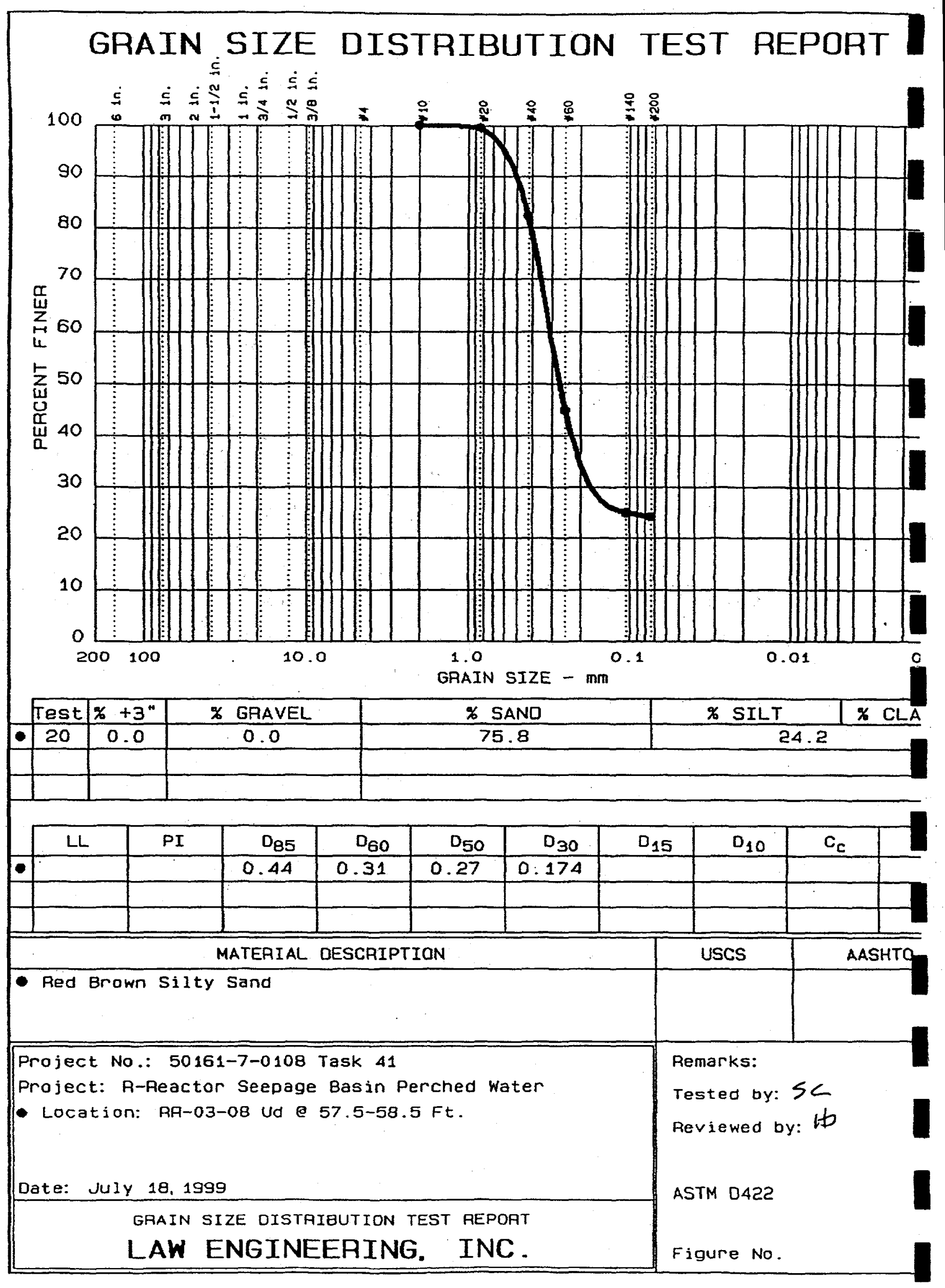




\section{LAWGIBB}

\section{TP-4A: UNIT WEIGHT OF SAMPLE}

Project No.: 50161-7-0108

Phase:

Task: 41

Project Name: R-Reactor Seepage Basin Perched

Tested By: SC

Date: $07 / 07 / 99$
Boring No.: RR-03-09

Depth: 83.5-84.5 Ft.

Sample ID: Ud

Reviewed By: HEJ

Date: $07 / 18 / 99$

\begin{tabular}{|c|c|c|c|c|c|c|}
\hline \multicolumn{2}{|c|}{$\begin{array}{l}\text { Total Sample } \\
\text { Height, inches }\end{array}$} & \multicolumn{2}{|c|}{$\begin{array}{c}\text { Inside Diameter } \\
\text { of Cut Tube, inches }\end{array}$} & \multicolumn{3}{|c|}{ Moisture Content } \\
\hline 1 & 12.2 & \multirow{3}{*}{$\begin{array}{r}\text { Top } \\
\text { Bottom }\end{array}$} & \multirow[b]{2}{*}{1.394} & Tare No. & $\mathrm{R}-4$ & \multirow{3}{*}{$\begin{array}{l}\text { grams } \\
\text { grams }\end{array}$} \\
\hline 2 & 12.2 & & & Tare Weight & 16.41 & \\
\hline 3 & 12.22 & & 1.393 & Wet Weight + Tare & 244.57 & \\
\hline Average & 12.21 & Average & 1.394 & $\begin{array}{l}\text { Dry Weight + Tare } \\
\text { Moisture Content }\end{array}$ & $\frac{192.01}{29.9}$ & $\begin{array}{l}\text { grams } \\
\%\end{array}$ \\
\hline
\end{tabular}

RESULT SUMMARY

\begin{tabular}{|l|}
\hline Moisture Content \\
$\begin{array}{l}\text { Wet Density } \\
\text { Dry Density } \\
\text { Specific Gravity } \\
\text { Porosity }\end{array}$ \\
\cline { 2 - 2 } \\
\cline { 2 - 2 } \\
\end{tabular}




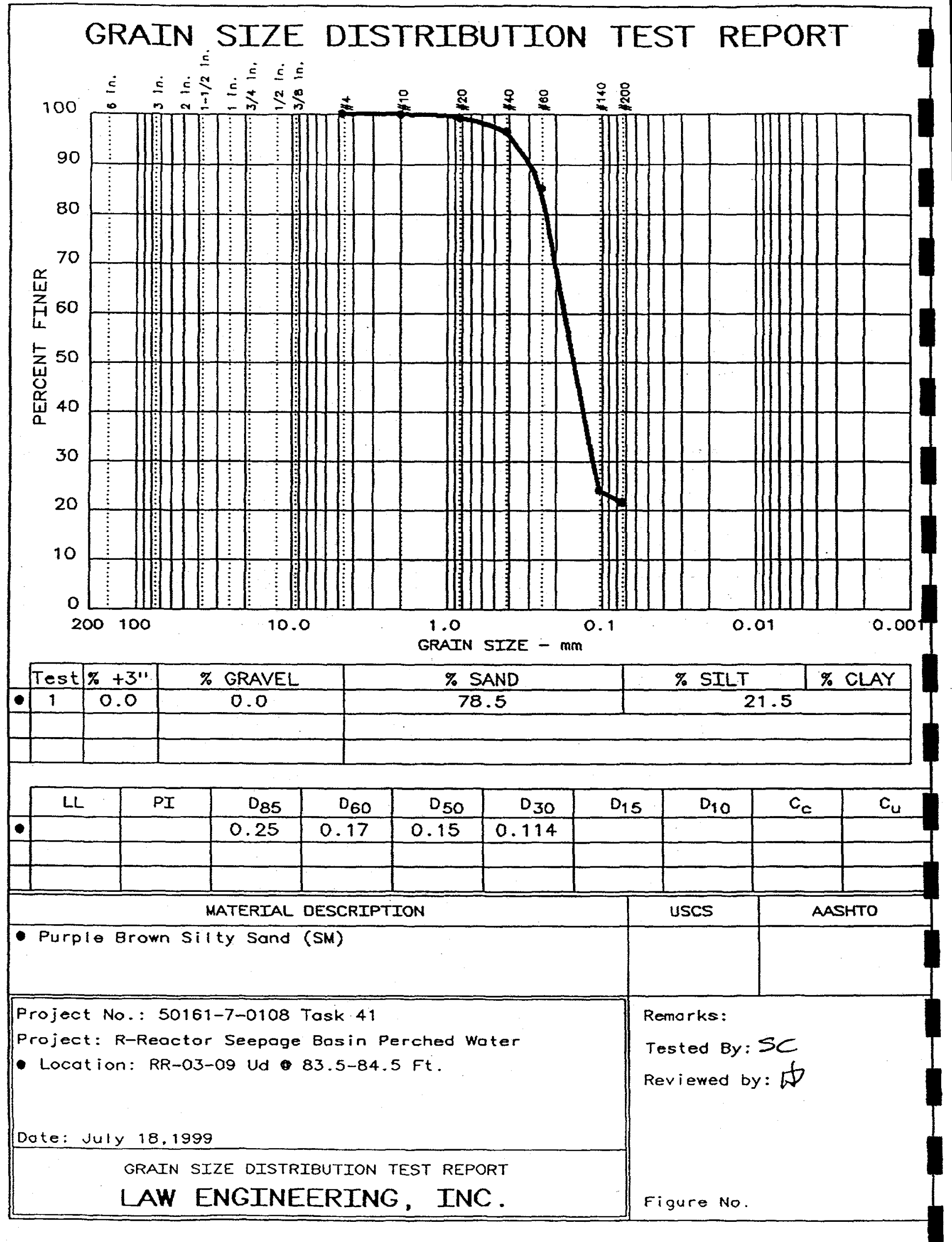




\section{LAWGIBB}

\section{TP-4A: UNIT WEIGHT OF SAMPLE}

Project No.: 50161-7-0108

Phase:

Task: 41

Project Name: R-Reactor Seepage Basin Perched

Tested By: SC

Date: 07/07/99
Boring No.: RR-03-10

Depth: 100.5-101.5 Ft.

Sample ID: Ud

Reviewed By: HEJ

Date: $07 / 18 / 99$

\begin{tabular}{|c|c|c|c|c|c|c|}
\hline \multicolumn{2}{|c|}{$\begin{array}{l}\text { Total Sample } \\
\text { Height, inches }\end{array}$} & \multicolumn{2}{|c|}{$\begin{array}{l}\text { Inside Diameter } \\
\text { of Cut Tube, inches }\end{array}$} & \multicolumn{3}{|c|}{ Moisture Content } \\
\hline 1 & 12.04 & \multirow{3}{*}{$\begin{array}{r}\text { Top } \\
\text { Bottom }\end{array}$} & \multirow[b]{2}{*}{1.398} & Tare No. & V-80 & \multirow[b]{2}{*}{ grams } \\
\hline 2 & 12.04 & & & Tare Weight & 16.91 & \\
\hline 3 & 12.05 & & 1.395 & Wet Weight + Tare & 243.47 & grams \\
\hline Average & 12.04 & Average & 1.397 & Dry Weight + Tare & 196.12 & grams \\
\hline
\end{tabular}

\begin{tabular}{|c|c|c|}
\hline Total Weight of Soil + Tube Section & $\overline{637.30}$ & grams \\
\hline Weight of Clean, Dry Tube Section & 68.47 & grams \\
\hline Wet Weight of Soil & 1.25 & lbs \\
\hline Volume of Sample & 0.011 & ft \\
\hline
\end{tabular}

RESULT SUMMARY

\begin{tabular}{|l|}
\hline Moisture Content \\
Wet Density \\
$\begin{array}{l}\text { Dry Density } \\
\text { Specific Gravity } \\
\text { Porosity }\end{array}$ \\
\cline { 2 - 2 } \\
\cline { 2 - 2 }
\end{tabular}




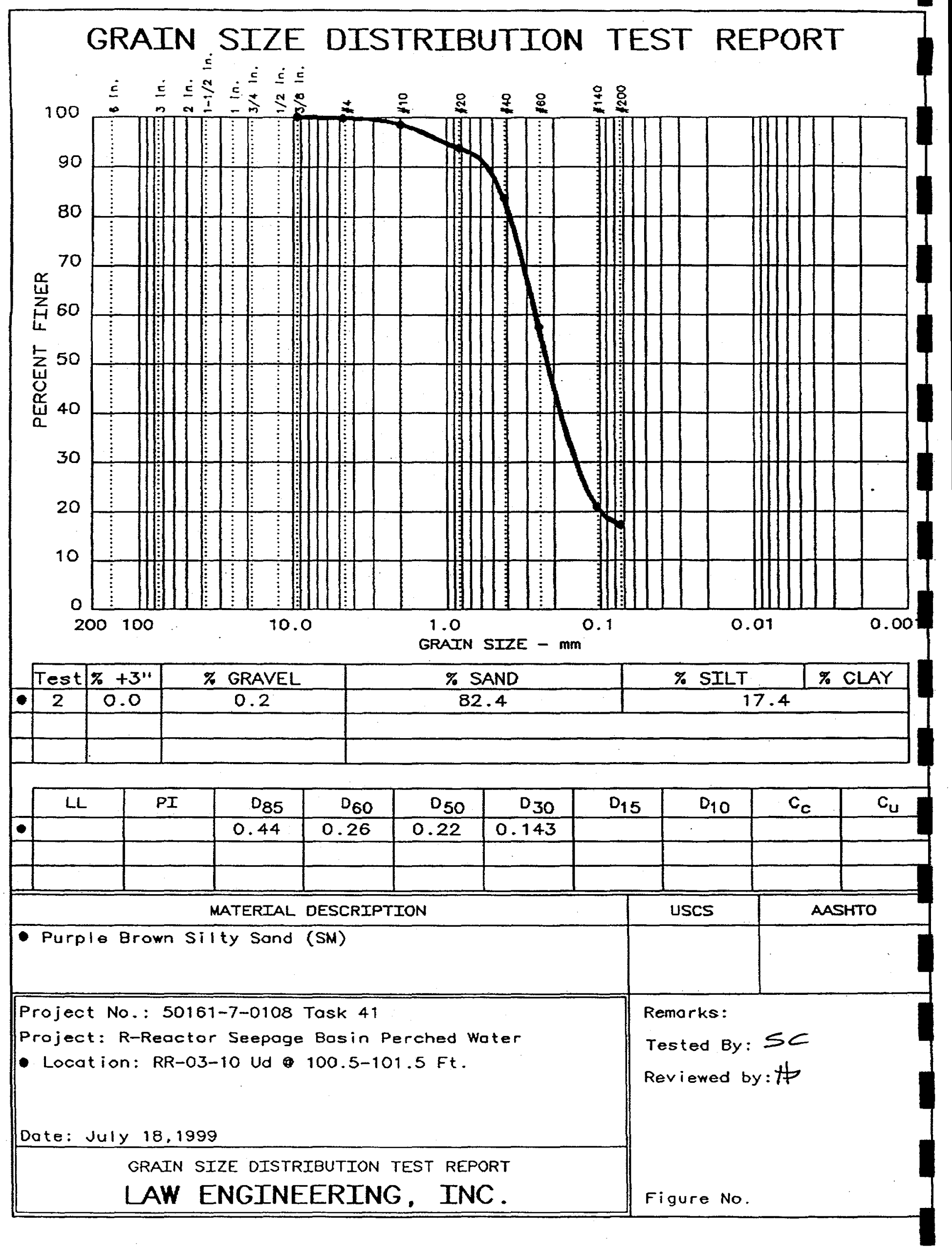


Appendix D - Water Level Data and Hydrographs 


\section{This page intentionally left blank}


Table D-1 R Area Water Level Measurements

\begin{tabular}{|c|c|c|c|c|c|c|c|c|c|c|c|c|c|c|c|}
\hline ell ID & asting & Northing & Grd. El. & Bot-scr & Top-scr & Mar-98 & Aug-98 & Nov-98 & $\operatorname{Jan}-99$ & Feb-99 & Mar-99 & Apr-99 & May-99 & Jun-99 & Jul-99 \\
\hline$P 20 C$ & 814.00 & 3067.70 & 287.80 & 138.00 & 148.00 & 241.8 & 240.8 & NR & 235.98 & 236.09 & 235.85 & 235.58 & 235.11 & 234.77 & 5.04 \\
\hline 200 & 84.50 & .20 & 7.70 & 25.40 & 4.40 & 4. & 272 & 68.8 & 151 & 6451 & & 66 & 6336 & & \\
\hline AC 1 & & & 32.60 & & 7.30 & & 272.5 & 5 & & & 73.4 & & & סקט & \\
\hline AC 2 & 5.50 & 3.30 & 78.70 & & 3.40 & 3.85 & 270.9 & 0.4 & 71.2 & 73.55 & 72.6 & & & & 73. \\
\hline$A C 3$ & 667.50 & 015.30 & 277.60 & 42. & 272.30 & 74.25 & 270.9 & 70.1 & 0 & 272.78 & 272.35 & & & & 70 \\
\hline AC 4 & 588.80 & 984.00 & 277.50 & 38 & 200 & & 271 & & & 7 & 272 & 71.38 & $70 \quad 2$ & $\mathrm{~N}$ & 72.6 \\
\hline D & 00 & 00 & & & & & $-2 x_{1}$ & & & & 201.10 & & 200.0 & & \\
\hline$B P 2 D$ & .00 & .00 & 303.20 & & 3.00 & & 267.25 & & & & 259.95 & & 258.75 & & 57 \\
\hline$B P$ 3D & .00 & 828.00 & 307.50 & & & & 269.8 & & & & & & & & 260.7 \\
\hline$C P 1 A$ & .30 & & & & & & 221 & & & & & & 243 & & 42.9 \\
\hline $\mathrm{CP} 1 \mathrm{D}$ & & & & & & & & & & 35 & & 78 & & & 80.4 \\
\hline DB 1D & & & & & & & & & & & 286.2 & 5 & & & \\
\hline B $2 D$ & & & & & & & & & & & & & & & .r \\
\hline 30 & & & & & & & & & & & 282.45 & $28:$ & & & 84.8 \\
\hline toni & & & 296 & & & & & & & & | & & & & \\
\hline & & & & & & & & & & & & & & & \\
\hline & .08 & & 291 & & & & & & & & & & & & 27 \\
\hline DU & 1 & & & & & & & & Nu & & & & & $\mathrm{Nu}$ & AO \\
\hline & 66 & & & & & & & & & & & & & & NR \\
\hline${ }^{\circ} \mathrm{C} 1 \mathrm{CU}$ & & & & & & & & & & & & & & & NR \\
\hline $1 \mathrm{CL}$ & .88 & & & & & & & & & & & & & & $\pi$ \\
\hline & & & & & & & & & & & & & & & \\
\hline $\mathrm{CU}$ & & & & & & & & & & & & & & & \\
\hline LL & & & & & & & & & & & & & & & \\
\hline 3DL & & & & & & & & & & & & & & & \\
\hline & & & & & & & & & & & & & & & \\
\hline OL & & & & & & & & & & & & & & & 0.7 \\
\hline & & & & & & & & & & & & & & & 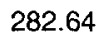 \\
\hline & & & & & & & 272 & & & & & & & & 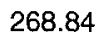 \\
\hline & & & & & & & & & & & & & & & \\
\hline DI & & & & & & & 27 & & & & 27 & & & & \\
\hline $6 \mathrm{DU}$ & & & & & & & & & & & & & & & \\
\hline & & & & & & & & & & & & & & & \\
\hline & & & & & & & & & & & & & & & \\
\hline & & & & & & & & & & & & & & & \\
\hline $3 D U$ & .76 & 582 & & & & & & & & & 280.2 & $c$ & & & 280.4 \\
\hline 9DL & 745 & 579 & & 21 & & & 282.02 & & 27 & & 276.97 & & .42 & & 276. \\
\hline & & & & & & & & & & & & & & & \\
\hline & & & & & & & & & & & 265 & 26 & & & \\
\hline & & & & & & & & & 26 & & $\mathrm{~N}$ & & N & IV & 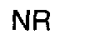 \\
\hline & 75389.30 & 58172.80 & 310.00 & 268.80 & 288 & 291 & 281 & NR & NR & & $\mathrm{N} / \mathrm{r}$ & & ivn & NR & NR \\
\hline & 756 & & 310.00 & 264.60 & & & & NR & NR & NR & NR & NR & NR & NR & \\
\hline & & & & & & & & & & & & & & 280 & \\
\hline
\end{tabular}




\begin{tabular}{|c|c|c|c|c|c|c|c|c|c|c|c|c|c|c|c|}
\hline ell ID & asting & Northing & rd. El. & Bot-scr & Top-scr & Mar-98 & Aug-98 & Nov-98 & Jan-99 & Feb-99 & Mar-99 & Apr-99 & May-9 & Jun- & \\
\hline SC 10 & 5470.00 & 9542.70 & 293.80 & 255.50 & 275.50 & 279.45 & 272.1 & 269.5 & 269.05 & 269.95 & 269.4 & 269 & 268.45 & 267.8 & 8 \\
\hline SC 2 & 378.60 & 3543.00 & 00.20 & 261.90 & 281.90 & 105 & 281.3 & 82.4 & 76.8 & 774 & 277.1 & 6.8 & & 275 & \\
\hline & 4699.70 & 724.70 & 99.90 & 60 & 8.60 & 00 & & 77.1 & 75 & & 75.6 & & & & \\
\hline & 5097.80 & 0.30 & 98.90 & & 8.60 & & 280 & 6.8 & & - & 7.45 & 76.2 & & 3.75 & 8.15 \\
\hline & 86.10 & 17.10 & 02.10 & 67.70 & חד דחס & & & & & & & 79.35 & & & 91.25 \\
\hline & 86.20 & 3200.10 & 5.80 & 263.40 & 283.40 & 295 & 282.8 & 278.2 & 4.85 & 76.6 & 5.9 & 275. & 05 & 1 & 7.4 \\
\hline & 4.00 & 3.10 & $0 /$ & 71.30 & .30 & .25 & 291.2 & 3.1 & 1 & & & 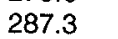 & & & 7.7 \\
\hline & .10 & 80 & & 67.90 & & 25 & & & & & & & $\mathrm{~N}$ & & 2.25 \\
\hline & & 1.60 & & & & & & & & & & 85.65 & & 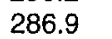 & 38.75 \\
\hline & .60 & 1.40 & & 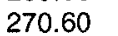 & & & 90 & & & & & & NR & NR & 0.1 \\
\hline & & 0 & & 30 & & & 25 & & & 5 & & & & & 7.9 \\
\hline & 60 & 30 & & 0.10 & & 5 & & & & & & & & & .95 \\
\hline & & & & & & & & & & & & & & & 6.15 \\
\hline & & 0 & & & & US & $<c$ & 82.92 & & & & 84.05 & NR & VR & 36.2 \\
\hline & & 30 & & & & 87.65 & 4.35 & 82.15 & 4 & 02 & 3.18 & 329 & & & 4.08 \\
\hline $1 \mathrm{~A}$ & & 50 & & 4.80 & & 294.35 & 55 & & & & & & & & 7.45 \\
\hline & & 90 & & 0 & & & & & & & & & & & 86.1 \\
\hline & & & & & & 28 & 28 & & & & & & 95 & 278.8 & 30 \\
\hline & & 0 & & & & & 7 & & & 6 & .55 & 75.45 & 275 & NR & $J R$ \\
\hline $3 A$ & 1.20 & 574 & & 8.20 & & 8.15 & & & & & & מרח & & & .75 \\
\hline 7 & 1783.70 & $584 \varepsilon$ & & 266.50 & & 298 & & & & & & & & & 7.18 \\
\hline & 869.40 & 58538.80 & & & & & & 28 & & 75 & ne & 28 & 283.15 & 282.3 & 284.28 \\
\hline & & & & & & 8225 & & & & & & & & (ח) & 吅 \\
\hline 1 & 869.40 & 585 & & 30 & & 286.35 & 28 & & & & & & & NRK & \\
\hline 2 & 628.60 & 5767 & & 224.80 & .30 & 285.6 & 282.75 & 279.9 & & 25 & & NR & & NR & 78.1 \\
\hline & 206.70 & 576 & & & & & & & & & & & & 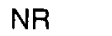 & \\
\hline $4 \mathrm{D}$ & 00 & & & & & & & & & & & .06 & 278.38 & & 79.73 \\
\hline $5 \mathrm{D}$ & & & & & & & & 270.04 & 0.24 & 270.29 & J.34 & .34 & 270.34 & 270.44 & 70.39 \\
\hline $6 \mathrm{D}$ & 75363.00 & 59311.00 & & 255.90 & 276.00 & 278.57 & 273.12 & 262.62 & 269.57 & 269.97 & 269.77 & 269.52 & 268.97 & 268.57 & 9.62 \\
\hline 70 & 74295.00 & 59123.00 & 2.59 & 58.50 & 278.40 & 279.54 & 275.69 & 273.29 & 272.29 & 272.59 & 272.39 & 272.39 & 271.99 & 264.39 & 1.6 \\
\hline
\end{tabular}
*NR $=$ No reading 
APC 1 Well Hydrographs
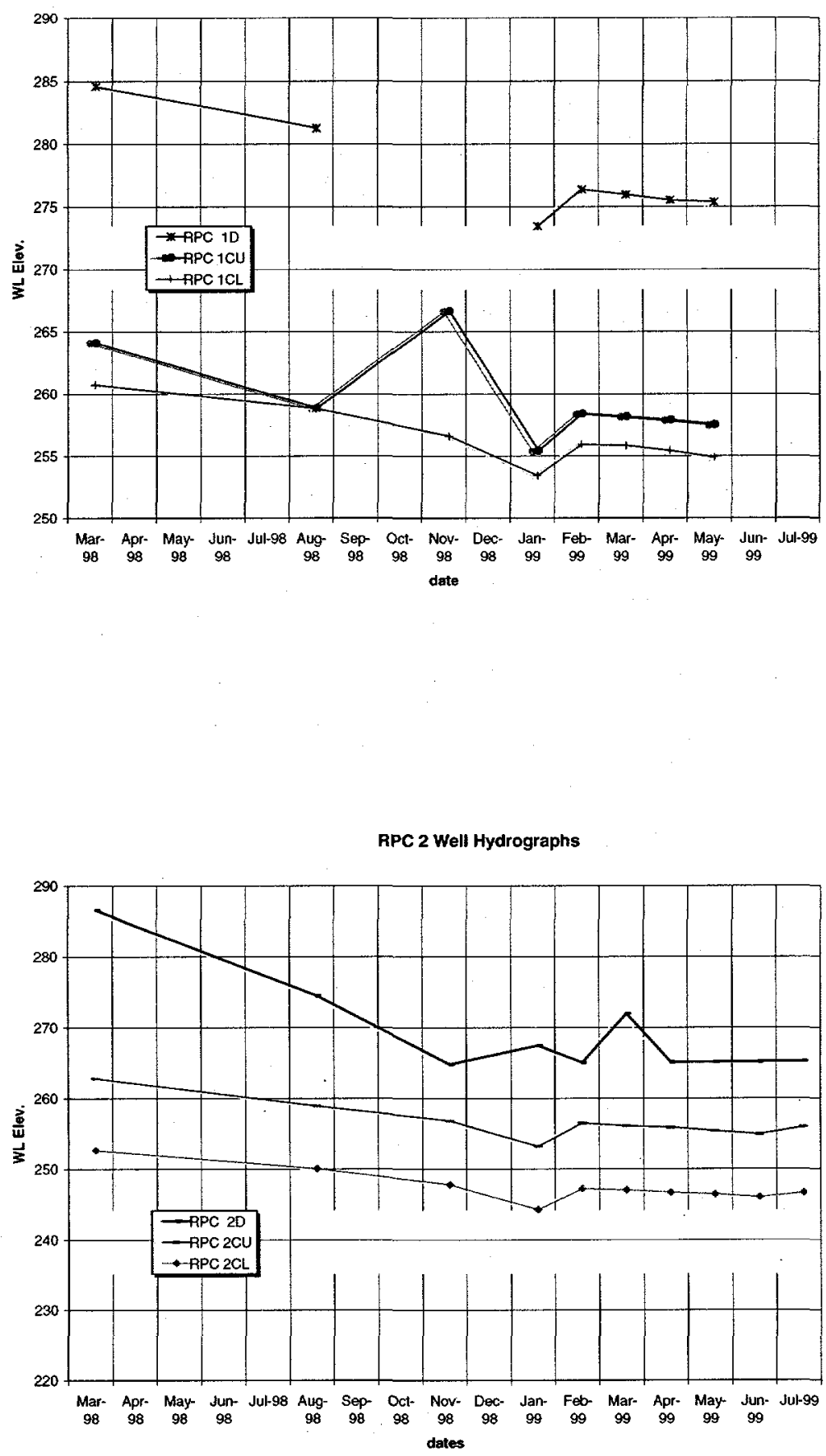
RPC 3 Well Hydrographs

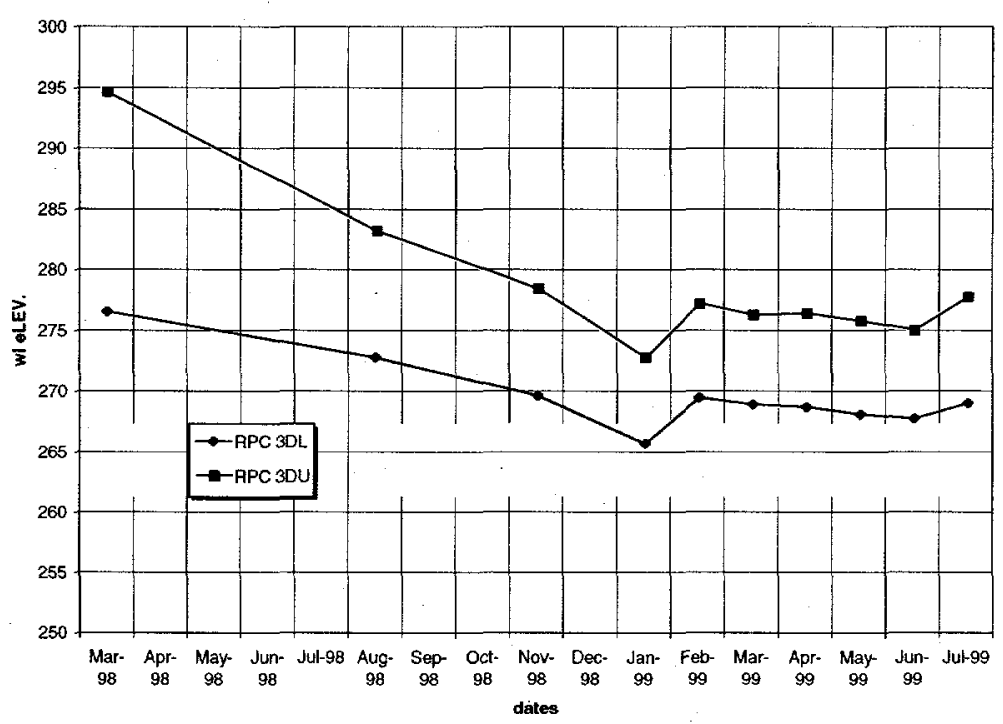

RPC 4 Well Hydrographs

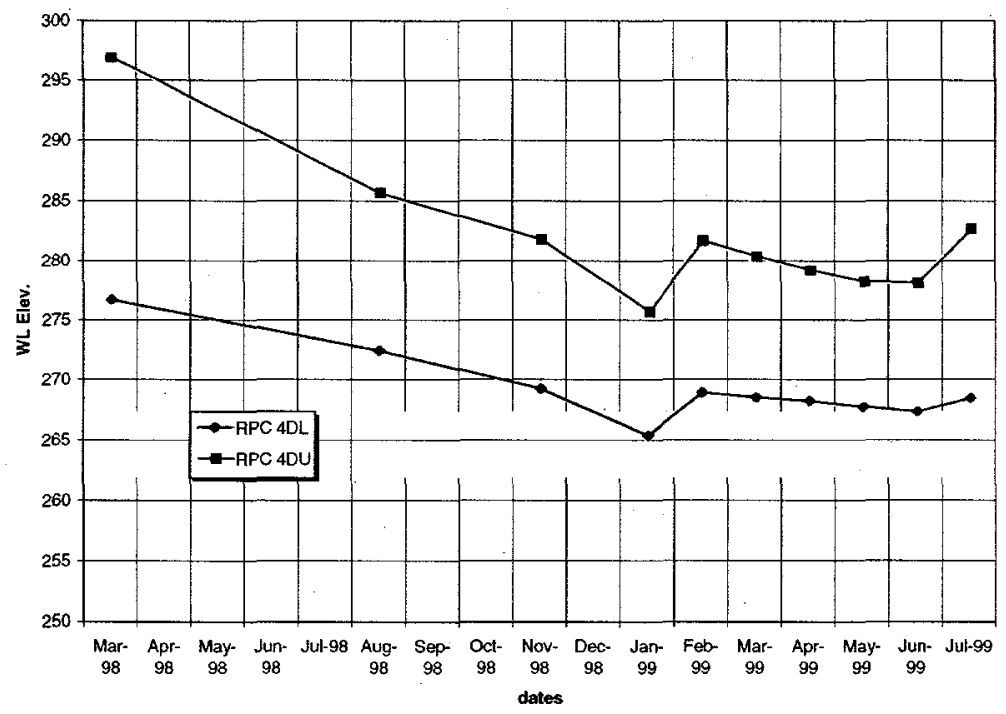



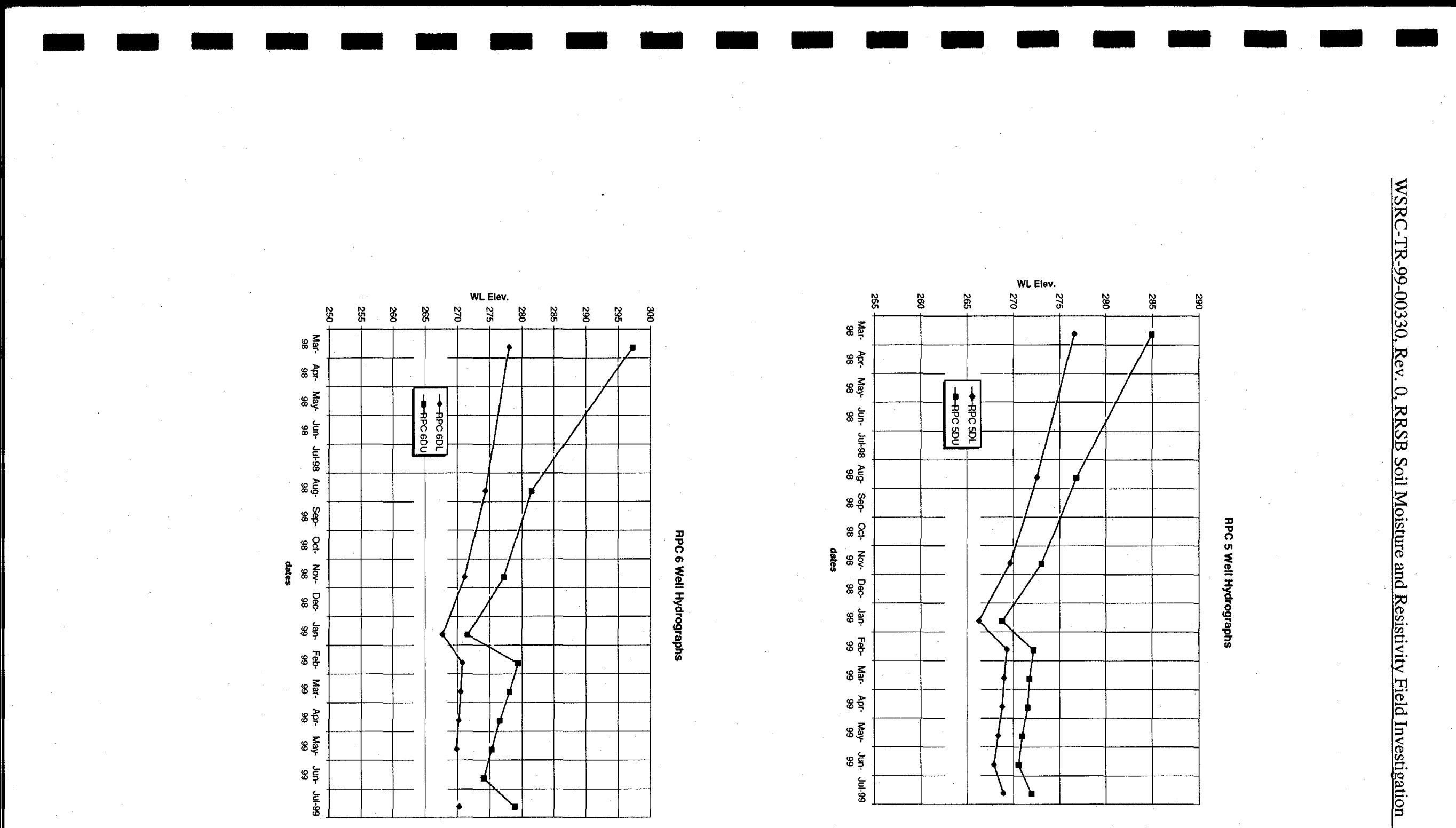

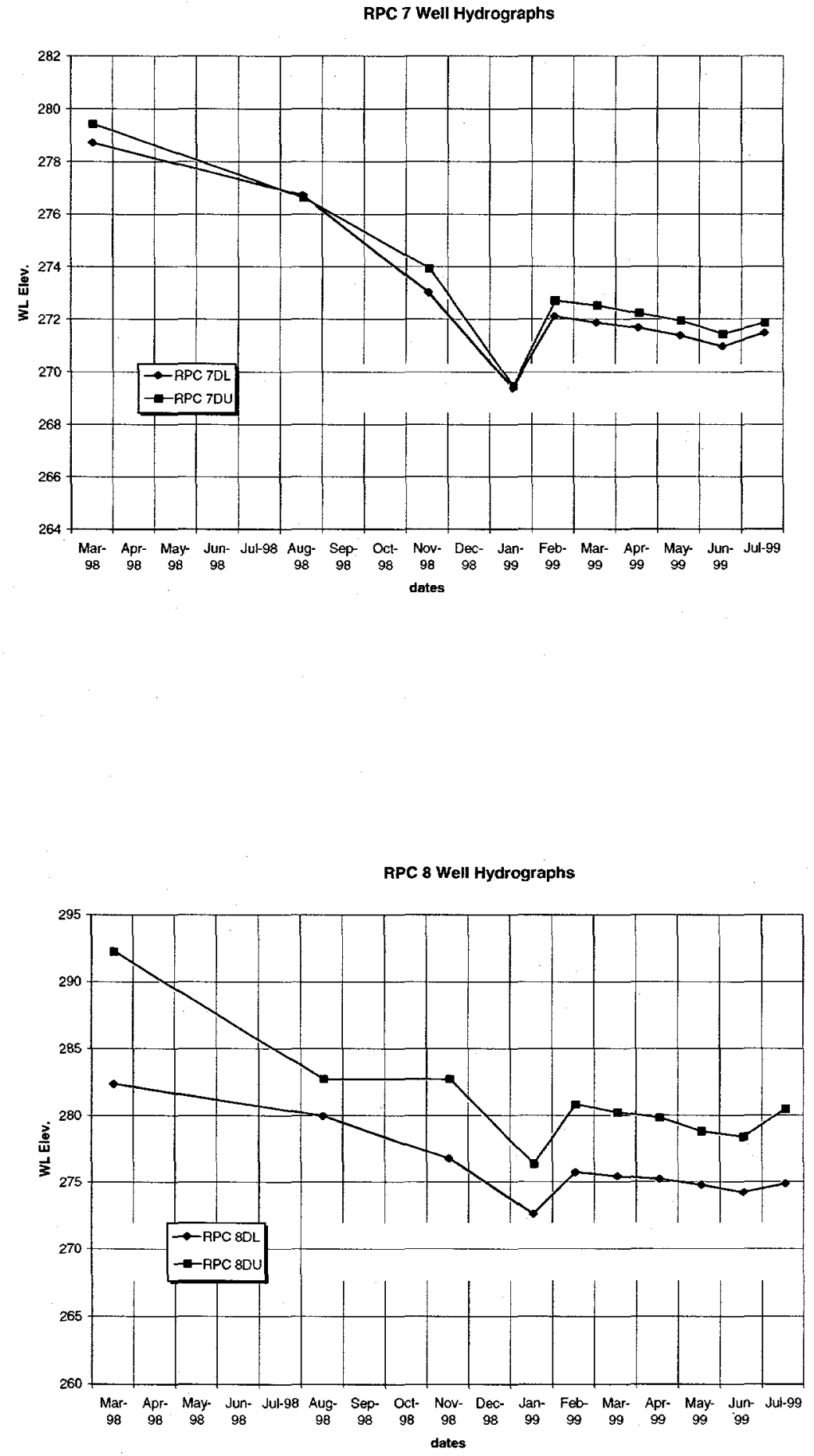

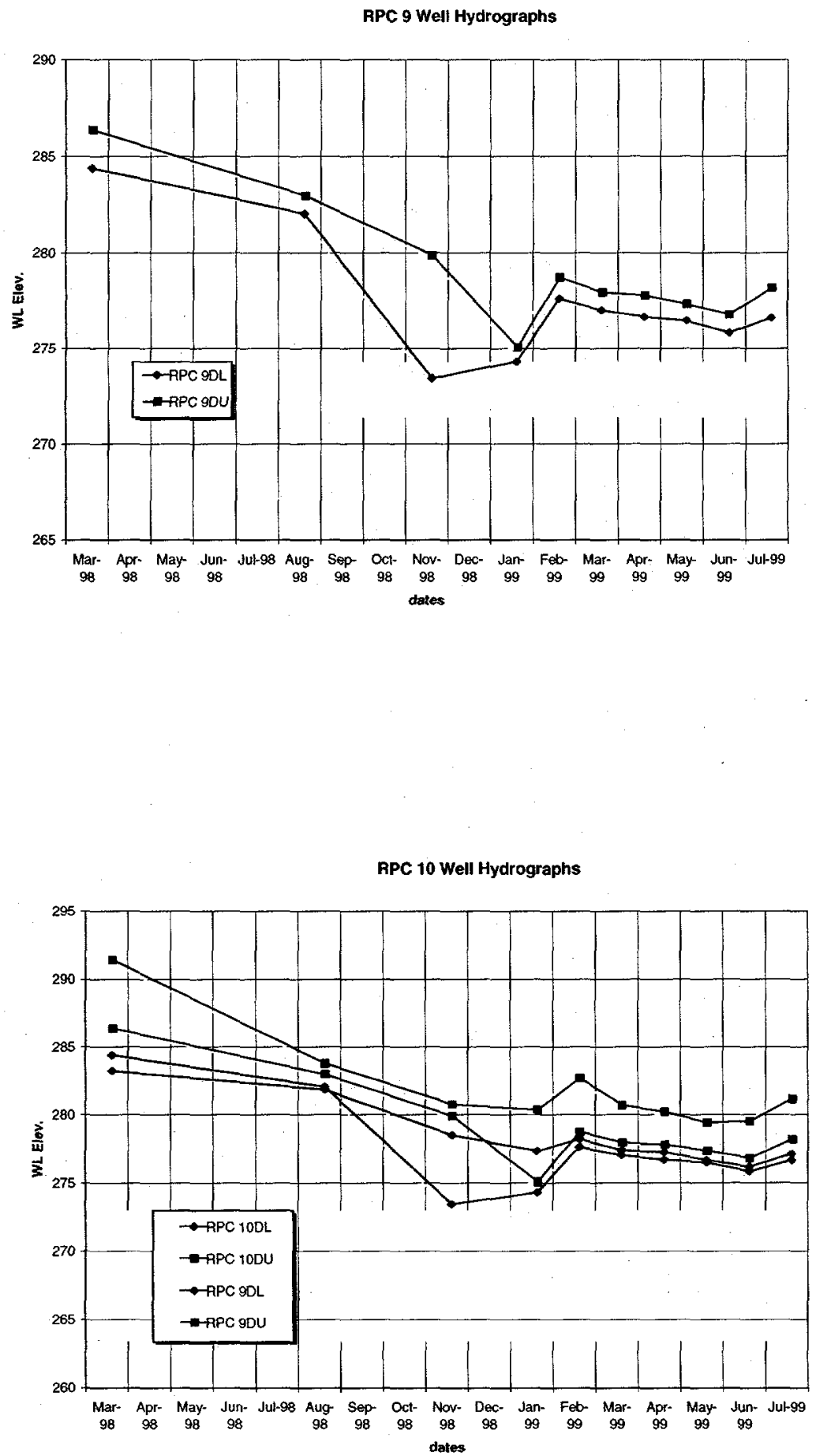


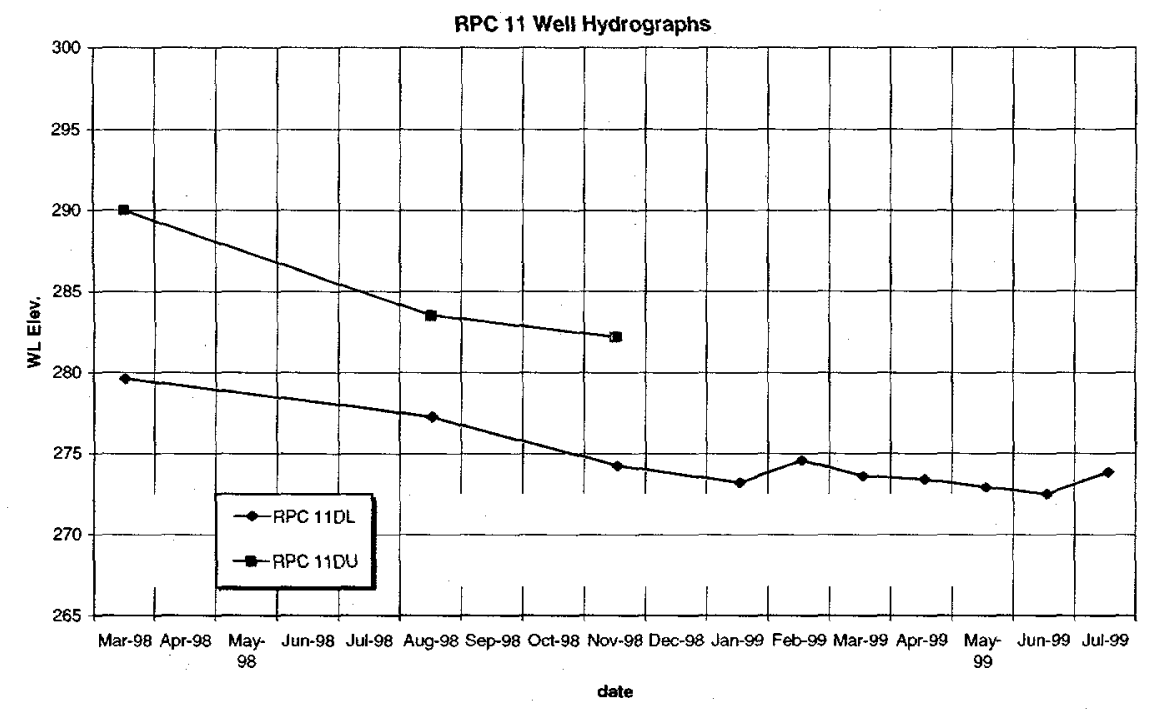

